\title{
PERSPECTIVAS PARA O MELHORAMENTO DE IINHAGENS HOMOZIGÓTICAS DE SOJA, COM ÊNEASE EM PRODUÇÃO DE GRÃOS E TEOR DE PROTEÍNA
}

\author{
LUÍS CLÁUDIO PRADO \\ Engenheiro agrônomo \\ Orientador: Prof. Dr. ISAIAS OLIVIO GERALDI \\ Dissertação apresentada à Escola \\ Superior de Agricultura "Luiz de \\ Queiroz", da Universidade de São \\ Paulo, para obtenção do título de \\ Mestre em Agronomia, Área de \\ Concentração: Genética e Melho- \\ ramento de Plantas.
}

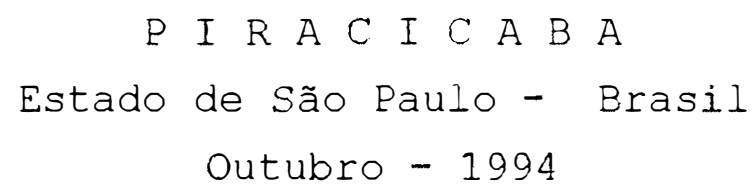




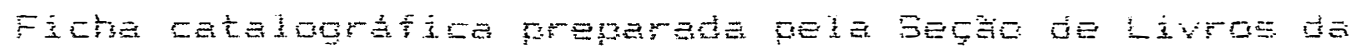

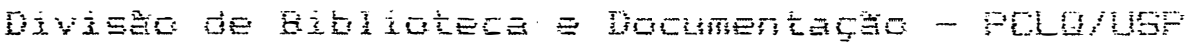

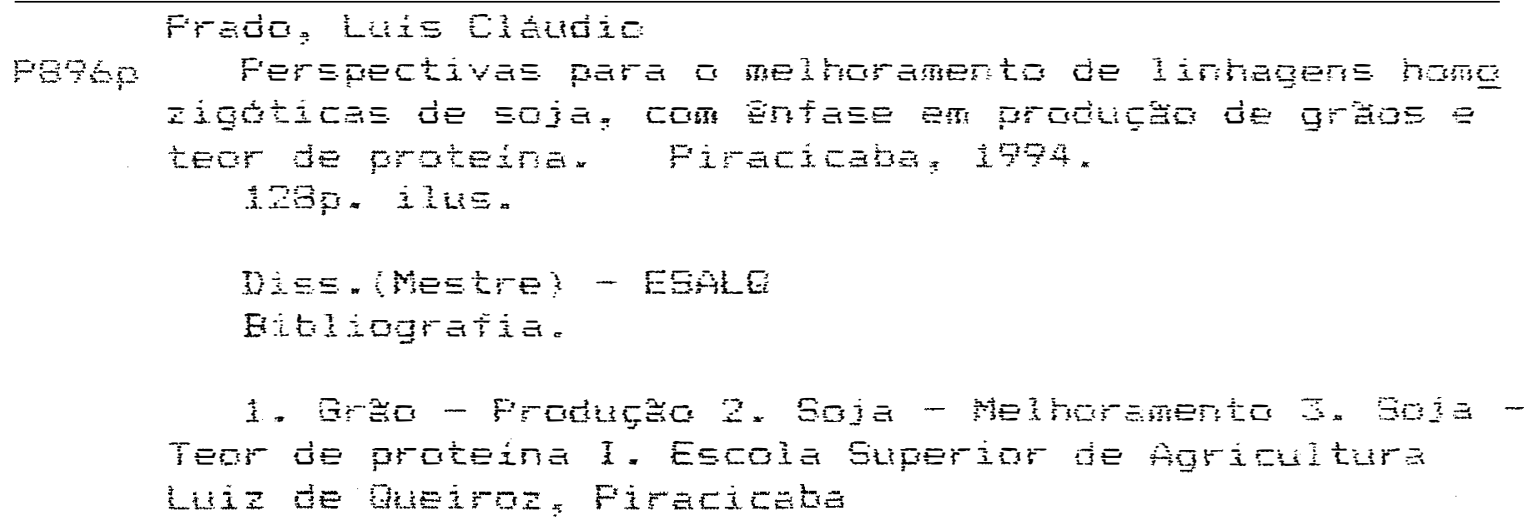




\section{PERSPECTIVAS PARA O MELHORAMENTO DE LINHAGENS HOMOZIGÓTICAS DE SOJA, COM ÊNEASE EM PRODUÇÃO DE GRÃOS E TEOR DE PROTEÍNA}

LUÍS CLÁUDIO PRADO

Aprovada em: 14/12/94

Comissão Julgadora:

Prof. Dr. Isaias Olívio Geraldi

ESALQ/USP

Prof. Dr. Natal Antonio Vello

ESALQ/USP

Dr. José Francisco Eerraz de Toledo

CNPSO/EMBRAPA

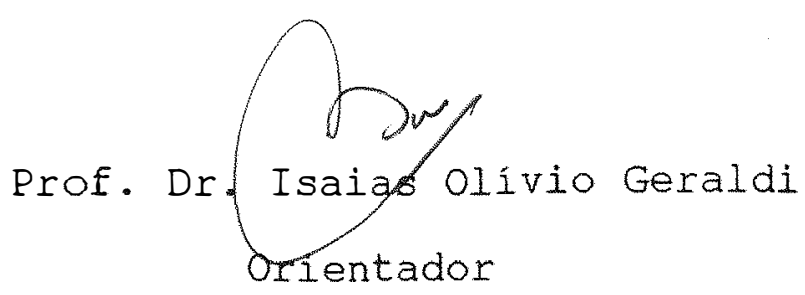


aos meus irmãos,

Júnior e Luís Antônio

OFEREÇO

Aos meus pais,

Carlos Alberto Prado e

Maria Lúcia Borges Prado 


\section{AGRADECIMENTOS}

- À Deus pela força, fé e presença constante.

- Ao Prof. Dr. Isaias Olívio Geraldi pela amizade, orientação, confiança, apoio e colaboração neste trabalho.

- À CAPES pela bolsa de estudos fornecida no período de março de 1992 a agosto de 1994.

- Ao Prof. Dr. Cláudio Lopes de Souza Júnior pela atenção dispensada durante a ausência do orientador.

- Ao Prof. Dr. Natal Antonio Vello e equipe pelo apoio na condução dos trabalhos que geraram esta pesquisa durante o afastamento do orientador.

- Aos professores do Departamento de Genética da ESALQ/USP, pelos ensinamentos e atenção.

- Ao Conselho Nacional de Desenvolvimento Científico e Tecnológico (CNPq) e ao Centro Nacional de Pesquisa de Soja (EMBRAPA) pelo apoio financeiro na fase inicial deste programa.

- Aos funcionários do Laboratório de Soja, José Roberto Alonso e Osmair José da Silva; pelo apoio, amizade e dedicação na realização dos trabalhos de campo e de laboratório. 
- Às funcionárias da Biblioteca do Departamento de Genética da ESALQ, Silvana Marchizelli Gregório e Aparecida Elisabeth Santos da Silva pela atenção, amizade e presteza.

- Aos funcionários e colegas do Departamento de Genética que contribuíram para que este trabalho fosse completado.

- Ao amigo Nelson da Silva Eonseca Júnior pela constante preocupação e ajuda na realização das análises estatísticas.

- Aos meus pais Carlos Alberto Prado e Maria Lúcia Borges Prado pelo carinho, paciência, estímulo e apoio indispensável, o qual tornou possível a realização deste curso.

- Aos amigos de República, Hélio Spinelli Cintra, Leonardo Pires Ramos e Marcelo Luiz Manna de Souza Melo pela amizade, apoio e paciência.

- Aos amigos do Curso de Pós-graduação que dividiram comigo alegrias e tristezas.

- À todas amigas pelo apoio direto ou indireto para a realização deste trabalho. 


\section{$S U M A ́ R I O$}

Páginas

RESUMO $\quad \ldots \ldots \ldots \ldots \ldots \ldots \ldots \ldots \ldots \ldots \ldots \ldots \ldots \ldots \ldots$

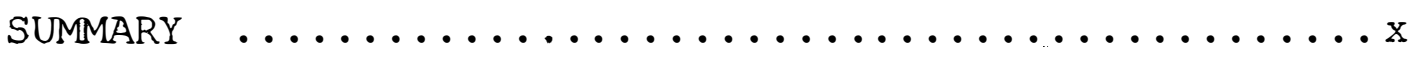

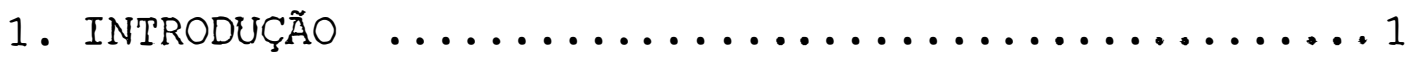

2. REVISÃO DE LITERATURA $\ldots \ldots \ldots \ldots \ldots \ldots \ldots \ldots \ldots \ldots \ldots \ldots \ldots \ldots \ldots$

2.1 Aspectos quantitativos $\ldots \ldots \ldots \ldots \ldots \ldots$

2.1 .1 Herdabilidades $\ldots \ldots \ldots \ldots \ldots \ldots \ldots$

2.1.2 Correlações genéticas ...............11

2.2 Melhoramento para teor de proteína em

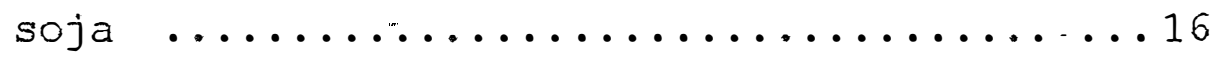

2.3 Método do SSD (Single Seed Descent) ......25

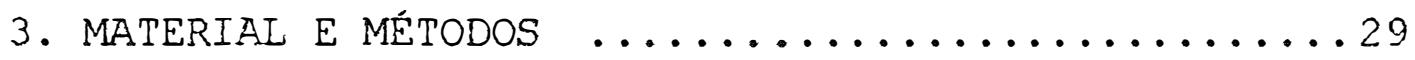

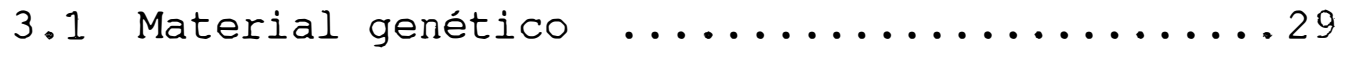

3.2 Caracterização do ambiente ................31

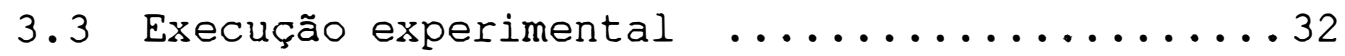

3.3.1 Método de melhoramento ..............32

3.3.2 Delineamento e caracteristicas do experimento $\ldots \ldots \ldots \ldots \ldots \ldots$ 
3.3.3 Caracteres avaliados ..............35

3.3.4 Análises de variância ............37

3.3.5 Estimativas dos componentes de variância e dos parâmetros derivados .....4I

3.3.6 Análise de covariância e cálculo dos coeficientes de correlação genética . . 42

3.3.7 Progresso esperado com seleção entre linhagens .................. 45

3.3.8 Precisão das estimativas $\ldots \ldots \ldots \ldots 46$

4. RESULtAdOS E DISCUSSÃO $\ldots \ldots \ldots \ldots \ldots \ldots \ldots$ 4.1 Análise de variância $\ldots \ldots \ldots \ldots \ldots \ldots \ldots \ldots$

4.2 Análises genéticas $\ldots \ldots \ldots \ldots \ldots \ldots \ldots \ldots 6$

4.2 .1 Produção de grãos $\ldots \ldots \ldots \ldots \ldots \ldots \ldots 56$

4.2.2 Teor de proteína ...............58

4.2 .3 Teor de óleo $\ldots \ldots \ldots \ldots \ldots \ldots \ldots \ldots 6 . \ldots 6$

4.2.4 Altura da planta na maturação .......62

4.2 .5 Número de dias para a maturação ......64

4.2 .6 Acamamento ................66

4.2.7 Número de dias para o florescimento . .667

4.2.8 Altura da planta no florescimento ....669

4.3 Correlação entre caracteres ...........71

4.4 Análise final dos dados ............76

5. CONCLUSÕES $\ldots \ldots \ldots \ldots \ldots \ldots \ldots \ldots \ldots \ldots \ldots \ldots \ldots \ldots \ldots \ldots$

REFERÊNCIAS BIBLIOGRÁFICAS $\ldots \ldots \ldots \ldots \ldots \ldots$

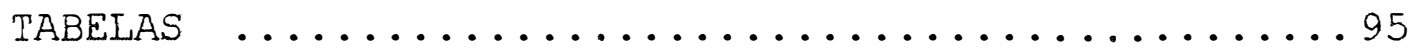




\title{
PERSPECTIVAS PARA O MELHORAMENTO DE LINHAGENS HOMOZIGÓTICAS DE SOJA, COM ENFASE EM PRODUÇÃO DE GRÃOS E TEOR DE PROTEÍNA
}

\author{
Autor: LUÍS CLÁUDIO PRADO \\ Orientador: Prof. Dr. ISAIAS OLÍVIO GERALDI
}

\section{RESUMO}

No melhoramento da soja [Glycine max (L.) Merrillj tem sido dada ênfase, principalmente, a caracteres como produção de grãos e outros de interesse agronômico. Pouca ênfase tem sido dada ao teor de proteina, embora este seja um dos principais produtos extraidos da soja, sendo esta, ainda a espécie cultivada que apresenta o maior teor de proteina.

o objetivo deste trabalho foi a avaliação de quatro cruzamentos biparentais de soja em gerações avançadas $\left(F_{8}\right)$, conduzidas pelo método SSD, visando a seleção de genótipos superiores para teor de proteína e produção de grãos simultaneamente e, paralelamente, realizar estudos básicos baseados na estimação de parâmetros genéticos e fenotípicos com intuito de estabelecer estratégias para $\circ$ melhoramento conjunto dos dois caracteres.

Para os quatro cruzamentos foram realizados experimentos em blocos ao acaso com três repetições de 360 
linhagens $F_{8}$; dois cruzamentos foram representados por 100 linhagens e os outros dois por 80 linhagens cada um. Os experimentos foram conduzidos em Piracicaba (SP), com latitude $22^{\circ} 42^{\prime} \mathrm{S}$, longitude $47^{\circ} 38^{\prime} \mathrm{O}$ e altitude $537 \mathrm{~m}$. Avaliaram-se os caracteres produção de grãos (PG), teor de proteína (TP), teor de óleo (TO), número de dias para o florescimento (DF), altura da planta no florescimento $(A F)$, número de dias para a maturação (DM), altura da planta na maturação (AM) e acamamento (AC).

o caráter produção de grãos apresentou em três dos quatro cruzamentos, médias superiores a das cinco testemunhas, indicando a possibilidade de progresso com seleção em todos os quatro cruzamentos.

Os quatro cruzamentos exibiram ainda alta variabilidade para a maioria dos caracteres, com exceção do número de dias para a maturação (DM) e teor de proteína (TP). Para a produção de grãos, obtiveram-se coeficientes de herdabilidade entre médias de linhagens da ordem de 508 e, conseqüentemente, estimativas de progressos esperados da ordem de 30\%, com $10 \%$ de intensidade de seleção, nos quatro cruzamentos. Para o teor de óleo, o coeficiente de herdabilidade foi da ordem de 708, com exceção de um cruzamento (468), possibilitando, também, a obtenção de progressos substanciais com seleção. Para teor de proteína foi possível a obtenção de estimativa com boa precisão de herdabilidade em apenas um cruzamento; novamente, a 
herdabilidade foi alta (61\%), e, conseqüentemente, 0 progresso esperado com seleção também foi alto.

As correlações genéticas aditivas foram discrepantes entre os diferentes cruzamentos, indicando a necessidade de diferentes procedimentos para cada cruzamento. O cruzamento $I$ (OC-79230 X BR-80-8858) mostrou-se apropriado para o melhoramento simultâneo para produção de grãos e teor de proteína. Os cruzamentos 3 e 4 (BR-80-14853 X PI-165896 e $\mathrm{BR}-80-14853$ _ X PI-239235) mostraram-se apropriados para $\bigcirc$ melhoramento simultâneo para produção de grãos e teor de óleo. Finalmente, o cruzamento 2 (BR-80-8858 X BR-80-14853) mostrou-se apropriado somente ao melhoramento para produção de grão. Evidentemente, os demais caracteres agronômicos, também devem ser levados em conta no processo de seleção. 
Breeding perspectives of soybean inbred lines for seed yield and protein content

\author{
Author: LUÍS CLÁUDIO PRADO \\ Adviser: Prof. Dr. ISAIAS OLÍVIO GERALDI
}

\title{
SUMMARY
}

The main priorities in soybean [Glycine max (L.) Merrill] breeding programs has been seed yield and others traits as lodging, plant height, disease and insect resistance. Protein content has almost not been considered, although soybeans has the highest protein content among the crop species.

Four single crosses of soybeans at F7:8 $_{7}$ generation were evaluated for seed yield, protein content, oil content and other traits. The main objectives were the estimation of genetic and phenotypic parameters aiming the selection for seed yield and protein content, simultaneously.

Evaluation trials were carried out at Piracicaba (SP) in 1993/94 at latitude $22^{\circ} 42^{\prime}$ ', longitude $47^{\circ} 38^{\prime} \mathrm{W}$ and altitude 537m. Material used comprised 100 random inbred lines for crosses OC-79230 X BR-80-8858 and BR-80-8858 X BR-80-14853, and 80 random inbred lines for crosses BR-80-14853 X PI-165896 and BR-80-14853 X PI239235. The entries plus the checks were evaluated in 
a completely randomized block design with three replications for each cross.

Three out four crosses showed higher yields than the checks. High genetic variability was observed for most of the traits, except for days to maturity. Consequently, the coefficients of heritability were very high for most of traits; $i$. e., on the average, 538 for seed yield, 668 for oil content and 618 for protein content. Expected responses based on 108 of selection intensity were $28 \%, 38$ and 58 for the three traits, respectively.

The additive genetic correlation among traits were not consistent for different crosses. Thus, we suggest different procedures for the four populations, relative to the breeding for seed yield, protein content and oil content. For cross 1 (OC-79230 X BR-80-8858), selection for seed yield and protein content; for crosses 3 and 4 (BR-80-14853 X PI-165896 and BR-80-14853 X PI239235), selection for seed yield and oil content; and for cross 2 (BR-80-8858 X BR-80-14853), selection for seed yield, only. Obviously, other traits, such as lodging, days at maturity, plant height, etc need to be taking into account. 


\section{INTRODUÇÃO}

A soja cultivada [Glycine max (L.) Merrill] é uma das espécies mais importantes social e economicamente. Segundo $\circ$ Foreign Agricultural Service ${ }^{1}$, citado por FEHR (1987), a soja é responsável por 608 do suprimento de proteína de origem vegetal no mundo e 308 do óleo. A proteína é utilizada principalmente para a formulação de concentrados para alimentação animal, mas também, é utilizado em vários produtos industriais.

Nos longos anos de melhoramento da soja, têmse levado em conta, principalmente, a produção de grãos e outros caracteres agronômicos, ficando o caráter teor de proteína relegado a um segundo plano. Como normalmente há correlação negativa da produção de grãos e do teor de óleo com teor de proteína, este caráter tem mostrado tendência de decréscimo, na medida em que cultivares antigos são substituídos por cultivares modernos mais produtivos.

1 Foreign Agricultural Service, 1985. Foreign agricultural circular FOP-1-85, USDA, Washington, D.C. 
Tem havido crescente interesse em aumentar $\circ$ teor protéico da semente (em torno de 408), a patamares superiores (em torno de até 50\%, baseado em genótipos não adaptados), bem como, reduzir sua pobreza em aminoácidos sulfurados, como a metionina e cistina.

Com a crescente carência alimentar pela qual passa o mundo, há a necessidade de se fornecer alimentos com alto teor de proteína, a baixo custo e de boa qualidade. A soja encaixa-se muito bem neste quadro, pois é a espécie cultivada que apresenta $\circ$ maior teor de proteína. Isto mostra que é importante nos trabalhos de melhoramento, o desenvolvimento de cultivares com alto teor de proteína.

Atualmente o Brasil ocupa posição de destaque na produção mundial. Em 1940/41, a soja no Brasil atingiu uma produção de 457 toneladas em uma área de 702 ha, com uma produtividade de $651 \mathrm{~kg} / \mathrm{ha}$ (Bonato ${ }^{2}$, citado por MOREIRA, 1992). No período de 1387 a 1992, a soja, no Brasil, apresentou certa instabilidade na área colhida, na produção de grãos e, consequientemente, na produtividade média. Em 1987 foram colhidos $9.134 \mathrm{mil}$ ha; em 1989, $12.211 \mathrm{mil}$ ha e em 1992, $9.419 \mathrm{mil}$ ha. A produção total

\section{BONaTO, E.R. \& BONaTO, A.I.Y. A soja no Brasil: história e} estatística. Iondrina, EMBRAPA - CNPSo, 1987. 61P. (Documento, 21). 
foi de 16.969 mil toneladas em 1987, $24.071 \mathrm{mil}$ toneladas em 1989 e de $19.161 \mathrm{mil}$ toneladas em 1992. As produtividades médias em 1987, 1989 e 1992, foi de 1.858, 1.971 e $2.034 \mathrm{~kg} / \mathrm{ha}$, respectivamente (FÃO Production Yearbook, 1988 a 1993). Apesar da flutuação, a soja permaneceu em segundo lugar entre as espécies vegetais mais importantes, no Brasil, perdendo apenas para o milho.

Observando estas produções, só em 1992, o Brasil produziu 7.664 mil toneladas de proteína. Se o teor de proteína dos cultivares fosse aumentado em dois pontos percentuais, 0 Brasil poderia produzir $384 \mathrm{mil}$ toneladas de proteína a mais, um valor adicional considerável, sem aumentar a área ou os custos de produção.

Este trabalho integra o Programa de Soja do Setor de Genética Aplicadas às Espécies Autógamas do Departamento de Genética da Escola Superior de Agricultura "Luiz de Queiroz", da Universidade de São Paulo, que entre seus objetivos visa desenvolver novos genótipcs de soja com alto teor de proteína e alta produção de grãos, para utilização em plantios comerciais e, também, utilização destes em programas de melhoramento. Basicamente, os objetivos do presente trabalho compreendem os seguintes aspectos:

a. Avaliação de quatro cruzamentos biparentais de soja em gerações avançadas $\left\{F_{8}\right\}$, conduzidas pelo método SSD, 
visando a seleção de genótipos superiores para teor de proteína e produção de grãos simultaneamente;

b. Fazer estudos básicos de estimação de parâmetros genéticos e fenotípicos com $\circ$ intuito de estabelecer estratégias para o melhoramento conjunto para ambos os caracteres, bem como outros de interesse agronômico e econômico. 


\section{REVISÃO DE LITERATURA}

Os trabalhos de melhoramento genético de qualquer espécie vegetal devem estar alicerçados no conhecimento detalhado de suas características botânicas e agronômicas e respectivo controle genético, bem como, principalmente, nas informações sobre natureza e quantidade da variabilidade genética disponível para cada caráter importante. Disso depende a escolha acertada de parentais e do método de melhoramento mais eficiente (VERNETTI, 1983).

Nesta revisão são relatados três tópicos considerados essenciais para a abordagem do assunto em questão, lastreada por trabalhos e opiniões de diversos pesquisadores. Os tópicos são os seguintes: 1. Aspectos quantitativos; 2. Melhoramento para teor de proteina em soja e 3. Método SSD (Single Seed Descent).

\subsection{Aspectos quantitativos}

$\begin{aligned} 0 & \text { estudo e entendimento dos caracteres } \\ \text { quantitativos } & \text { representam interesse primário para o }\end{aligned}$


melhorista. Os caracteres quantitativos têm sido estudados desde o início da genética em soja, com o objetivo de encontrar um método mais eficiente de melhoramento e de seleção.

Estimativas da variância genética aditiva, do coeficiente de herdabilidade, do progresso esperado com seleção e correlações genéticas entre caracteres como produção de grãos, teor de proteína, teor de óleo, altura da planta, acamamento e número de dias para maturação são importantes, sendo utilizados efetivamente em programas de melhoramento de plantas.

BRIM \& COCKERHAM (1961) e CROISSANT \& TORRIE (1971) observaram que a variância genética aditiva foi o principal componente da variância genética para todas as características de importância econômica.

ISHIGE (1984) encontrou que os efeitos dos genes aditivos foram mais importantes para o teor de proteína que os efeitos de dominância e epistasia.

Uma análise foi feita por MCKENDRY et al. (1985), para investigar a herdabilidade do teor de proteina nas sementes em dois cruzamentos biparentais de soja. Observaram que os efeitos aditivos e dominantes foram significativos em ambos os cruzamentos. A dominância 
pareceu estar direcionando o decréscimo do teor de proteína.

\subsubsection{Herdabilidade}

Herdabilidade é usualmente definida como uma parte da variância total ou fenotípica de um dado caráter, que é estritamente devido à variação genética.

HANSON (1963) estabelece que a estimativa da herdabilidade tem duas finalidades no melhoramento genético: a primeira, mostra com que facilidade diferentes características são selecionadas sobre um determinado método de seleção; e a segunda, visa a obtenção de estimativas com a finalidade de predizer ganhos com seleção.

DUDLEY \& MOLL (1969) relataram que cada estimativa de herdabilidade no melhoramento de plantas diz respeito especificamente à população de genótipos para a qual foi estimada. Também, cada estimativa refere-se ao conjunto particular de ambientes e condições experimentais na qual os genótipos foram testados.

Os principais caracteres em soja apresentam altos coeficientes de herdabilidade, exceto a produção de 
grãos que apresenta valores de herdabilidade de menor magnitude.

JOHNSON et al. (1955a) encontraram o valor do coeficiente de herdabilidade para produção de grãos igual a 0,35. Valor menor desta herdabilidade foi encontrada por KWON \& TORRIE (1964). Um outro estudo realizado por SHANNON et al. (1972) mostrou uma ampla variação do cooficiente de herdabilidade para produção de grãos, de 0,16 a 0,73

O coeficiente de herdabilidade do caráter teor de proteína foi estudado por JOHNSON et al. (1955a), que encontraram $\circ$ valor desta herdabilidade igual a 0,60. KWON \& TORRIE (1964) encontraram este valor igual a 0,57. FEHR ¿ WEBER (1968) e SMITH \& WEBER (1968) obtiveram, valores ainda maiores, da ordem de 0,77 e 0,88, respectivamente.

Entretanto, outros estudos mostraram uma considerável variação de resultados para os coeficientes de herdabilidade para teor de proteína; SHANNON et al. (1972) encontraram uma amplitude de 0,81 a 0,92, enquanto que, BRIM \& BURTON (1979) obtiveram uma oscilação de 0,20 a 0,37. Como pode-se observar, o coeficiente de herdabilidade para o caráter teor de proteína apresenta uma ampla gama de variação.

Os altos valores de herdabilidade do caráter teor de proteína encontrados por THORNE \& FEHR (1970), em 
torno de 90,68, sugerem que linhagens com altos teores de proteína podem ser selecionados a partir de populações envolvendo parentais exóticos.

Em populações derivadas de um cruzamento entre dois parentais com baixo tenr de proteína e um outro cruzamento entre uma linhagem com alto teor de proteína e outra com baixo teor, SHORTER et al. (1976) encontraram estimativas de herdabilidade para este caráter iguais a 708 e 868, respectivamente, para os dois cruzamentos.

Em seis estudos envolvendo 13 populações de linhagens tomadas ao acaso de cruzamentos biparentais e triplos, as estimativas de herdabilidade no sentido amplo para teor de proteína variaram de 398 a 928. A herdabilidade média para populações de cruzamentos entre linhagens adaptadas com média de porcentagem de proteína inferior a 428 foi de 718. A herdabilidade média para teor de proteína foi de 828 para populações oriundas de linhagens adaptadas onde um ou mais parentais tinham acima de 428 de proteína. Havia, também, dez populações que tinham germoplasma exótico (Glycine Max ou G. soja) na sua constituição; a herdabilidade média para teor de proteína nestas populações foi de 838 (BURTON, 1984).

JOHNSON et al (1955a) encontraram o coeficiente de herdabilidade para o teor de óleo da ordem de 0,70 . Segundo os estudos realizados pelos seguintes 
autores: BRIM et al. (1959), KWON \& TORRIE (1964), FEHR \& WEBER (1968), SMITH \& WEBER (1968) E BURTON \& BRIM (1981), os valores dos coeficientes de herdabilidade do teor de óleo oscilaram entre 0,28 e 0,89 .

\section{JOHNSON \& BERNARD (1963) organizaram uma} tabela de herdabilidades (em o) de alguns caracteres, quando a unidade de seleção são plantas $F_{2}$ e médias de $F_{4}$ ou linhas de geiações mais avançadas $\left(\overline{F_{n}}\right)$. A seguir, a tabela adaptada:

Unidade de seleção

Caráter

$\hat{h}^{2}\left(p_{2}\right)$

Produção de grãos 5 38

Teor de proteína 25

63

Teor de óleo 30 $-67$

(1) $: n \geq 4$

Estimativas de herdabilidades têm grande utilidade para obtenção da estimação do progresso genético esperado com seleção. Até meados da década de 50, as estimativas de herdabilidades não estavam sendo utilizadas com esta finalidade (JCHNSON et al., 1955a). 


\subsubsection{Correlações genéticas}

o conhecimento das correlações entre os caracteres é de relevante importância no melhoramento de plantas. Quando se pratica seleção em um caráter é importante saber como os demais são alterados indiretamente (FALCONER, 1989). Pode-se, se a correlação entre dois caracteres for alta, selecionar um caráter e obter a resposta no outro, principalmente, se este segundo caráter apresentar dificuldade de seleção e/ou baixa herdabilidade.

As correlações de muitos pares diferentes de caracteres têm sido estimadas, mas aqui é dado atenção especial às correlações envolvendo os três mais importantes caracteres para este trabalho, isto é, produção de grãos, teor de proteína e teor de óleo.

Produção de grãos e teor de proteína apresentam, normalmente, correlações genéticas negativas. Portanto, a seleção para um resulta no declínio do outro. Entretanto, esta correlação não tem sido muito consistente.

JOHNSON et al. (1955a), KWON \& TORRIE (1964) e JOHNSON \& BERNARD (1963), encontraram correlação genética entre produção de grãos e teor de proteína, da ordem de $0,64,-0,58$ e $-0,20$, respectivamente. Entretanto, através 
de outros estudos, diversos autores encontraram uma ampla variação da correlação genética entre estes dois caracteres: $r=0,35$ a $-0,55$ (BYTH et al., 1969b), $r=0,54$ a $-0,74$ (SIMPSON \& WILCOX, 1983) e $r=-0,33$ a $-0,65$ (HOLBROOK et al., 1989).

Ao contrário, do que normalmente ocorre, alguns autores mencionam a presença de correlação genética positiva entre produção de grãos e teor de proteína, como alguns já citados anteriormente.

$$
\text { Monteverde } 3 \text {, citado por BURTON (1989), }
$$

observou correlações genéticas positivas com valões iguais a $0,50,0,33$ e 0,59 entre produção de grãos e teor de proteína, em três grupos de linhagens $E_{3}$ derivadas do cruzamento entre a cultivar 'Roanoke' e três linhagens que foram relativamente superiores em teor de proteína e produção de grãos.

$$
\text { SHANNON et al. (1972) estudaram seis }
$$

populações de soja derivadas do cruzamento de quatro linhagens, sendo duas de alto teor de proteína e duas de alta produção de grãos. Os valores das correlações

3 MONTEVERDE, E. Phenotypic and genotypic correlations between yield, protein and oil contents and others caracters in soybean (Glycine Mas'). Revista de Facultad de Agronomia. Universidad Central de Venezuela 13: 183-214. 1984. 
genéticas entre produção, proteína e óleo estão apresentadas no quadro a seguir. Entre outros aspectos, constatou-se que nas populações derivadas de alguns cruzamentos não havia correlação entre teor de proteína e produção de grãos, indicando a possibilidade de seleção de genótipos superiores para estes dois caracteres.

Correlações Genéticas

Populações

TP X PG

TP X TO

PG X TO

Prot. $1 \mathrm{X}$ Prot. 2

$-0,28$

$-0,64$

0,24

Prot. 1 X Prod. 1

$-0,62$

Prot. $1 \mathrm{X}$ Prod. 2

$-0,07$

$-0,92$

0,07

Prot. 2 X Prod. 1

$-0,05$

$-0,46$

0,21

Prot. $2 \mathrm{X}$ Prod. 2

$-0,55$

$-0,57$

0,08

Prod. $1 \mathrm{X}$ Prod. 2

0,61

$-0,62$

$-0,08$

A ampla gama de correlações genéticas entre teor de proteina e produção de grãos, citadas 'na literatura, indicam ser possivel o desenvolvimento de cultivares com alta produção de grãos e com alto teor de proteína (BURTON, 1984).

A correlação genética entre produção de grãos e teor de óleo, tem sido observada como positivas ou 
nulas. KWON \& TORRIE (1964) encontraram para esta correlação um valor igual a 0,07, enquanto que, BYTH et al. (1969b) observaram uma variação na magnitude da correlação genética para estes dois caracteres, entre 0,45 a $-0,03$.

A correlação genética negativa entre teor de óleo e teor de proteína tem sido observada por vários pesquisadores.

HANSON et al. (1961a), JOHNSÖN\& BERNARD (1963), KWON \& TORRIE (1964), HARTWIG (1969) e MILLER \& EEHR (1979) encontraram, respectivamente, correlação genética de $-0,54,-0,60,-0,66,-0,80$ e $-0,66$ entre teor de óleo e teor de proteina. Outros autores encontraram uma ampla oscilação dos valores da correlação entre estes dois caracteres: $r=-0,26$ a $-0,74$ (WEISS et al., 1952), $r=$ 0,48 a $-0,70$ (JOHNSON et al., 1955b), $r=-0,65$ a $-0,77$ (HARTWIG \& COLLINS, 1962) e $r=-0,15$ a $-0,96$ (SIMPSON \& WILCOX, 1983)

LAM-SÁNCHEZ et al. (1989) trabalhando no Brasil, encontraram uma correlação genética negativa entre teor de proteína e teor de óleo da ordem de -0,24.

Os estudos realizados por KROBER \& CARTTER (1962) indicam que um aumento no teor de proteina, 
geralmente significa a redução de 1,6 a 2 vezes esse valor, no teor de óleo.

Os estudos realizados por SEBERN \& LAMBERT (1984) sintetizados no quadro abaixo, indicam a dificuldade do desenvolvimento de um cultivar com alta produção de grãos e também, com alto teor de proteína e de óleo.

CORRELAÇÕES GENÉTICAS

Geração

TP X PG

TP X TO

PG X TO

$\underline{\text { População A }}$

$\begin{array}{llll}F_{4} & -0,23 & -0,44 & -0,39 \\ F_{6} & -0,58 & -0,18 & -0,02\end{array}$

População B

$\begin{array}{llll}F_{4} & -0,25 & -0,11 & 0,29 \\ F_{6} & -0,47 & -0,20 & 0,17\end{array}$

A densidade de sementes de soja, foi muito utilizada para a seleção de genótipos com altos teores de proteína e óleo. SMITH \& WEBER (1968) encontraram correlações genéticas entre densidade de sementes e teor de proteína e teor de óleo, da ordem de 0,70 e - 0,99, respectivamente. 
Segundo EEHR \& WEBER (1968), as correlações genéticas entre densidade de sementes e teor de proteína e densidade de sementes e teor de óleo foram de 0,18 e 0,38 , respectivamente.

Há poucos trabalhos realizados, relacionando produção de grãos e, principalmente, teor de proteína, para as condições brasileiras. Portanto, a obtenção de informações a respeito da correlação entre estes dois caracteres é de fundamental importância para a condução de trabalhos de melhoramento.

\subsection{Melhoramento para teor de proteína em soja}

Os cultivares atualmente recomendados para plantio no Brasil foram selecionados principalmente para produção de grãos e teor de óleo. Como estes dois caracteres são normalmente negativamente correlacionados com o teor de proteína, como já foi mencionado anteriormente, este tem-se mantido em niveis baixos (em torno de 40\%), em comparação com o teor potencial (em torno de 508) nos materiais não adaptados.

É esperado que as cultivares futuras de soja, tenham uma maior porcentagem de proteina que as cultivadas atualmente. Entretanto, em adiçăo ao maior teor de proteina, estas cultivares precisam ser tão ou mais 
produtivas, e ter adequadas resistências às doenças e condições ambientais adversas (HARTWIG, 1969).

É muito importante a uniformização das amostras de sementes de soja onde serão realizadas as análises do teor de proteína e teor de óleo. CoLLINS \& CARTTER (1956) e BRIM et al. (1967) encontraram que as sementes da metade inferior das plantas de soja continham significativamente menos proteina e mais óleo que as sementes da metade superior.

Os métodos de melhoramento empregados para aumentar o teor de proteína em soja têm utilizados cruzamentos entre plantas introduzidas com altos teores de proteina e cultivares adaptados com altos rendimentos de grãos.

o conhecimento do desempenho dos parentais é importante para o desenvolvimento de populações para seleção de linhagens para alto teor de proteína e óleo.

Introduções de plantas com altos teores de proteína têm sido desejáveis nas coleções de soja mundiais. Estas são, normalmente, denominadas de linhagens exóticas, podendo ser úteis como fonte de variabilidade.

THORNE \& EEHR (1970) estudaram germoplasmas exóticos com alto teor de proteína como fonte de variabilidade para proteína e óleo, em populações de soja 
derivadas de cruzamentos simples (adaptado X exótico) e cruzamentos triplos [(adaptado X exótico) X cultivar com alto teor de proteína]. Os cruzamentos triplos produziram maior número de linhagens superiores para proteína e óleo que os cruzamentos duplos, refletindo a influência dos genes para alta proteína da cultivar.

Segundo SHANNON et al. (1972), o progresso tem sido lento no desenvolvimento de linhagens com características agronômicas desejáveis e produção de grãos a partir de variedades cruzadas com plantas introduzidas com alto teor de proteína. Isto pode ser devido a correlação negativa entre produção de grãos e teor de proteína ou simplesmente, devido a maior dificuldade de combinação favorável dos genes afetando ambas características.

Uma estratégia possivel para desenvolver cultivares com alta produção de grãos e alto teor de proteina é a transferência de genes responsáveis pela alta concentração de proteína para cultivares com alta produção de grãos, via retrocruzamento.

HARTWIG \& HINSON (1972) realizaram 0 retrocruzamento de uma linhagem não-adaptada com alto teor de proteina e o cultivar 'Bragg' como parental recorrente. Selecionado para baixo teor de óleo obtiveram uma linhagem na segunda geração de retrocruzamento a qual, comparada 
com 'Bragg', foi 108 superior em teor de proteina e apenas 3,58 menos produtiva.

Após dois ciclos de retrocruzamentos de uma planta introduzida com alto teor de proteína para três diferentes parentais recorrentes com alta produção de grãos; 158,228 e $19 \%$ das linhagens foram significativamente superiores para proteína e não significativamente diferentes para produção de grãos em relação aos três parentais recorrentes (WEHRMANN et al., $1987)$

CAPUNO (1986) comparou o cruzamento biparental e o retrocruzamento para aumentar a produção de grãos da 'Vinton 81' tentando manter o teor de proteína constante a nivel moderadamente alto. Três cultivares de alta produção foram utilizados como parentais recorrentes. Quando linhagens $F_{5}$ dos cruzamentos biparentais e linhagens $R_{1} F_{4}$ foram avaliadas com os parentais, apenas duas linhagens dos cruzamentos simplès e nenhuma dos retrocruzamentos foram superiores em produção e igual ao teor de proteína da 'Vinton 81'.

A seleção recorrente não é normalmente utilizada em culturas autógamas, principalmente a soja, devido ao custo associado aos cruzamentos de progênies de plantas selecionadas e o baixo número de sementes produzidas por cruzamento. 
Uma redução na produtividade de grãos em genótipos com alto teor de proteína seria considerada consistente com a correlação genética negativa entre teor de proteína e produção de grãos, já notificada por vários autores. Entretanto, BRIM (1963) não observou redução na produção de grãos, mas um aumento no teor de proteína, após quatro ciclos de seleção recorrente para alto teor de proteína em uma população de soja.

Programas de seleção recorrente têm tido aplicações limitadas no melhoramento de soja. BRIM \& STUBER. (1973) descreveram um método de seleção para a soja que elimina a polinização manual.

BRIM \& BURTON (1979) obtiveram sucesso no aumento do teor de proteína em sementes de soja, sem uma redução significativa na produção de grãos, utilizando dois ciclos de seleção recorrente. Estes sugerem uma estratégia viável para aumentar o teor de proteína sem a conseqüente redução do rendimento de grãos, onde realizase dois ou três ciclos de seleção recorrente para teor de proteína seguida de um ciclo de seleção recorrente para produção de grãos.

A seleção recorrente oferece consideráveis promessas como um método efetivo de melhoramento para caracteres econômicos (KENWORTHY \& BRIM, 1979). 
MILLER \& EEHR (1979) avaliaram a eficácia da seleçãc recorrente para teor de proteina em soja via seleção direta para teor de proteina e seleção indireta para baixo tecr de óleo, e concluiram que a seleção indireta poderia ser utilizada para aumento do teor de proteina em soja, mas seria consideravelmente menos eficiente que a seleção direta.

Usando a seleção recorrente, para aumentar o teor de proteina, entre progenies $S_{1}$ de uma populaça derivada do cruzamento de 12 linhagens para aita concentraça de proteina com 12 linhagens para alto rendimento de grãos, MILLER \& EEHR (1979) conseguiram aumentar em 3,48 a média da população original com um ciclo de seleção.

KENWORTHY \& BRIM (1979) observaram uma reduçãc significativa da produção de grãos após três ciclos de seleçãc recorrente para teor de proteina, e em apenas uma população, observaram a redução do teor le proteina após três ciclos de seleção recorrente para produção de grãos. Portanto, parece que o teor de proteína teve um maior efeito negativo scbre a produção de grãos que a situação inversa.

KELLY \& BIISS (1975), trabalhando com feijão, têm sugerido a seleção de familias para producão de grãos 
sequida por uma seleção individual dentro de familias para teor de proteina.

Através da seleção massal para alta e baixa densidade de sementes, realizada em duas populações de soja, SMITH \& WEBER (1968) observaram que quando selecionavam as sementes para alta densidade, o teor de proteina aumentava e o teor de óleo reduzia e, quando faziam a seleção para baixa densidade, o inverso ocorria.

Normalmente os melhoristas não acreditam na seleção precoce para aumentar o teor de proteina em soja, entretanto, SEBERN a LAMBERT (1984) observaram que a maioria das linhas testadas para teor de proteina estabilizaram-se em gerações iniciais, e encontraram uma significante correlação entre as gerações iniciais e gerações subseqüentes para teor de proteina, indicando que a seleção precoce de plantas ou linhas é aplicável.

EEHR \& WEBER (1968) realizaram três ciclos de seleção massal para tamanho de sementes e densidade de sementes e, demonstraram que o máximo progresso para teor de proteina ocorria quando selecionava-se sementes grandes e com alta densidade. A seleção de sementes pequenas e com baixa densidade resultou em máximo progresso para teor de óleo. 
A separação por densidade foi estudada por HARTNIG \& COLLINS (1952) a concluiram que a seleção de plantas com baixa densidade das sementes resultou em aumento da frequência de linhas com alto teor de óleo, por outro lado, selecionando plantas com alta densidade nas sementes, resultou em aumento na frequiencia de progênies com alto teor de proteina.

A densidade do óleo de soja é aproximadamente $0,93 \mathrm{~g} / \mathrm{cm}^{3}$ e a densidade da porção não oleosa da semente de soja é estimada entre 1,3 a $1,4 \mathrm{~g}^{\prime} \mathrm{cm}^{3}$. O óleo e a proteina juntos perfazem de 60 a 658 do pesa seco nas sementes de soja. Com base nas diferenças de densidades das porç̃̃es oleosas e não-oleosas das sementes, é posaivel classificar as sementes de plantas em populações segregantes, com base na densidade, e portanto, selocionar plantas com maior teor de proteina ou maior teor de óleo (HARTWIG, 1969 ).

Uma outra técnica utilizada para melhoramento do teor de proteína e demais caracteres agronômicos em soja é a utilização de seleção por índices. HAZEL (1943) sugeriu um método de construção de indices o qual proporcionava o máximo avanço na selecão. Na construção do indice, é necessário o conhecimento de trôs constantes (1) valor econômico relativo de cada caráter, (2) as variâricias genéticas e fenotipicas de cada carater e (3) 
as covariâncias genéticas e fenotipicas de cada par de caracteres.

BRIM et al. (1959) comparam indices onde vários pesos Foram atribuidos para teor de proteina e teor de oleo e, concluiram que a selerão simultânea para teor de proteina e produçăo de grăos foi equivaiente ou superior em valores econômicos em relação à seleça individual para teor de proteina.

KEMPTHORNE \& NODSKOG (1959) desenvolveram a teoria do indice de seleção onde o ganho genético é maximizado em um ou mais caracteres, enquanto o ganro genético restringe-se a zero em outro grupo de um ou mais caracteres.

OPENSHAW \& HADLEY (1984) examinaram a efetividade de vários indices de seieção destinados a aumentar a concentração de proteina da soja, mantendo a teor de óleo constantes.

o progresso tem sido lento, no desenvolvimento de cultivares com alta concentração de proteína e alta produção de grãos. Isto é devido à correlação genética negativa entre estes dois caracteres e a dificuldade de selecionar simultaneamente combinações com alto tecr de proteína e produção de grãos para o grande número de genes controlardo estes caracteres. O uso da seleção por indices 
restritos, parece ser o mais promissor método para aumento da produção de grãos e manter constante a alta concentração de proteína (HOLBROOK et al., 1989).

us trabalhos de pesquisa demonstram ser possivel o melhoramento para aumentar a quantidade e quaiidade da proteína da soja, sem sacrificar o desempenho dos caracteres agronômicos. Entretanto, é necessário incentivos econômicos neste sentido, visto que hoje, a importância é dada, prioritariamente à produção. Se aos produtores Éossem pagos um prêmio peìa produção de proteina, a demanda por cultivares com esta caracteristica seria aumentada e haveria uma pressão maior sobre os melhoristas por novos cultivares. No futuro, a soja, provavelmente será comercializada de acordo com sua constituição química (proteina e óleo\}, assim como, já ocorre com o trigo e a cana-de açúcar.

\section{3 Método SSD (Single seed Descent)}

O tamanho e número de populações que podem ser avaliados para determinados caracteres, assim como, os objetivos primários de un programa de melhoramento, são condições de interesse quando da escolha do método de melhoramento de plantas. 
O método SSD consiste no avanço rápido das gerações sem seleção natural e sem seleção artificial. O conceito de rápido avanço de gerações, alcançando a homozigose em quantas linhagens fosse possível, sem seleção, foi proposto por Goulden (1941), que não utilizou o termo "single seed descent" para descrever o seu processo, embora utilizando o termo "progenies of single plants" que não ficou consagrado (JENSEN, 1988).

A primeira citação na literatura do termo Single Seed Descent, para descrever o avanço rápido de um grande número de plantas $F_{2}$ até a geração $F_{5}$, sem a extração de linhagens, como um método de melhoramento em soja, foi feita por JOHNSON \& BERNARD (1962).

BRIM (1966) descreveu o método do SSD como sendo uma modificação do método genealógico e relata que a aplicação do SSD está diretamente ligada à predominância da variância genética aditiva para os caracteres em questão.

Segundo BRIGGS \& KNOWLES (1967), quando O melhorista está tentando retirar o máximo de um ou poucos cruzamentos em pouco tempo, o método genealógico é a melhor escolha. Entretanto, várias modificações do método de linhas puras do melhoramento de piantas têm sido aplicadas em plantas autógamas. 
EMPIG \& EEHR (1971) avaliaram O SSD em comparação com outros três métodos para avançar gerações de populações de soja hibrida, para suas habilidades em manter genótipos superiores e variabilidade genética para caracteres agronômicos e suas eficiências em tempo experimental. Eles encontraram que o SSD foi o método menos influenciado pela seleção natural e pode ser o mais útil método para certas condições, como casa de vegetação e avanço em outros locais no inverno, onde o genótipo exibe performance diferente das áreas de produção comercial.

BOERMA \& COOPER (1975a) usaram quatro populações segregantes de soja para avaliar a seleça precoce, o método genealógico e o SSD. Eles concluiram que - SSR foi o método mais eficiente por causa do menor esforço de seleção, permitir o rápido avanço de populações segregantes, e a não utilização de testos caros para rendimento até as geraçôes avançadas onde estes teste são mais eficientes. Com base nos resultados, os autores sugeriram que o método SSD fosse usado em situações onde o objetivo principal é a selecão de linhagens com alta produtividade de grãos.

BOERMA \& COOPER (1975b) usaram O SSD e o método genealógico para testar a efetividade da selecão pracoce para produção de grãos em linhas heterozigotas de 
soja. Em um dos quatro cruzamentos estudados, as linhas puras selecionadas por SSD foram significativamente superiores em rendimento e mais precoces que as linhas heterogêneas. Nos outros cruzamentos, não houve diferenças estatisticas para rendimento, embora as linhas puras foram usualmente mais precoces que as linhas heterogêneas.

BONETTI (1978) analisando o caráter teor de óleo nas sementes, estudou a seleção de sementes individuais em gerações iniciais através do Espectômetro de Ressonância Nuclear Magnética (NMR), método não destrutivo, e a sua possivel incorporarão ao método de melhoramento do SSD, reduzindo o número populacional pela eliminação de genótipos inferiores. As correlações existentes entre as sementes individuais e suas progênies para porcentagem de óleo, foram nulas ou baixas, indicando que a seleção precoce para teor de óleo nas sementes, baseada em sementes individuais, não é eficiente. 


\title{
3. MATERIAI E MÉTODOS
}

\subsection{Material genetico}

\begin{abstract}
Em janeiro de 1987, reailzaram-se cruzamentos dialélions com oito parentais, os guais foram escolhidos, com base na avaliação realizada em cerca de 400 genótipos, a nivel de campo e de laboratório (teor de proteína), correspondentes à coleção de soja mantida pelo setor de Genética Aplicada às Espécies Autógamas do Departamento de Genética da Escola Superior de Agricultura "Luiz de Queiroz", da Universidade de São Paulo.
\end{abstract}

Os cinco genótipos selecionados, quanto ao teor de proteina e produção de grãos semelhantes dos cultivares recomendados para plantio, foram: Gaúcha, La4910-215, OC-79230, BR-80-8858 e BR-80-14852. Os outros três genótipos parentais (PI-123439, EI-165896 e PI239235) correspondem às introduções de plantas (PI) dos Estados Unidos da América e foram cedidos pela EMBRAPA. Estas introduções apresentam elevados teores de proteina, entretanto, são pouco adaptadas às condições ambientais brasileiras e, portanto, pouco produtivas. Na Tabela 1, 
apresenta-se de forma sumarizada, algumas características dos parentais, envolvidos nos cruzamentos utilizados neste trabalho.

Com base nos resultados obtidos para teor de proteína e produção de grãos, da avaliação experimental da geração $E_{2}$, dos 28 cruzamentos, realizada no ano agrícoía 1987/88, selecionaram-se os quatro cruzamentos mais promissores para estes caracteres. Estes cruzamentos compreendem o material utilizado neste trabalho. os cruzamentos selecionados foram os seguintes:

1: $\mathrm{OC}-79230 \quad \mathrm{X} \quad \mathrm{BR}-80-8858$

2: $B R-80-8858 \quad X \quad B R-80-14853$

3: $B R-80-14853$ X PI-165896

4: BR-80-14853 X PI-239235

A descrição dos genótipos utilizados nos cruzamentos selecionados (PIMENTEL, 1991), encontra-se a seguir:

A - OC-79230: Linhagem brasileira, proveniente da OCEPAR, com ciclo aproximado de 60 dias (florescimento), hábito de crescimento determinado, flor branca, semente amarela, pubescência cinza e hilo marrom. 
B - BR-80-8858: Linhagem brasileira, proveniente da EMBRAPA-CNDSO, com ciclo aproximado de 53 dias para florescimento, hábito de crescimento indeterminado, flor roxa, semente amarela, pubescência e hilo dinza.

C. - BR-80-14853: Linhagem brasileira proveniente da EMBRABA-CNPSO, com ciclo aproximado para florescimento de 51 dias, hábito de crescimento indeterminado, flor roxa, semente verde, pubescência marrom e hilo preto.

D PI-165896: Linhagem norte-americana fornecida pelo Centro Nacional de Pesquisa de Soja (EMBRAPA), com ciclo aproximado de 47 dias para florescimento, hábito de crescimento determinado, flor roxa, semente preta, pubescência marrom e hilo preto.

E - PI-239235: Linhagem norte-americana fornecida pela EMBRAPA-CNPSO, com ciclo de 55 dias para florescimento, hábito de crescimento indeterminado, flor branca, semente amarela, pubescência e hilo sinza,

\subsection{Caracterização do ambiente}

o estudo foi realizado, em solo do tipo terra roxa estruturada série "Luiz de Queiroz" (RANzanI et al., 1966), na área experimental do Departamento de Genética da 
Escola Superior de Agricultura "Luiz de Queiroz", no município de Piracicaba, SP, situada a $22^{\circ} 42^{\prime} 30^{\prime \prime}$ de latitude sul, $47^{\circ} 38^{\prime} 00^{\prime}$ de latitude oeste e a $537 \mathrm{~m}$ de altitude em relação ao nivel do mar.

De acordo som a classificacão olimática de THORNTHWAITE para esta regiäo, a fórmula climática resulta em C2rA'a', ou seja, clima úmido com pequeno deficit de água, megatérmico, e com vegetaçäo o ano todo.

\subsection{Execução experimental}

\subsubsection{Método de melhoramento}

o método de melhoramento escolinido para a condução das sementes oriundas dos cruzamentos ̀̀ homozigose, foi o SSD isingle Seed Eescenti, onde foi colhida uma semente de cada planta da gerarão $F_{2}$ à geracão E7, para constituir a geraçäo seguinte.

Para o avanço dos materiais foi utilizada uma geração por ano, colhendo-se, sempre, uma semente por planta. No ano agrícola de 1992/33, foram colhidas plantas individuais, na geração $\mathrm{F}_{8}$, isto é, plantas $\mathrm{F}_{7}$ :8, para realizar os experimentos com as linhagens homozigóticas oriundas dos cruzamentos selecionados, que constituiu o material básico deste estudo. 


\subsubsection{Delineamento e caracteristicas do experimento}

Dentro de cada um dos quatro cruzamentos selecionados havia número de plantas diferentes, que deram origem a um numero diferente de linhagens por cruzamento. Eoi realizada uma seleção das plantas para número de sementes, visando obter numero suficiente de plantas para a realização deste trabalho.

Utilizou-se um delineamento em blocos ao acaso, onde o número de repetições foi igual a três. A parcela foi constituída de uma fileira de $1 \mathrm{~m}$ de comprimento com um espaçamento de $0,50 \mathrm{~m}$ e 13 plantas dentro da fileira no estande ideal.

o experimento foi instalado no campo experimental em 22 de novembro de 1993. Como o número de Iinhagens dentro de cruzamento era grande, as iinhagens do mesmo cruzamento foram divididas em conjuntos, cada um deles constituido por 20 Iinhagens, os dois parentais e cinco testemunhas, que foram a IAC-12, IAC-Eoscarin-31 e Bossier para produçäo de gràos, Biloxi e BरR-80-14887 para teor de proteína. Os cruzamentos OC-79230 X BR-80-8858 e BR-80-14853 X EI-165896 Eoram constituidos por quatro conjuntos nas duas primeiras repetições e três conjuntos na terceira repetiçäo. Os cruzamentos BR-80-8̈858 X BR-8014853 e BR-80-14853 X I-239235 foram constituidos por 
cinco conjuntos em duas repetições e por quatro conjuntos em três repetições.

- preparo do solo constou de uma aração profunda e duas gradagens. A abertura dos sulcos de plantio e a adubação utilizando-se $300 \mathrm{~kg} / \mathrm{ha}$ da fórmula $4-$ 20-20, foram realizadas simultaneamente, com um implemento adaptado para tal finalidade.

No momento da semeadura, que foi realizada manualmente, foi feito a inoculação das sementes com uma estirpe de Bradyrhizobium japonicum, pulverizando-se o sulco de plantio com uma solução do inoculante, seguida da semeadura e da cobertura dos sulcos.

Durante os primeiros dias após a semeadura houve a necessidade da realização da prática da irrigação, através de aspersores suspensos, no sentido de evitar falhas na germinação. Sempre que necessário, foi realizada a irrigação do campo experimental.

Foram realizadas pulverizações, quando necessárias, para o controle de insetos mastigadores e sugadores, principalmente o percevejo verde hezara viridula (L.), 1758) e a lagarta da soja (Anticarsia Gemmatasis Huber, 1818). 


\subsubsection{Caracteres avaliados}

As observações foram realizadas nas linhagens homozigoticas, oriundas de uma única planta. os caracteres avaliados foram os seguintes:

- DF: número de dias para o inicio do fiorescimento. Período que corresponde ao número de dias decorridos entre a semeadura e quando mais de $50 \%$ das piantas apresentavam flores. A determinação foi realizada por parcela em três repetições.

- AF: altura média das plantas da parcela en cni, no início do florescimento. Distância compreendida entre a base e o ápice da haste principal, nos primeiros dias do florescimento. Eoram medidas cinco plantas por parcela em três repetições. Para a realização das análises estatisticas foram utilizadas a média da altura das cinco plaritas.

- DM: número de dias para maturidade. Período que corresponde ao número de dias decorridos descie a semeadura até quando aproximadamente 95 옹 das vagens das plantas apresentarem-se maduras. A determinaçäo foi realizada por parcela em três repetições.

- AM: altura média das plantas da parcela em cm, na maturidade. Distância compreendida entre a base e o ápice da haste principal na época da maturidade. Foram 
medidas cinco plantas por parcela em três repetições. Para a realização das análises estatísticas foi utilizada a média das alturas das cinco plantas.

- AC: acamamento. Avaliado na maturidade através de uma escala de notas visuais que varia de 1 a 5 , onde a nota 1 corresponde a uma parcela com todas as plantas eretas e a nota 5 a uma parcela com todas as plantas acamadas. A avaliação foi realizada por parcela em três repetições.

- PG: produção de grãos. Avaliada na maturidade através do peso dos grãos $(g)$ de cada parcela em três repetições.

- TE: teor de proteina. $\bar{A}$ determinação do teor de proteína (옥 foi baseada na avaliagão do nitrogênio total pelo método de kjeidahl, a partir de farinha integral (grãos moidos sem extração do óleo) e com base no peso da matéria seca. Esta foi efetuada no laboratório de Genética Fisiológica do Departamento de Genética da ESALQ/USP. A determinação foi realizada em uma amostra de sementes de cada parcela em duas repetições

- To: teor de óleo. A determinação do teor de óleo (\&) foi efetuada no laboratório de Genética Fisiológica do Departamento de Genética da ESALQ/USE, utilizando-se o 
método do NMR (Espectômetro de Ressonância Nuclear Magnética); Convênio EINEP/ EMBRáPA-UAPDIA/GenéticaESALQ-USP. A determinação foi realizada em uma amostra de sementes de cada parcela em duas repetiçóes.

\subsubsection{Análises de variância}

As análises de variância foram realizadas para cada conjunto separadamente, bem cono através do agrupamento das análises de variância dos conjuntos de um mesmo cruzamento. As arálises foram efetuadas com o total de parcelas para o caráter produção de grãos e com médias de parcelas para os demais caracteres, sendo que para o acamamento os dados foram transformados para $\sqrt{X+1}$. As análises de covariância foram realizadas da mesma forma, considerando apenas, algumas combinações entre os oito caracteres. Inicialmente, foi realizada uma análise de variância em blocos ao acaso para cada conjunto de cada eruzamento. Posteriormente, os diferentes conjuntos de cada cruzamento foram agrupados em uma única análise.

As anáiises de variância individuais foram

realizadas de acordo com 0 delineamento experimental empregado e com o seguinte modeio:

$$
Y_{i j}=m+t_{i}+r_{j}+e_{i j}
$$


Onde:

$Y_{i j}$ è a observação referente ao tratamento "i" na repetição
"j";

m è a média geral;

$t_{i}$ é o efeito aleatório de tratamentos ilinhagensi; $i=1,2,3, \ldots \mathrm{T}$;

$r_{j}$ é o efeito aleatório de repeticões; $j=1,2,3, \ldots$ R;

$\boldsymbol{e}_{\boldsymbol{i j}}$ é o erro experimental associado à parcela ij.

Segundo este modelo, o esquema da análise da variância é o seguinte:

EV GL $\quad$ QM $\quad$ F $\quad$ E (QM)

\begin{tabular}{lcccc}
\hline REPETIÇÕES & $(\mathrm{R}-1)$ & $Q_{3}$ & $Q_{3} / Q_{1}$ & $\sigma^{2} \mathrm{E}+\mathrm{T} \sigma^{2} \mathrm{r}$ \\
TRATAMENTOS & $(\mathrm{T}-1)$ & $Q_{2}$ & $Q_{2} / Q_{1}$ & $\sigma^{2} \mathrm{E}+\mathrm{R} \sigma^{2} \mathrm{t}$ \\
RESIDUO & $(\mathrm{R}-1)(\mathrm{T}-1)$ & $\mathrm{Q}_{1}$ & & \\
\hline
\end{tabular}

Os graus de Iiberdade residuais frequientemente să pouco menores do que o esperade com base no produto (k-1) (T-1), devido à ocorrência de parceìas perdidas. us processos estatísticos para a estimação de parcelas perdidas impiicam na redução correspondente dos graus de I iherdade de residuo. 
A análise combinada dos diferentes conjuntos de cada cruzamento seguem um esquema hierárquico, baseado no sequinte modelo matemático:

$$
Y_{i j k}=m+t_{i(k)}+r_{j(k)}+c_{k}+e_{i j(k)}
$$

Onde:

$Y_{i j k}$ é a media do tratamento "i" da repetição "j" no conjunto "k";

$c_{k}$ é o efeito de conjuntos; $k=1,2,3, \ldots, c$;

Os demais parâmetros têm o mesmo significado do esquema anterior, sendo todos hierárquicos em relação ao efeito de conjuntos $c_{k}$.

Segundo este modelo, a análise de variância combinada toma a seguinte forma:

EV

GL

$\mathrm{QM}$

E

$E(Q M)$

CONJUNTOS $(C-1)$

REELTIÇÕES, CONUUNTOS

$C(R-1)$

$Q_{3}$

$83 / 2$

$\sigma^{2} E+T \sigma^{2} r$

TRATAMENTOS/CONJUNTOS

$C(T-1)$

8.2

Q.2/Q.1

$\sigma^{2} E+\bar{R} \sigma^{2}+$

RESIDUO MEDIO

$C(R-1)(T-1) \quad Q_{1}$ 
E importante ressaltar que o número de linhagens (tratamentos) variou entre os cruzamentos, variando portanto, o número de conjuntos por cruzamento, conforme descrito a seguir:

\begin{tabular}{|c|c|c|}
\hline Cruzamentos & $\begin{array}{l}\text { Número de } \\
\text { conjuntos }\end{array}$ & $\begin{array}{l}\text { Número de } \\
\text { Iinhagens }\end{array}$ \\
\hline $1-O C-79230$ X BR-80-8858 & 4 & 80 \\
\hline $2-B R-80-8858 \times$ X $B R-80-14853$ & 5 & 100 \\
\hline $3-\mathrm{BR}-80-14853 \mathrm{X}$ PI-165896 & 4 & 78 \\
\hline $4-B R-80-14853$ X PI-239235 & 5 & 97 \\
\hline
\end{tabular}

Para a obtenção do número de repetições médio para uso na análise de variância combinada, utilizou-se a média harmônica do número de repetições, onde:

$\vec{R}=2,67$ para os cruzamentos com quatro conjuntos;

$\bar{R}=2,73$ para os cruzamentos com cinco conjuntos.

Para os caracteres produção de grãos (PG), número de dias para o florescimento (DF), número de dias para a maturação (DM), altura da planta no florescimento (AF), altura da planta na maturação (AM) e acamamento 
(AC), foram avaliadas todas as linhagens possíveis nos quatro cruzamentos e em três repetições. Entretanto, para os caracteres teor de proteina (TP) e teor de óleo (TO) foram avaliadas apenas 60 linhagens (três conjuntos) por cruzamento e em apenas duas repetições. Todos estes fatores fazem com que o número de graus de liberdade varie entre cruzamentos e entre caracteres.

\subsubsection{Estimativas dos componentes de variância e dos parâmetros derivados}

Com base nas análises de variância combinadas foram estimados os seguintes parâmetros:

- Variância genética entre linhagens

$$
\hat{\sigma}^{2}{ }_{L}=\frac{\left(Q M_{T}-Q M_{E}\right)}{\bar{R}}=\hat{\sigma}^{2} t
$$

- Variância do erro experimental entre parcelas

$$
\hat{\sigma}^{2} \mathrm{E}=\mathrm{QM}_{\mathrm{E}}
$$

- Herdabilidade entre médias de parcelas

$$
h_{\bar{X}}^{2}=\frac{\sigma_{A}^{2}}{\left(\sigma_{A}^{2}+\frac{\sigma_{E}^{2}}{\bar{R}}\right)}
$$


- Coeficiente de variação experimental

$C V_{E}=\frac{\sqrt{\sigma_{E}^{2}}}{X} 100$

- Coeficiente de variação genético

$C V_{G}=\frac{\sqrt{\sigma_{G}^{2}}}{\bar{X}} 100$

Onde,

QMT : quadrado médio entre tratamentos (linhagens);

$\mathrm{QM}_{\mathrm{E}}$ : quadrado médio do erro experimental (residuo);

$\bar{R}$ : numero médio de repetições;

$\sigma_{A}^{2}$ : variância genética aditiva entre linhagens;

$\sigma_{G}^{2}$ : variância genética entre linhagens $\left(\sigma_{G}^{2}=\sigma_{A}^{2}\right)$;

$\sigma_{\bar{\varepsilon}}^{2}$ : variância do erro experimental entre parcelas.

$\bar{X}$ : média do caráter.

3.3.6 Análise de covariância e cálculo dos coeficientes de correlação genética

Foram estimados coeficientes de correlaçäo genética aditiva para seis combinações dois a dois entre 
os oito caracteres estudados ( PG X TP, PG X TO, TP X TO, PG $X D M, P C X A M \in A M X A C$ ).

As correlações foram estimadas através das estimativas das variâncias e das covariâncias. A obtenção da anàlise de covariância, para dois caracteres, foi feita com base nas análises de variância conjuntas para cada caráter e na análise de variância da soma dos dois caracteres, seguindo-se, sempre, a mesma estrutura em cada cruzamento, de acordo com KEMPTHORNE (1973).

$P M_{L_{X Y}}=\frac{1}{2}\left(Q M_{L_{Z}}-Q M_{L_{X}}-Q M_{L_{Y}}\right) \quad$ e,

$P M_{E_{X Y}}=\frac{1}{2}\left(Q M_{E_{Z}}-Q M_{E_{X}}-Q M_{E_{Y}}\right)$

onde,

$X$ e $Y$ : caracteres em estudo;

$Z$ : refere-se à soma cios dois $(Z=X+Y)$;

$\mathrm{QM}_{\mathrm{L}_{z}}$ : quadrado médio entre linhagens para a soma dos caracteres $(\mathrm{X}+\mathrm{Y})$;

$\mathrm{QM}_{\mathrm{E}_{z}}$ : quadrado médio do erro experimental para a soma dos caracteres $(X+Y)$;

QM $\mathrm{Lx}_{\mathrm{X}}$ : quadrado médio entre linhagens para o caráter $\mathrm{X}$; 
QM $\mathrm{E}_{\mathrm{X}}$ : quadrado médio do erro experimental para $\circ$ caráter X;

QM Ly $_{Y}$ : quadrado médio entre linhagens para o caráter Y;

$\mathrm{QM}_{\mathrm{E}_{\mathrm{y}}}$ : quadrado médio do erro experimental para o caráter $Y$;

$\mathrm{PM}_{\mathrm{Lxy}_{\mathrm{X}}}$ : produto médio entre linhagens entre os caracteres $\dddot{X} \in Y$.

$\mathrm{PM}_{\mathrm{E}_{X Y}}$ : produto médio do erro experimental entre os caracteres $\mathrm{X}$ e $\mathrm{Y}$.

A covariância genética (COVG) e a covariância ambiental (COV$E)$ entre os caracteres $X$ e estimadas através das seguintes expressões, a partir das análises combinadas:

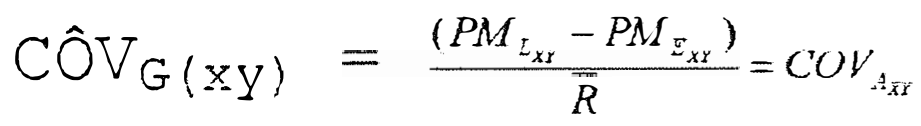

$\mathrm{Cov}_{\mathrm{E}(\mathrm{XY})}=\mathrm{PM} \mathrm{E}_{X Y}$

Einalmente, foi estimado o coeficiente de correlação genética aditiva e o coeficiente de correlação fenotipica entre médias de progênies através das seguintes expressões: 


$$
r_{A(x y)}=\frac{C^{\prime} U V}{\sqrt{\sigma_{A(x)}^{2} \cdot \sigma^{2}} A(y)}
$$

$$
r_{\bar{F}(x y)}=\frac{P M_{L(x y)}}{\sqrt{Q^{M} L(x) \cdot{ }^{M} L(y)}}
$$

Onde,

$$
\begin{aligned}
\boldsymbol{r}_{A(x y)}: \text { correiação genética aditiva entre os caracteres } \mathrm{X} \\
\text { e Y; }
\end{aligned}
$$

$\boldsymbol{r}_{\bar{F}(x y)}$ : correlação fenotípica entre médias de linhagens; $\sigma_{A(x)}^{2} \quad$ : variância genética aditiva do caráter $\mathrm{X}$;
$\sigma_{A(y)}^{2}$ : variância genética aditiva do caráter $\mathrm{Y}$.

\subsubsection{Progresso esperado com seleção entre linhagens}

O progresso genético (Gミ) com a seleção entre medias de inhagens foi obtido atraves da expressäo seguinte (EALCONER, 1989), considerando-se uma porcentagem de seleção de $10 \%$.

$$
G_{s}=i \frac{\sigma_{A}^{2}}{\sqrt{\sigma_{\bar{F}}^{2}}}
$$


Onde,

$\sigma_{A}^{2}$ : variância genética aditiva;

i : diferencial de seleção estandartizado ( $i=1,755)$;

$\sigma_{\bar{F}}^{2}$ : variancia fenotipica entre médias de linhagens.

Eoi, também, calculado o progresso com selerão em termos percentuais, da seguinte forma:

$\mathrm{GS} \%=\frac{G s}{x} 100$

Onde,

$\bar{x}$ : média das linhagens.

Eoi considerada a seleção truncada para um caráter, para a obtenção dos valores do progresso com seleção. Embora, na prática, isto não ocorra, pois é feita a seleção para vários caracteres simultaneamente, isto foi feito para determinar o potencial de seleção para cada raráter.

\subsubsection{Precisão das estimativas}

As estimativas de variancias genéticas e ambientais, coeficientes de herdabilidade e coeficientes de correlação foram testadas para verificar as precisões, 
segundo a metodologia apresentada por VELLO \& VENCOVSKY (1971) E VENCOVSKY \& BARRICA (1992).

- Erro associado à estimativa da variância genética aditiva entre linhagens

$D P_{L}=\sqrt{\operatorname{Var} r\left(\sigma_{A}^{2}\right)}$

$\operatorname{Vâr}\left(\sigma_{\dot{s}}^{2}\right)=\frac{2}{\mathrm{r}^{2}}\left[\left(\frac{\mathrm{QM}_{\mathrm{L}}^{2}}{\mathrm{gl}_{\mathrm{L}}+2}\right)+\left(\frac{\mathrm{QM}_{\mathrm{E}}^{2}}{\mathrm{gl}_{\mathrm{E}}+2}\right)\right]$

- Erro associado à estimativa da varianncia do erro experimental

$D P_{E}=\sqrt{\operatorname{Var}\left(\sigma_{E}^{2}\right)}$

$\operatorname{Vâr}\left(\sigma_{E}^{2}\right)=\frac{2 Q M_{E}^{2}}{g l_{E}+2}$

- Erro associado à estimativa do coeficiente de herdabilidade

$\mathrm{DP}_{\mathrm{h}}{ }^{2}=\sqrt{\operatorname{Va} r\left(h^{2}\right)}$

$\operatorname{Vâr}\left(h^{2}\right)=2\left(1-h^{2}\right)^{2}\left[\left(\frac{1}{g_{L}+2}\right)+\left(\frac{1}{g l_{E}+2}\right)\right]$

- Erro associado à estimativa do coeficiente de correlação genética aditiva 
$\mathrm{DP}_{\text {rA }}=\sqrt{\operatorname{Var}\left(r_{A}\right)}$

$\operatorname{Vâr}\left(r_{A}\right)=\frac{1}{g l_{L}} \frac{1}{r^{2} \iota_{1} l_{2}}\left\{\left[1+(\mathrm{r}-1) \mathrm{t}_{1}\right]\left[1+(\mathrm{r}-2) \mathfrak{\iota}_{2}+r f^{2}\right]\right\}+$

$$
+\frac{1}{\operatorname{gl}_{E} \mathbf{t}^{2} t_{1} t_{2}}\left[\left(1-t_{1}\right)\left(1-t_{2}\right)+r f^{2}\right]
$$

Onde,

$r$ : número médio de repetições;

$\mathrm{QM}_{\mathrm{L}}$ : quadrado médio entre linhagens;

$\mathrm{QM}_{E}$ : quadrado médio do erro experimental;

gIL : graus de liberdade entre linhagens;

glE : graus de liberdade do erro experimental;

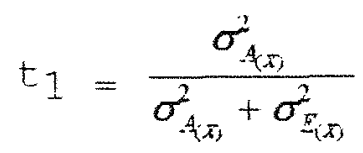

$t_{2}=\frac{\sigma_{A_{(n)}}^{2}}{\sigma_{A_{(n)}}^{2}+\sigma_{E_{(3)}}^{2}}$

$$
r f^{2}=\frac{C O V_{A_{x m}}+C O V_{E_{(X)}}}{\left.\sqrt{\left(\sigma_{A_{X}}^{2}+\sigma_{E_{X}}^{2}\right.}\right)\left(\sigma_{A_{Y}}^{2}+\sigma_{E_{Y}}^{2}\right)}
$$


$\sigma_{A_{\bar{X}}}^{2}$ : variância genética aditiva do caráter $\mathrm{X}$;

$\sigma_{A p}^{2} \quad$ : variância genética aditiva do caráter $Y$;

$\sigma_{E_{x}}^{2} \quad$ : variância do erro experimental do caráter $\ddot{x}$;

$\sigma_{E_{Y}}^{2}$ : variância do erro experimental do caráter Y.

- Erro associado à estimativa da correlação fenotípica entre médias de progênies

Por se tratar de uma correlação fenotípica, esta foi testada utilizando-se a Tabela A-13, de STEEI \& TORRIE \{1980\}, com n-2 graus de liberdade. 


\section{RESULTADOS E DISCUSSĂO}

Durante o período experimental, não ocorreu qualquer anomalia. Os desenvolvimentos vegetativo e reprodutivo foram normais. Foi obtida uma boa precisão experimental, conforme pode ser constatado abaixo.

Os coeficientes de variação experimental (CVe) representam a precisão experimental. Fortanto, quanto menor o valor do coeficiente de variação experimental, melhor à precisão do experimento. Na tabela 2, estão registrados os valores para os coeficientes de variação experimental (CVe), para os caracteres produção de grãos (PG), teor de proteina (TP), teor de óleo (TO), número de dias para maturação (DM), altura da planta na maturação (AM), numero de dias para o florescimento (DE), altura da planta no florescimento (ÄF) e acamamento (ÃC), para os quatro cruzamentos, obtidos das análises de variância combinadas.

Eoi possivel agrupar os caracteres avaliados em três grupos, quanto à precisão experimental, nos quatro cruzamentos. Os caracteres que apresentaram a melhor 
precisão experimental ou o menor coeficiente de variacão experimental foram o teor de proteina, tecr de óleo, número de dias para o florescimento e número de dias para a maturação, com CVe em torno de $2 \frac{8}{b}$ a 78 . Os caracteres que apresentaram os coeficientes de variação experimental intermediários, em torno de 98 a 138, foram: acamamento, altura da planta no florescimento e altura da planta na maturação. Estes valores coincidem com os encontrados por ZIMBACK (1992), exceto para teor de proteína que não foi avaliado e acamamento que apresentou o coeficiente de variação experimental igual a 20,478. O terceiro grupo, quanto à precisão experimental, é formado pelo carater produção de grãos, que apresenta $\circ \mathrm{CV}_{\varrho}$ em torno de 288 a 378.

\subsection{Análise de variância}

As análises de variâncias individuais para os caracteres $P G, T F, T O, D M, A M, D F, A F$ e AC dos cruzamentos OC-79230 X BR-80-8858, BR-80-8858 X BR-80-14853, BR-80$14853 \times$ PI-165896 e BR-80-14853 X PI-239235 estão apresentados nas Tabelas 3 a 10, respectivamente. A vâriạção no número de graus de liberdade deve-se à ocorrência de parcelas perdidas e ao número diferente de repetições das linhagens dos quatro cruzamentos. 
Na Tabela 11, são apresentados os valores referentes às médias populacionais $(\bar{x})$, para os caracteres: PG, TP, TO, DM, AM, DE, AF e AC dos quatro cruzamentos.

Para o caráter produção de grãos, as médias encontradas nos cruzamentos apresentaram um intervalo de variação de 178,3 a 255,9 g/parcela nos cruzamentos BR80-14853 X PI-165896 e BR-80-8858 X BR-80-14853, respectivamente. Os valores entre as médias do caráter teor de proteína mostraram-se bastante uniformes, praticamente não apresentando variação, ficando em torno de 39,78. Para o caráter teor de ólen, os valores relativos às médias apresentaram intervalo de variação de 21,18 para o cruzamento BR-80-14853 X PI-239235 a 22,38 para o cruzamento OC-79230 ※ BR-80-8858. Para o caráter numero de dias para a maturação as médias oscilaram entre 138 e 140 dias. O caráter altura da planta na maturação oscilou entre $72 \mathrm{~cm} /$ planta para o cruzamento oc-79230 X BR-80-8858 e 88 cm/planta para os cruzamentos BR-80-14853 X PI-165896 e BR-80-14853 X PI-239235. O numero de dias para o florescimento oscilou entre 59 e 62 dias, em media nos quatro cruzamentos. Para altura da planta na maturação as médias apresentaram uma variação de $57 \mathrm{~cm} /$ planta no cruzamento BR-80-14853 X PI-165896 a $67 \mathrm{~cm} /$ planta no cruzamento BR-80-14853 X PI-239235. E, para o caráter acamamento, as médias dos dados transformados para $\sqrt{X+1}$, apresentaram um intervalo de variação de 1,75 a 2,05 para 
os cruzamentos OC-79230 X BR-80-8858 e BR-80-14853 X PI165896, respectivamente. Como é possivel verificar, os caracteres produção de grãos e altura da planta na maturação foram os que apresentaram maiores amplitudes de variação entre médias entre os quatro cruzamentos.

As médias das testemunhas em cada um dos cruzamentos para os caracteres produção de grãos (PG), teor de proteina (TP), teor de óleo (TO), número de dias para maturação (DM), altura da planta na maturação (AM), número de dias para o florescimento (DF), altura da planta no florescimento $(A F)$ e acamamento ( $A C$ ) estão apresentadas na Tabela 12 para o cruzamento OC-79230 X BR-80-8858, na Tabela 13 para o cruzamento BR-80-8858 X BR-80-14853, na Tabela 14 para o cruzamento BR-80-14853 X PI-165896 e na Tabela 15 para o cruzamento BR-80-14853 X PI-239235. Como as análises do teor de proteína são demoradas, utilizou-se para este caráter apenas uma testemunha por cruzamento e somente no cruzamento BR-80-14853 X PI-239235 é que foram utilizadas duas testemunhas.

Eazendo-se uma comparação de médias entre as linhagens dos cruzamentos e as médias das testemunhas, observa-se que as médias para o caráter produção de grãos dos cruzamentos OC-79230 X BR-80-8858, BR-80-8858 X BR-8014853 e BR-80-14853 X PI-239235 foram superiores a todas as testemunhas. 
Para o caráter teor de proteína, os quatro cruzamentos foram, em média, superiores a todas as testemunhas, exceto a BR-80-14887. Esta só foi igualada sua média pelas linhagens do cruzamento BR-80-8858 X BR$80-14853$

O teor de óleo de todos os cruzamentos, em média, foi superior somente à testemunha BR-80-14887, sendo superados por todas as outras testemunhas.

O caráter número de dias para a maturação dos quatro cruzamentos foram, em média, mais tardios que todas as testemunhas exceto a BR-80-14887.

Para a altura da planta na maturação, o cruzamento OC-79230 X BR-80-8858 apresentou a menor média entre os cruzamentos, igualando-se às testemunhas Bossier e BR-80-14877. O cruzamento BR-80-8858 X BR-80-14853 igualou sua média com a da testemunha IAC-12. Os outros dois cruzamentos apresentaram menor porte que a IACEoscarin-31 e a Biloxi.

Todos os cruzamentos apresentaram o florescimento mais precoce que a IAC-12 e mais tardio que as demais testemunhas.

Para o caráter aitura da planta no florescimento, o cruzamento BR-80-14853 X PI-239235 apresentou-se, em média, plantas mais altas que todas as 
testemunhas, enquanto que o cruzamento BR-80-14853 X PI239235 apresentou-se, em média, de menor porte que todas as testemunhas, exceto a IAC-Foscarin-31, que foi igualada.

Para o caráter acamamento, todos os cruzamentos foram inferiores às testemunhas IAC-EOscarin31 e Biloxi. O cruzamento oc-79230 X BR-80-8858 apresentoul - maior nivel de acamamento entre os cruzamentos e as testemunhas.

As análises de variâncias combinadas para todos os conjuntos de um tratamento estũc apresentados nas Tabelas 16 a 19 para os cruzamentos: OC-79230 X BR-808858, BR-80-8858 X BR-80-14853, BR-80-14853 X RI-165895 e BR-80-14853 X PI-239235, juntamente com suas significâncias, respectivamente.

No cruzamento oC-79230 X BR-80-8858, todos os caracteres avaliados foram significativos, exceto o caráter acamamento. As linhagens do cruzamento BR-80-8858 X BR-80-14853 não apresentaram significância para os caracteres teor de proteina e altura da planta no florescimento. Nos cruzamentos BR-80-14853 X EI-165896 e BR-80-14853 X PI-239235, todos os caracteres apresentaram significância, exceto $\circ$ caráter teor de proteina. Portanto, os cruzamentos apresentam variação genótica para a grande maioria dos caracteres. 


\subsection{Análises genéticas}

\subsubsection{Produção de grãos}

As estimativas da variância genética em ııma população que se encontra na geraçäo $\bar{E}_{8}$, apresenta apenas um componente de variância genética, a variância genética aditiva. Eortanto, a partir de agora, os relatos serão feitos ap̣enas para a variância genética aditiva.

Na Tabela 20 são apresentados, para os quatro cruzamentos, as estimativas, relativas ao caráter produção de grãos, da variância genética aditiva, da variância do erro experimental entre parcelas, da herdabilidade ao nível de médias de linhagens, do coeficiente de variação genético e do ganho com seleção obtido entre linhagens. Todas as estimativas, com exceção do coeficiente de variação genético e do ganho com seleção, apresentam seus respectivos erros associados.

Äs estimativas da variância genetica aditiva entre linhagens, apresentaram uma relativa estabilidade nos quatro cruzamentos. O maior vaior $\{2721,249)$ foi encontrado no cruzamente BR-80-8858 X BR-80-14853, e o menor valor $(1544,596)$ foi obtido do cruzamento BR-8014853 X PI-165896. A diferença corresponde a 76,188. Estes valores da variância genética aditiva são inferiores aos encontrados por BRIM \& COCKERHAM $11961 !$, Os erros associados as estimativas apresentaram uma variação 
percentual de 24,38 a 33,28 , sendo que o erro associado à estimativa foi, percentualmente, maior, para o menor valor da estimativa da variância aditiva.

Às estimativas das variâncias do erro experimental entre parcelas apresentaram-se maiores que as estimativas da variância genética aditiva. Nos quatro cruzamentos, os erros associados às estimativas do erro experimental apresentaram valores entre 10,98 e 13,28, em relação às estimativas da variância do erro experimental entre parcelas.

Os coeficientes de herdabilidade apresentaram uma variação de 0,48 a 0,61, nos cruzamentos BR-80-14853 X PI-165896 e OC-79230 X BR-80-8858, respectivamente. Estes são superiores aos valores encontrados por JOHNSON et al. (1955a) e JOHNSON \& BERNARD (1963), e coincidindo com os valores encontrados por SHANNON et al. (1972). Os baixos valores dos erros associados indicam que as estimativas dos coeficientes de herdabilidade apresentaram boa precisão, exceto para o cruzamento BR-80-14853 X PI165896, onde o erro associado chegou a 23\%, embora pareça que o erro está alto devido à menor variância genética aditiva.

o coeficiente de variação genético oscilou de 20,388 a 22,778, indicando a liberação moderadamente 
constante da quantidade da variância genética aditiva, nos quatro cruzamentos.

- progresso esperado com seleção das 108 melhores linhagens foi em média de 27,758 , com pouca variação entre os cruzamentos, indicando boas possibilidades de seleção de linhagens mais produtivas, em média, nos quatro cruzamentos.

\subsubsection{Teor de proteína}

Na Tabela 21, estäo apresentados, para o carater teor de proteina, nos quatro cruzamentos, as estimativas da variância genetica aditiva, variância do erro experimental entre parcelas, do coeficiente de herdabilidade, em valor absoluto, do coeficiente de variação genético e do ganho com seleção obtido entre linhagens, e os respectivos erros associados.

A variância genética aditiva entre linhagens do cruzamento OC-79230 X BR-80-8858 apresentou um valor de 2,0311, ficando superior ao encontrado por BRIM \& COCKERHAM (1961). O erro associado a esta estimativa foi igual a 32,48 da estimativa da variância genetica aditiva. o cruzamento BR-80-8858 X BR-80-14853 apresentou o erro associado maior que a estimativa da varianuia genética aditiva, indicando que não foi detectada variação entre as 
linhagens neste cruzamento. O mesmo ocorre para os outros dois cruzamentos que apresentaram as estimativas da variância genética aditiva negativas. Isto ocorreu, provavelmente, devido a problemas na determinação do teor de proteína em laboratório, de modo que podem ser feitas inferências apenas sobre o primeiro cruzamento.

As estimativas da variância do erro experimental entre parcelas apresentaram uma oscilação de $3,4324(\mathrm{OC}-79230 \times \mathrm{BR}-80-8858)$ a 7,4163 (BR-80-14853 X PI165896). Os erros associados às estimativas do eirro experimental apresentaram uma oscilação em percentual de 18,68 a 20,98 , em relação às estimativas da variância do erro experimental.

A estimativa do coeficiente de herdabilidade ao nível de médias de linhagens no cruzamento OC-79230 X BR-80-8858 foi igual a 0,61, com o erro associado ficando em 16,98. Esta estimativa coincide com os valores encontracios por JOHNSON et al. (1955a) e JOHNSON \& BERNARD (1363). No cruzamento BR-80-8858 X BR-80-14853, a estimativa da herdabilidade foi iqual a 0,17, entretanto o erro associado apresentou-se superior $(0,2167)$ à estimativa, provavelmente, devido a não presença de variância genética aditiva, como já foi constatado.

o coeficiente de variação genético fai igual a 4,168 no cruzamento OC-79230 X BR-80-8858. 
- progresso esperado com seleção das $10 \%$ melhores linhagens foi em média de 4,938, para 0 cruzamento OC-79230 X BR-80-8858. Em virtude da ausência de variação no cruzamento BR-80-8858 X BR-80-14853, o valor encontrado para o progresso com seleção foi muito baixo, igual a 0,468 de proteína.

\section{2 .3 Teor de óleo}

Na Tabela 22 são apresentados, para os quatro cruzamentos, as estimativas, relativas ao caráter teor de óleo, da variância aditiva, da variância do erro experimental, da herdabilidade ao nivel de médias de linhagens, do coeficiente de variação genético e do ganho com seleção obtido entre linhagens, com seus respectivos erros associados.

As estimativas da variância genética aditiva entre linhagens, apresentaram variação de 0,1256 a 0,3365, coincidindo com as estimativas encontradas por BRIM \& COCKERHAM (1961). Os erros associados às estimativas apresentaram uma variação percentual de 32,88 a 60,5\%, sendo que $\circ$ erro associado à estimativa foi, percentualmente, maior, para o menor valor da estimativa da variância genética aditiva. 
As estimativas da variância do erro experimental entre parcelas apresentaram oscilação entre 0,3900 e 0,2087. Os erros associados às estimativas do erro experimental entre parcelas apresentaram oscilação de $18,6 \frac{8}{8}$ a 21,18, em relação às estimativas da variância do erro experimental.

? cruzamento BR-80-88.58 X BR-80-14853 apresentou a estimativa do coeficiente de herdabilidade igual a 0,46 , com o erro associado igual a 30,48 desta estimativa. Nos outros três cruzamentos, as estimativas dos coeficientes de herdabilidade apresentaram uma oscilação de 0,68 a 0,77, Eicando muito próximos aos valores encontrados por JOHNSON et al, (1955a), JOHNSON $\alpha$ BERNARD (1963), ZIMBACK (1992) e MIRANDÄ (1994). Os erros

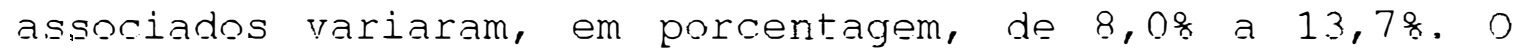
menor valor da estimativa da variância aditiva fez com que a estimativa do coeficiente de herdabilidade fosse bem menor e apresentando um erro bem maior em relação aos outros três cruzamentos.

o coeficiente de variação genético foi em média de $2,428$.

o progresso esperado com selecão foi em média, nos quatro cruzamentos, de 0,658 de óleo. O cruzamento oc79230 X BR-80-8858 foi o que apresenton o maior ganho percentual $(4,00 \%)$, indicando possibilidades de seleção de 
linhagens com maior teor de óleo. Já, o cruzamento BR-808858 X BR-80-14853 apresentou o menor ganho percentual (1,988), em virtude dos menores coeficientes de herdabilidade e de variação genético.

\subsubsection{Altura da planta na maturaçào}

$\mathrm{Na}$ Tabela 23 são apresentados, para os quatro cruzamentos, as estimativas, relativas ao carater altura da planta na maturação, da variância genética aditiva, da variânia do erro experimental eñtre parcelas, da herdabilidade ao nível de médias de linhagens, do coefieiente de variação genético e do gañho com seleção obtido entre linhagens, com seus respectivos erros associados.

As estimativas da variância genética aditiva entre linhagens, apresentaram uma oscilaçäo de 22,2846 a 772,7399. Os erros associados a estas estimativas variaram percentualmente de $15,6 \%$ a $25,6 \%$, sendo que 0 erro associado à estimativa foi, percentualmente maior, para o menor valor da estimativa da variancia aditiva.

As estimativas da variência do erro experimental entre parcelas apresentaram-se menores que as estimativas da variâneia genética aditiva, oscilando entre 42,1900 e 117,2700. Os erros associados às estimativas do 
erro experimental apresentaram variação de 10,98 a 12,48, em relação às estimativas da variância do erro experimental.

O cruzamento OC-79230 X BR-80-8858 apresentou a estimativa do coeficiente de herdabilidade igual a 0,59, com o erro associado igual a 14,38 do valor desta estimativa. Nos outros três cruzamentos, estas estimativas apresentaram uma variação de 0,82 a 0,95 , com os erros associados oscilando de 1,18 a 3,98. O menor valor da estimativa da variância genética aditiva, fez com que o coeficiente de herdabilidade fosse bem menor apresentando um erro associado bem maior, em relação os outros três cruzamentos.

O coeficiente de variação genético oscilou de 6,608 a 31,918, indicando a liberação diferenciada da quantidade de variância genética aditiva, nos cruzamentos.

- progresso esperado com seleção das $10 \%$ melhores linhagens apresentou variação de 8,48 a 51,48 , nos cruzamentos OC-79230 X BR-80-8858 e BR-80-14853 X PI165896, respectivamente, indicando possibilidades diferenciadas de seleção de linhagens para o caráter altura da planta na maturação, nos quatro cruzamentos. 


\section{2 .5 Número de dias para a maturação}

Na Tabela 24 são apresentados, para os quatro cruzamentos, as estimativas, relativas ao caráter número de dias para a maturação, da variância genética aditiva, da variânia do eiro experimental entre parcelas, da herdabilidade ao nivel de médias de linhagens, do coeficiente de vairiação genético e do ganho com seleção obtido entre Iinhagens com seus respectivos erros associados.

As estimativas da variância genética aditiva entre linhagens, apresentaram o maior valor $(17,6854)$ no cruzamento OC-79230 X BR-80-8858, e o menor valor $(2,4872)$ foi obtido do cruzamento BR-80-14853 X PI-239235. Os erros associados às estimativas apresentaram uma variação de 19, 18 a 34,18, sendo que o erro associado a estimativa foi, percentualmente maior, para o menor valor da estimativa da variância aditiva. Como a estimativa da variância aditiva é muito pequena, a expressão do erro ficou muito alta.

As estimativas da variancia do erro experimental entre parcelas apresentaram oscilação entre 7,7700 e 10,2000. Os erros associados às estimativas do erro experimental entre parcelas apresentaram variação de 0,8607 a 1,2381 e, em percentual de 10,98 a 12,48, em 
relação às estimativas da variância do erro experimental entre parcelas.

o cruzamento BR-80-14853 X PI-239235 apresentou a estimativa do coeficiente de herdabilidade igual a 0,47, com o erro associado igual a 21,10 desta estimativa. Nos outros três cruzamentos, estas estimativas apresentaram uma oscilação de 0,76 a 0,84 , com os erros associados variando de 3,98 a 5,68. Este intervalo de variação engloba o valor 0,79, encontrado por KToN \& TORRIE (1964). O menor valor da estimativa da variância aditiva do cruzamento BR-80-14853 X PI-239235, fez com que a estimativa do coeficiente de herdabilidade fosse bem menor e apresentando um erro bem maior em relação aos outros três cruzamentos.

O coeficiente de variação genético apresentou um intervalo de variação de 1,158 a 3,038.

o progresso esperado com seleção das $10 \%$ melhores linhagens foi em média de 3,698. O cruzamento or$79230 \times$ BR-80-8858 Él o que apresentou o maior ganho percentual $(4,86)$, indicando possibilidades de selerzão de linhagens mais precoces. Entretanto, o cruzamento BR-8014853 X PI-239235 apresentol o menor ganho com seleçã, igual a 1,318, praticamente um terço do ganho obtido com seleção para o cruzamento OC-79230 X BR-80-8858, em vircude do menor coeficiente de variação genético. 


\subsubsection{Acamamento}

Na Tabela 25 são apresentados, para os quatro cruzamentos, as estimativas, relativas ao caráter acamamento, da variância genética aditiva, da variância do erro experimental entre parcelas, da herdabilidade ao nível de médias de linhagens, do coeficiente de variação genético e do gantio com seleção obtido entre linhagens, com seus respectivos erros associados.

As estimativas da variància genética aditiva entrø linhagens, apresentaram uma variação de 0,0075 a 0,1049 . Os erros associados a estas estimativas oscilaram entre 17,2\% a 57,3\%, sendo que o erro associado ̀े estimativa foi, percentualmente maior, para o menor vaior da estimativa da variância aditiva.

As estimativas da variância do erro experimental entre parcelas oscilaram entre 0,0500 e 0,0600. Os erros associados às estimativas do erro experimental entre parcelas variaram entre $11,0 \%$ e 12,48.

O cruzamento OC-79230 X BR-80-8858 apresentou a estimativa do coeficiente de herdabilidade iqual a 0,29, com o erro associado igual a 50,4\% do valor desta estimativa. O cruzamento BR-80-14853 X PI-165896 apresentou a estimativa do coeficiente de herdabilidade igual a 0,85, com o erro associado iqual a 3,68 do valor da estimativa, enquanto que nos cruzamentos BR-80-14853 X 
PI-239235 e BR-80-14853 X PI-165896, as estimativas dos coeficientes de herdabilidade e seus erros associados, foram iquais a 0,50 e 0,58 , e 18,48 e 12,98, respectivamente. Estes dois últimos cruzamentos apresentaram os valores das estimativas dos coeficientes de herdabilidade semelhantes às encontradas por JOHNSON \& BERNARD (1963) e KWON \& TORRIE (1964), que foram 0,54 e 0,44 , respectivamente.

- coeficiente de variaŗão genético oscilou entre 4,95 e 15,80, indicando a liberação diferenciada da quantidade de variância genética aditiva.

O progresso esperado com selecão das 108 melhores lirhagens apresentou variação de 4,638 a 25,468 , nos cruzamentos OC-79230 X BR-80-8858 e BR-80-14853 X PI165896, respectivamente, indicando possibilidades diferenciadas de seleção de linhagens eretas, nos quatro cruzamentos.

\section{2 .7 Número de dias para o florescimento}

Na Tabela 26 são apresentados, para os quatro cruzamentos, as estimativas, relativas ao caráter número de dias para o florescimento das plantas, da variância genética aditiva, da variância do erro experimental entre parcelas, da herdabilidade ao nível de médias de 
linhagens, do coeficiente de variação genético e do ganho com seleção obtido entre linhagens, com seus respectivos erros associados.

Ảs estimativas da variância genética aditiva entre linhagens, apresentaram umintervalo de variação de 13,7079 a 29,714. Os erros associados às estimativas da variância genética aditiva apresentaram uma oscilação de 13,88 a 15,48 .

As estimativas da variância do erro experimental entre parcelas apresentaram-se menores que as estimativas da variância genética aditiva, oscilando entre 2,4200 e 3,8200. Os erros associados às estimativas do erro experimental entre parcelas apresentaram variação de 10,88 a 12,38 .

Ảs estimativas dos coeficientes de herdabilidade apresentaram uma relativa uniformidade, osciliando de 0,93 a 0,96, nos quatro cruzamentos, com os erros associados às estimativas variando de 0,78 a 1,48 .

O coeficiente de variação genético foi de 8,358 para o cruzamento OC-79230 X BR-80-8858 e, nos outros três cruzamentos, o coeficiente de variação genético apresentou-se relativamente uniforme, oscilando entre 6,198 e 6,948 . 
- progresso esperado com seleção das 108 melhores linhagens apresentou variação de 10,498 a 15,228, indicando boas possibilidades de seleção de linhagens para - caráter número de dias para o florescimento, nos quatro cruzamentos.

\subsubsection{Altura da planta no florescimento}

Na Tabela 27 são apresentados, para os quatro cruzamentos, as estimativas, relativas ao caráter altura da planta no florescimento, da variância genética aditiva, da variância do erro experimental entre parcelas, da herdabilidade ao nível de médias de linhagens, do coeficiente de variação genético e do ganho com seleção obtido entre linhagens, com seus respectivos erros associados.

As estimativas da variância genetica aditiva entre linhagens, apresentaram variação de 17,5805 a 115,6117. us erros associados às estimativas apresentaram uma variação percentual de 16,08 a 26,89 , sendo que o erro associado a estimativa foi, percentualmente maior, para o menor valor da estimativa da variância aditiva. Como a estimativa da variância aditiva foi muito pequena, a expressão do erro ficou muito alta. 
As estimativas da variância do erro experimental entre parcelas apresentaram oscilação entre 31,4900 e 57,5300. Os erros associados às estimativas do erro experimental apresentaram variação de 3,8471 a 6,3726 e, em percentual de 10,88 a 12,38 .

o cruzamento BR-80-14853 X PI-165896 apresentou a estimativa do coeficiente de herdabilidade igual a 0,57 , com o erro associado igual a 15,58 desta estimativa. Nos outros trôs cruzamentos, as estimativas dos coeficientes de herdabilidade apresentaram uma oscilação de 0,74 a 0,85 , com os erros associados variando de $3,4 \frac{8}{2}$ a, 38 . O menor valor da estimativa da variância genética aditiva do cruzamento BR-80-14853 X PI-165895, fez com que a estimativa do coeficiente de herdabilidade fosse bem menor e apresentando um erro bem maior em relação aos outros três cruzamentos.

o coeficiente de variação genético oscilou entre 7,38\% a 15,97\%, indicando a liberação diferenciada da quantidade de variância genética aditiva, nos quatro cruzamentos.

o progresso esperado com seleção foi em media de 17,44\%. O cruzamento BR-80-14853 X PI-239235 foi o que apresentou o maior ganho percentual $(25,698)$, indicando boas possibilidades de selecão de linhagens para este caráter. Entretanto o cruzamento BR-80-14853 X FI-165896 
apresentou o menor ganho com seleção, iqual a 9,738, praticamente um terço do ganho obtido com seleção para o cruzamento BR-80-14853 X PI-165896, em virtude dos menores coeficiente de herdabilidade e do coefiaiente de variação genético.

\subsection{Correlações entre caracteres}

As análises de covariância para as seis combinações escolhidas (produção de grãos $x$ teor de proteina, produção de grãos $x$ teor de óleo, teor de proteína $X$ teor de óleo, produção de grãos $X$ número de dias para a maturação, produção de grãos $X$ altura da planta na maturação e acamamento X altura da planta na maturação), para os quatro cruzamientos estão apresentados nas Tabelas 28 a 31. Nas Tabelas 32 a 35, estão apresentados as estimativas das covariancias genéticas e das covariâncias ambientais, para as seis combinações escolhidas, para os quatro cruzamentos.

Segundo JOHNSON et al. (1955b), as estimativas dos coeficientes de correlaçăo genetica e fenotipica entre caracteres são importantes no planejamento e na avaliação dos programas de meihoramento.

Desta maneira, nas Tabelas 36 a 39, estão apresentadas as estimativas dos coeficientes de correlação 
genética aditiva com seus respectivos erros associados e dos coeficientes de correlação fenotípica, das combinações de caracteres estudados, obtidos nos quatro cruzamentos.

A correlação genética entre produção de grãos e teor de proteína, apresentou um valor alto e positivo $(0,74)$ para o cruzamento OC-79230 X BR-80-8858, concordando com o valor encontrado por SIMPSON \& WILCOX (1983) e BYTH et al. (1969b), e discordando da maioria dos autores. Neste cruzamento foi encontrado o maior coeficiente de variação genética, podendo assim explicar a alta correlação genética. A correlação fenotípica foi significativa a $5 \frac{8}{8}$ de probabilidade, apresentando 0 valor igual a 0,29. No cruzamento BR-80-8858 X BR-80-14853, a estimativa de correlação genética foi inferior ao erro associado, indicando que esta estimativa não difere de zero, ou seja, para este cruzamento não foi detectada correlação genética entre produção de grãos e teor de proteina, o que também ocorreu com a correlação fenotípica. Não foi possível calcular as estimativas das correlações genéticas e fenotípicas para os outros dois cruzamentos, pois as estimativas da variância aditiva foram negativas. Os problemas ocorridos na determinação da estimativas de correlações genéticas e fenotípicas nos cruzamentos BR-80-8858 X BR-80-14853, BR-80-14853 X PI165896 e BR-80-14853 X PI-239235, aconteceram, provavelmente, devido problemas na determinação do teor de 
proteína em laboratório, fato este que tem ocorrido em outros experimentos.

As estimativas dos coeficientes de correlação genética para a combinação produção de grãos e teor de oleo, foram para os cruzamentos oC-79230 X BR-80-8858 e BR-80-8858 X BR-80-14853, muito próximas de zero com os erros associados maiores que as estimativas. Pode-se concluir, portanto, que não existe correiação entre estes dois caracteres nestes cruzamentos, coincidindo com os vaiores encontrados por kWON \& TORRIE (1964). Eara os cruzamentos BR-80-14853 X PI-165896 @ BR-80-14853 X PI239235 as estimativas dos coeficientes de correlação genéticas foram positivamente alta e medianamente alta $(0,78$ e 0,40), respectivamente. Os resultados encontrados por BYTH et al. (1969b), SHANNON et al. (1972) e SEBERN \& LAMEBERT (1984), concordam com os aqui apresentados, embora, em menor magnitude. Para esta combinaçã̊ de caracteres, a correlação fenotipica, ao contrário da genética, foi não significativa em todos os cruzamentos.

Para a combinação teor de proteína e teor de óleo, a estimativa dos coeficientes de correlação genética para o cruzamento OC-79230 X BR-80-8858 foi negativa ($0,41)$, coincidindo com os resultados encontrados por WEISS et al. (1952), JOHNSON et al. (1955b), JOHNSON \& BERNARD (1963), SHANNON et al. (1972), SIMPSON\& WILCOX (1983), 
SEBERN \& LAMBERT (1984) e MILLER \& EEHR (1979). Para O cruzamento BR-80-8858 X BR-80-14853, a estimativa do coeficiente de correlação genética foi praticamente iqual a zero, além do mais, o erro associado foi muito maior que a estimativa, indicando que a estimativa, realmente, não difere de zero. Portanto, para este cruzamento, não hà indicação de correlação entre os dois caracteres estudados. A correlação fenotípica não foi significativa para os dois cruzamentos citados anteriormente, embora a correlação genética do cruzamento oC-79230 X BR-80-8858 tenha dado significativa. Para os outros dois cruzamentos não foi possivel obter as estimativas dos coeficientes de correlação genética e correlação fenotípica entre teor de proteína e teor de óleo, pois as estimativas da variância aditiva foram negativas, pelas razões já descritas anteriormente.

A combinação dos caracteres produção de grãos e número de dias para maturação, apresentou a estimativa do coeficiente de correlação genética no cruzamento BR-8014853 X PI-239235 baixa e negativa, entretanto, como o erro associado foi alto e praticamente idêntico à estimativa, esta năo difere de zero; o mesmo ocorre para a estimativa da correlação fenotípica. Nos demais cruzamentos, as estimativas dos coeficientes de correlação genética apresentaram valeres altamente positivos, oscilando entre 0,57 a 0,72 . JOHNSON et al. (1955b), WEBER 
\& MOORTHY (1962) e ANAND\& TORRIE (1963) encontraram também, estimativas positivas de alta magnitude, o que é normalmente esperado para estes dois caracteres. Coincidindo com a correlação genética, a correlação fenotipica, também, foi altamente significativa para estes três cruzamentos, embora apresentando valores um pouco menores.

As estimativas de correlação genética entre produção de grãos e altura da planta na maturação foi para - cruzamento OC-79230 X BR-80-8858 altamente positivo e significativo $(0,65)$, coincidindo com a estimativa de correlação fenotipica $(0,469)$. O cruzamento BR-80̂-8858 X BR-80-14853, apresentou o valor da correlação genética medianamente positiva (0,28), não diferindo dos resultados encontrados por WEBER \& MOORTHY (1952) e ANAND \& TORRIE (1963). A correlação fenotipica, para este cruzamento, não foi significativa, diferindo da correlação genética. Para os cruzamentos BR-80-14853 X PI-165896 e BR-80-14853 X PI239235, os valores das estimativas das correlações genéticas não diferem de zero, já que o seus respectivos erros associados são menores que duas vezes os respectivos erros associados. O mesmo ocorre com as estimativas das correlaços fenotipicas que nãด foram significativas para estes dois cruzamentos. 
As estimativas das correlações genéticas entre acamamento e altura da planta na maturação, apresentaram valores altos e positivos num intervalo de variação de $0,58(O C-79230$ X $\quad$ BR-80-8858) a 0,96 (BR-80-14853 X PI165896), concordando com os estudos realizados por KaMIKOCA (1989). A.s estimativas das correlações fenotípicas coincidiram com as correlações genéticas, ou seja, todos os quatro cruzamentos apresentaram significância para as correlações fenotípicas. Inclusive, o cruzamento OC-79230 X BR-80-8858 que apresentou o menor nível de significância genética e fenotípica.

É importante observar, que foi encontrado estimativas de correlações genéticas diferentes para diferentes cruzamentos. Este fato, apresenta grande importancia dentro do melhoramento; as estimativas de correlaçöes genéticas näo säo absolutas e permanentes, devendo ser avaliadas separadamente em cada população em estudo.

\subsection{Análise final dos dados}

A análise comparativa da orden de variabilidade genética para produçäo de gräos encontrada nestes quatro cruzamentos, na geração F7:8, onde a variância genetica e $\left(\sigma_{\sigma}^{2}=2 \sigma_{A}^{2}\right)$, foi a mesma detectada na geração $\mathrm{F}_{2}$, onde a variância genética é 
$\left(\sigma_{\sigma}^{2}=\sigma_{s}^{2}+\sigma_{i}^{2}+\sigma_{E}^{2}\right)$ (PIMENTEI, 1991), ou seja, a ordem não foi alterada tornando as estimativas em ambas as gerações mais confiáveis, e indicando que a variância genética da geração $F_{2}$ foi um bom indicador da variância genética em gerações avançadas, mas também, que variância genética dominante não foi significativa, para este caráter, na geração $\mathrm{E}_{2}$.

No cruzamento $O C-79230$ X BR-80-8858, entre outros aspectos, aconteceu os seguintes fatores favoráveis:

1. A correlaçăo genetica entre produção de gräos e teor de proteína foi positiva, enquanto que a correlação genetica entre produçăo de grăos e teor de óleo foi negativa. Estes valores são o contrário da maioria dos cruzamentos, o que é muito bom para o melhoramento do teor de proteína.

2. Embora a correlação da produção de grãos com a altura da planta na maturacão seja positiva (o que é ruim), este último apresenta pouca variação, como atesta o CV g $^{\prime}$ indicando que a seleção em produção de grãos deve alterar pouco a altura da planta na maturação.

3. Também, apesar da correlação genética entre produção de grãos e número de dias para a maturação ser positiva, este ultimo é um caráter que apresenta pouca variação na maioria dos cruzamentos, indicando que a seleçăo 
para produção de grãos deve alterar muito pouco o número de dias para maturação.

4. Em resume, este cruzamento indica ser possível selecionar plantas com maior produção de grãos, maior teor de proteína e com padrões aceitáveis para os demais caracteres agronômicos.

$$
\text { - cruzamento BR-80-14853 X PI-239235, }
$$

apresentou as seguintes caracteristicas:

1. A correlação genética entre produção de grãos e teor de óleo foi positiva, o que é muito bom para o melhoramento do teor de óleo.

2. A correlação genética entre produção de grãos e número de dias para a maturação não foi significativa, ou seja, próxima de zero. Portanto, a seleção para produção de grãos não altera este caráter.

3. A correlação genética entre produção de grãos e altura da planta na maturação foi negativa, este ultimo é um caráter que apresenta cerca de 15 \& de variação $\left(\mathrm{CV}_{\mathrm{g}}\right)$, indicando que a seleção de linhagens para produção de grãos deve reduzir um pouco a altura da planta na maturação.

4. Em resumo, a seleção para produção de grãos, neste cruzamento, implica na seleção para alto teor de oleo, 
redução da altura da planta na maturação e não alteração no diclo.

$$
\text { o cruzamento BR-80-14853 X PI-165896, }
$$

apresentou as seguintes caracteristicas:

1. A correlação genética entre produção de grãos e teor de proteina foi alta e positiva, indicando possibilidades de seleção conjunta para estes dois caracteres.

2. Embora, a correlação entre produção de grãos e numero de dias para maturação foi, tambèm, alta e positiva, o que é ruim para o melhoramento, este ultimo caráter apresenta pouca variação, como atesta $\circ \mathrm{CV}_{g}$, indicando que a seleção para produção de grãos deve alterar muito pouco o ciclo.

3. A correlação genética entre produção de grãos e altura da planta na maturação não foi significativa, ou seja, não difere de zero, indicando que a seleção para prcdução de grãos não deve alterar a altura da planta na maturação.

4. Em resume, este cruzamento indica ser possivel seiecionar linhagens com maior produção de grãos, maior teor de óleo, sem alterar muito o cirlo e a altura da planta na maturação. 
Entre outros aspectos, o cruzamento BR-80-8858 X BR-80-14853, apresenta os seguintes fatores favoráveis:

1. As correlações genéticas entre produção de grãos e tenr de proteina e, entre produção de grãos e teor de óleo foram nulas.

2. A correlação genética entre produção de grãos e número de dias para maturação foi positiva. Entretanto, a pouca variação para o número de dias para a maturação, com base no CVg, indica que a seleção para produção de grãos não deve alterar muito o ciclo.

3. A correlação genética entre produção de grãos e altura da planta na maturação foi positiva. Indicando que a seleção para produção de grãos deve aumentar a altura da planta na maturação.

4. Apesar deste cruzamento não apresentar correlações genéticas significativas entre produção de grãos e tecr de proteína e nem, entre proủução de grãos e teor de óleo, a sua média de produção de grãos foi superior aos demais cruzamentos e às testemunhas, bem como, sua média de teor de proteína, também foi superior aos demais cruzamentos e igualando-se à melhor testemunha para este caráter. 


\section{CONCLUSÖES}

Os resultados obtidos no presente trabalho permitiram apontar as seguintes conclusões:

a) Os cruzamentos exibiram ampla variabilidade genética para a maioria dos caracteres, indicando que os parentais utilizados eram bem contrastantes.

b) Os caracteres produção de grãos e teor de óleo apresentaram coeficientes de herdabilidade relativamente altos, isto é, da ordem de 508 e $70 \%$ para produção de grãos e teor de sleo, respectivamente, que associados a coeficientes de variação genético altos indicam boas perspectivas de melhoramento para os mesmos.

a) Duanto ao teor de proteina, um dos cruzamentos apresentou também, coericiente de herdabilidade relativamente alto (da ordem de 608), associado a um aito coeficiente de variação genetico, indicando boas perspectivas para o melhoramento. Encretanto, nos demais cruzamentos näo foi possivel obter tais informą̃ões. 
d) Os coeficientes de correlação genética aditiva não foram consistentes entre os quatro cruzamentos, considerando os três caracteres principais. Em um deles, a produção de grãos apresentou correlação positiva e alta com teor de proteína, em dois apresentou correlação positiva e alta com teor de óleo, e no último não apresentou correlação significativa com nenhum dos caracteres.

e) os resultados gerais indicam portanto, que embora a maioria dos cruzamentos sejam promissores quanto a perspectivas de melhoramento para os três caracteres principais, devem ser adotadas estratégias diferentes para cada um. Existem populações mais apropriadas an melhoramento para produção de grãos e teor de óleo simultaneamente e populações mais apropriadas ao melhoramento para produção de grãos e teor de proteína simultaneamente.

f) Embura a literatura indique que a produçãu de grãos e 0 teor de proteína são negativamente correlacionados, verificou-se que esta não é uma regra geral, e que 0 sentido e a magnitude da correlação dependem da população, havendo casos em que o melhoramento simultâneo para os dois caracteres é mais fácil.

g) Quanto aos demais caracteres, isto é, número de dias para florescimento, altura da planta no 
florescimento, altura da planta na maturação e acamamento, no geral foram obtidos, também, coeficientes de herdabilidade relativamente altos, associados a altos coeficientes de variação genética, indicando boas perspectivas para o melhoramento.

h) O caráter dias para maturação, embora altamente correlacionado com produção de grãos ma maioria dos cruzamentos, apresentou um baixo coeficiente de variação genético, indicando que a seleção de genótipos mais produtivos näo deverá acarretar aumentos indesejáveis no ciclo. 


\section{REFERENCIAS BIBLIOGRÁFICAS}

ANAND, S.C. \& TORRIE, J.H. Heritability of yield and other traits and interrelationships among traits in the $\mathrm{F}_{3}$ and $\mathrm{F}_{4}$ generations of three soybean crosses. Crop Science, Madison, 3: 508-11, 1963.

BOERMA, H.R. \& COOPER, R.I. Comparison of three selection procedures for yield in soybeans. Crop Science, Madison, 15: 225-8, 1975a.

BOERMA, H.R. \& COOPER, R.L. Effectiveness of earlygeneration yield selection of heterogeneous lines in soybeans. Crop Science, Madison, 15: 313-5, 1975b.

BONETTI, L.P. The use of single seed selection in combination with single seed descent for modifying oil content in soybean [Glycine max (L.) Merrillj. Urbana - Illinois, 1978. 63p. Mestrado - University of Ilinois at Urbana - Champaign).

BRIGGS, E.N. \& KNOWLES, P.F. Introduction to plant breeding. New York, Reinhold, 1967. 
BRIM, C.A. Quantitative genetics and breeding. In: CALDWELL, B.E., ed. Soybeans: impovement, production, and uses. Madison, American Society of Agronomy, 1963. p. $155-86$.

BRIM, C.A. Modified pedigree method of selection in soybeans. Crop Science, Madison, 6: 220, 1966.

BRIM, C.A.; JOHNSON, H.W.; COCKERHAM, C.C. Multiple selection criteria in soybeans. Agronomy Journal, Madison, 51: 42-6, 1959.

BRIM, C.A. \& COCKERHAM, C.C. Inheritance of quantitative characters in soybeans. Crop science, Madison, 1: 187-90, 1961.

BRIM, C.A.; SCHUTZ, W.M.; COLLINS, F.I. Nuclear magnetic resonance analysys for oil in soybeans with implications in selection. Crop Science, Madison, 7: $220-2,1967$.

BRIM, C. A. S STUBER, C. W. Application of genetic male sterility to recurrent selection schemes in soybeans. Crop Science, Madison, 13: 528-30, 1973.

BRIM, C.A. \& BURTON, J.W. Recurrent selection in soybean. II. Selection for increased percent protein in seeds. Crop Science, Madison, 19: 494-8, 1979. 
BURTON, J.W. Breeding soybeans for improved protein quantity and quality. In: WORLD SOYBEAN RESEARCH CONFERENCE, 3., Ames, 1984. Proceedings, edited by R. SHIBLES. Boulder, Westview, 1984. p. 361-7.

BURTON, J.W. Breeding soybeans cultivars for increased seed protein percentage. In: WORLD SOYBEAN RESEARCH CONEERENCE, 4., Buenos Aires, 1989. Proceedings, edited by A.J. PASCALE. Buenos Aires, Orientacion Gráfica, 1989. p. $1079-85$.

BURTON, J.W. \& BRIM, C.A. Recurrent selection in soybeans. III. Selection for increased percent oil in seeds. Crop Science, Madison, 21: 31-4, 1981.

BYIH, D.E.; WEBER, C.A.; CALDWEL, B.E. Correlated truncation selection for yield in soybeans. Crop Science, Madison, 9: 699-702, 19696.

CAPUNO, O.B. I. Method for breeding high-protein cultivars of soybeans. II. Transfer of Phythophthora resistance in soybean [Giycine max (L.) Merrill] by backcrossing. Dissertation Abstracts International, B (Sciences and Engineering) 47: 1334B-5B, 1966.

COLIINS, F.I. S CARTTER, J.L. Variability in chemical composition of seed from aifferent portions of the soybean plant. Agronorm Journal, Madison, 48: 216-9, 1956. 
CROISSANT, G.L. \& TORRIE, J.H. Evidence of nonadditive effects and linkage in two hybrid populations of soybeans. Crop Science, Madison, 11: 675-7, 1971.

DUDLEY, J.W. \& MOLL, R.H. Interpretation and use of estimates of heritability and genetic variances in plant breeding. Crop Science, Madison, 9: 257-62, 1969.

EMPIG, L.T. \& FEHR, W.R. Evaluation of methods for generation advance in bulk hybrid soybean populations. Crop Science, Madison, 11: 51-4, 1971.

EALCONER, D.S. Introduction to quantitative genetics. 3. ed. London, Longman, 1989, 438p.

FEHR, W.R. Soybean. In: __, ed. Principles of cultivar development - crop science. New York, Macmilian, 1987. cap. 14, p. 533 - 76.

FEHR, W.R. \& WEBER, C.R. Mass selection by seed size and specific gravity in soybean populations. Crop Science, Madison, 8: 551-4, 1968.

HANSON, W.D. Heritability. In: HANSON, W.D. \& ROBINSON, H.F., ed. Statistical genetics and plant breeding. Washington, National Academy of Sciences. 1963. p. 125-39. 
HANSON, W.D.; LEFFEL, R.C.; HOWELL, R.W. Genetic analysis of energy production in the soybean. Crop science, Madison, 1: 121-6, 1961.

HAR'TWIG, ヒ..t. Breeding soybeans for high protein content and quality. In: INTERNATIONAI ATOMIC ENERGY AGENCY. New approaches to breeding for improved plant protein. Vienna, IAEA, 1959. P. 67-70.

HARTWIG, E.E. \& COLLINS, F.I. Evaluation of density classification as a selection technique in breeding soybeans for protein or oil. Crop science, Madison, 2: $159-62,1962$.

HARTWIG, E.E. \& HINSON, K. Association of chemical composition of seed and seed yieid of soybeans. Crop Science, Madison, 12: 829-30, 1972.

HAZEL, L.N. The genetic basis for constructing selection indexes. Genetics, New York, 28: 476-90, 1943.

HOLBROOK, C.C.; BURTON, J.W.; CARTER JUNIOR, T.E. L'valuation of recurrent restricted index selection for increasing yield while holding seed protein constant in soybean. Crop Science, Madison, 29: 324-9, 1989.

ISHIGE, T. Biometrical analysis and estimation of the number of genes for seed protein content of soybean, 
Glycine max (L.) Merrill. Japan Agricultural Research Quartely, Tokio, 17: 230-5, 1984.

JENSEN, N.F. The single descent method. In:

Plant breeding methodology. New York, willey, 1988. cap. 21, p. 271-96.

JOHNSON, H.W. \& BERNARD, R.L. Soybean genetics and breeding. Advances in Agronomy, New York, 14: 149-221. 1962 .

JOHNSON, H.W. \& BERNARD, R.L. Soybean genetics and breeding. In: NORMAN, A.G., ed. The soybean genetics, breeding, physiology, nutrition, management. New York, Academic Press, 1963. p. 1-73.

JOHNSON, H.W.; ROBINSON, H.F.; COMSTOCK, R.E. Estimates of genetic and environmental variability in soybeans. Agronomy Journal, Madison, 47: 314-8, 1955a.

JOHNSON, H.W.; ROBINSON, H.P.; COMSTOCK, R.E. Genotypic and phenotypic correlations in soybeans and their implications in selection. Agronomy Journal, Madison, 47: $477-83,1955 b$.

KAMIKOGA, M.K. Herança do acamamento e associações com outros caracteres em soja [Glycine max (L.) Merrill]. Piracicaba, 1989. 130p. (Mestrado - Escola Superior de Ayricultura "Luiz de Queiroz"/USP). 
KELLY, J.D. \& BLISS. F.A. Heritability estimates of percentage seed protein and available methionine and correlations with yield in dry beans. Crop science, Madison, 15: 753-7, 1975.

KEMPTHORNE, O. An introduction to genetic statistics. 2. ed. Ames, Iowa State University Press. 1973. 545p.

KEMPTHORNE, O. \& NORDSKOG, A.W. Restricted selection indeces. Biometrics, Alexandria, 15: 10-9, 1959.

KENWOR'IHY, W.J. \& BRIM, C.A. Recurrent selection in soybeans. I. Seed yield. Crop Science, Madison, 19: $315-8,1979$.

KROBER, O.A. \& CARTTER, J.L. Quantitative interrelations of protein and nonprotein constituints of soybeans. Crop Science, Madison, 2: 171-2, 1962.

KWON, S.H. \& TORRIE, J.H. Heritability of and interrelationships among traits of two soybean populations. Crop Science, Madison, 4: 196-8, 1954.

LAM-SÁNCHEZ, A.; DURIGAN, J.F.; ASSIS, G.M. de. Respostas de genótipos de soja iglyoine max it.) Merrilll ao retardamento de colheita quanto aos conteúdos de proteina é São Paulo, 17: 121-5, 1989. 
MCKENDRY, A.L.; MCVETTY, P.B.E.; VOIDENG, H.D. Inheritance of seed protein and seed oil content in early maturing soybean. Canadian Journal of Genetics and Citology, Ottawa, 27: 603-7. 1985.

MILIER, J.E. \& FEHR, W.R. Direct and indirect recurrent selection for protein in soybeans. Crop Science, Madison, 19: 101-6, 1979.

MILLER, J.E. \& FEHR, W.R. Direct and indirect selection for protein in soybeans. Crop Science, Madison, 19: $101-6,1979$.

MIRANDA, M.A.C. de Seleção recorrente divergente para peso de sementes e porcentagem de óleo em soja com o uso de machoesterelidade genetica. Piracicaba, 1994. 112p. (Doutorado - Escola Superior de Agricultura "Luiz de Queiroz"/USP).

MOREIRA, R.M.P. Predição do comportamento de cruzamentos dialélicos de soja avaiados na geração $\mathrm{F}_{3}$ em cultivo de inverno. Piracicaba, 1992. 95p. (Mestrado - Escola Superior de Agricultura "Luiz de Queiroz"/USP) .

OPENSHAW, S.J. \& HADLEY, H.H. Selection indexes to modify protein concentration of soybean seeds. Crop science, Madison, 24: 1-4, 1984 . 
PIMENTEL, A.M. Cruzamentos dialélicos em soja com ênfase em teor de proteina e produção de grãos. Piracicaba, 1991. 150p. (Mestrado - Escola Superior de Agricultura "Luiz de Queiroz"/USP).

RANRANI, G.; FREIRE, O.; KINJO, T. Carta de solos do municipio de Piracicaba. Piracicaba, ESALQ/Centro de Estudos de Solos, 1966. 86p. (mimeografado).

SERERN, N.A. \& LAMBERT, J.W. Ef fect of stratification for pereent protein in two soybean populations. Crop Science, Madison, 24: 225-8, 1984.

SHANNUN, J.G.; WILCOX, J.R.; PROBST, A.H. Estimated gaıns from selection for protein and yield in the $F_{4}$ generation of six soybean populations. Crop Science, Madison, 12: 824-6, 1972.

SHORTER, R.; BLYTH, D.E.; MUNGOMERY, V.E. Estimates of selection parameters associated with protein and oil content of soybean seeds [Glycine max (L.) Merrili]. Australian Journal of Agriculture Research, Melbourne, 28: $211-22.1976$.

SIMLSUN, A.M. Jr. \& WLLCOX, J.K. Genetic and phenotypic association of agronomic characteristics in four high protein soybean population. Crop Science, Madison, 23: $1077-81,1983$ 
SMITH， R.R. \& WEBER, C.R. Mass selection by specific gravity for protein and oil in soybean populations. Crop Science, Madison, 8: 373-7, 1968.

STEEL, R.D.D. \& TORRIE, J.H. Principles and procedures of statistics. 2. ed. New York, McGraw-Hill, 1980. $633 \mathrm{p}$.

THORNE, J.C. \& EEHR, W.R. Incorporation of high-protein, exotic germplasm into soybean populations by 2- and 3way crosses. Crop Science, Madison, 10:652-5, 1970.

VELIO, N.A. \& VENCOVSKY, R. Variâncias associadas às estimativas de variâncias genéticas e coeficientes de herdabilidade. Relatório Científico do Departamento de Genética, Piracicaba, 8: 238-48, 1974.

VENCOVSKY, R. \& BARRIGA, P. Genética biométrica no fitomelhoramento. Ribeirão Preto, Revista Brasileira de Genética, 1992. 496p.

VERNETTI, F.J. Genética da soja - Caracteres quantitativos. In: _._. Soja: genetica e melhoramento. Campinas, Fundação Cargill, 1983. p. $727-40$.

WEBER, C.R. \& MOORTHY, B.R. Heritable and non heritable relationships and variability of oil contrast and 
agronomic characters in the $F_{2}$ generation of soybean crosses. Agronomy Journal, Madison, 44: 202-9, 1952. WEHRMANN, V.K.; FEHR,W.R.; CIANZIO, S.R.; CAVINS, J.F. 'Iransfer of high seed protein to high-yielding soybean cultivars. Crop Science, Madison, 27: 927-31, 1987.

WEISS, M.G.; WEBER, C.R.; WILLIAMS, L.F.; PROBST, A.H. Correlation of agronomic characters and temperature with seed compositional characters in soybeans, as influenced by variety and time of planting. Agronomy Journal, Madison, 44: 289-97, 1952.

LIMBACK, L. Cruzamentos em cadeia entre genotipos adaptados e exóticos de soja com ênfase na produção de Oleo. Piracicaba, 1992. 178p. (Doutorado - Escola Superior de Agricultura "Luiz de Queiroz"/USP) • 
T A B E I A S 
Tabela 1 - Características botânicas e agronômicas dos cinco genótipos de soja, utilizados como parentais, Piracicaba $1987 / 88$.

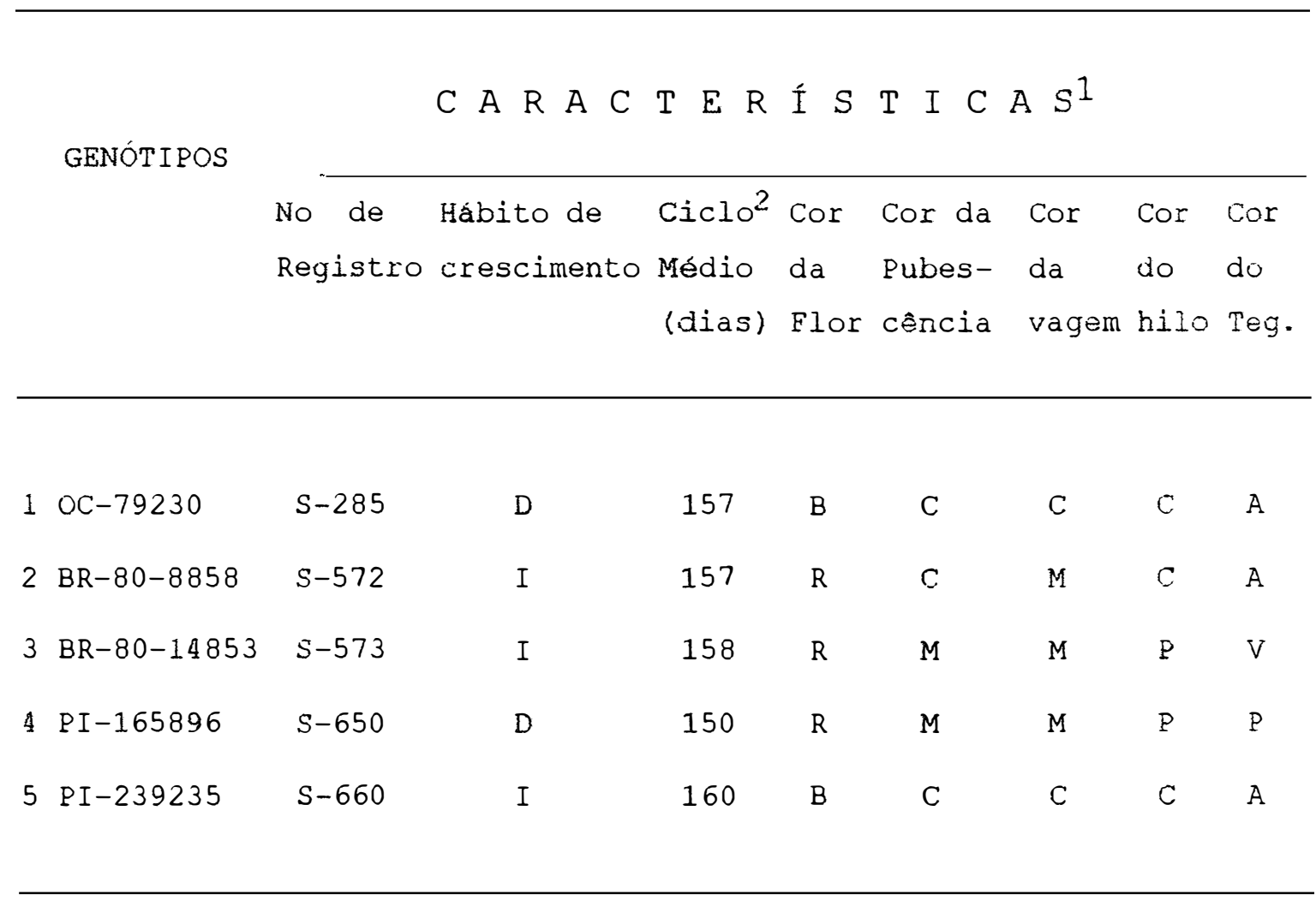

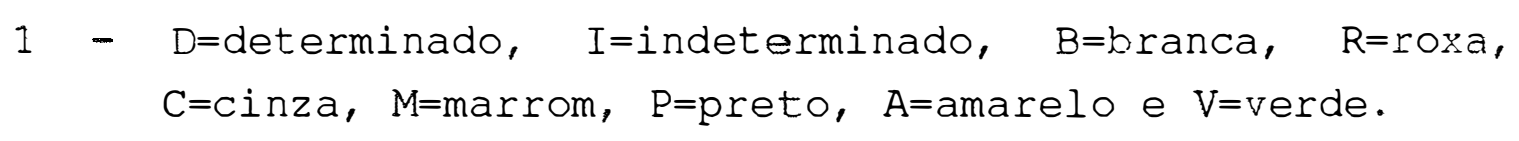

2 - Número de dias para a maturação.

Fonte: PIMENTEL (1991). 
Tabela 2 - Valores dos coeficientes de variação experimental $\left(\mathrm{CV}_{e}\right)$, expressos em porcentagem, para os caracteres produção de grãos (PG), teor de proteína (TP), teor de óleo (TO), número de dias para maturação (DM), altura de plantas na maturação(AM), número de dias para o florescimento $(D F)$, altura de plantas no florescimento $(A F)$ e acamamento $(A C)$, relativo às linhagens oriundas dos quatro cruzamentos: (1) OC-79230 X BR-80-8858, (2) BR-80-8858 X BR-80-14853, (3) BR-80-14853 X PI165896 e (4)BR-80-14853 X PI-239235.

Caráter

Cruzamentos

(1)

(2)

(3)

(4)

$\begin{array}{lrrrr}\text { PG (g/parcela) } & 28,545 & 33,407 & 37,601 & 35,518 \\ \text { TP (g) } & 4,681 & 5,756 & 6,898 & 6,665 \\ \text { TO (g) } & 2,329 & 2,927 & 2,125 & 2,265 \\ \text { DM (dias) } & 2,189 & 2,291 & 2,256 & 2,026 \\ \text { AM (cm) } & 9,077 & 11,662 & 12,292 & 11,025 \\ \text { DF (dias) } & 2,765 & 2,630 & 2,634 & 3,154 \\ \text { AF (cm) } & 9,010 & 10,155 & 10,515 & 11,262 \\ \text { AC (nota) } & 12,778 & 11,769 & 10,908 & 12,066\end{array}$

1: Valores transformados para $\sqrt{x+1}$. 
Tabela 3 - Resumo das análises de variâncias individuais para o cruzamento OC-79230 X BR-80-8858, para os caracteres: produção de grãos (PG), teor de óleo (TO), teor de proteína (TP) e acamamento (AC), para quatro conjuntos experimentais.

\begin{tabular}{|c|c|c|c|c|c|c|c|c|}
\hline \multirow[t]{2}{*}{ EV } & \multicolumn{2}{|r|}{$\mathrm{PG}$} & \multicolumn{2}{|c|}{ TO } & \multicolumn{2}{|c|}{$\mathrm{TP}$} & \multicolumn{2}{|c|}{$\mathrm{AC}$} \\
\hline & GL & QM & GL & $Q M$ & GL & $Q M$ & GL & QM \\
\hline Linhagens & 19 & 7650,21 & 19 & 1,681 & 19 & 7,216 & 19 & 0,430 \\
\hline Residuo & 36 & 1273,26 & 17 & 0,270 & 17 & 4,623 & 37 & 0,634 \\
\hline Linhagens & 19 & 8059,14 & 19 & 0,972 & 19 & 7,079 & 19 & 0,929 \\
\hline Residuo & 38 & 4856,26 & 19 & 0,246 & 19 & 2,385 & 38 & 0,621 \\
\hline Linhagens & 19 & 11344,04 & 19 & 0,847 & 19 & 12,272 & 19 & 0,964 \\
\hline Residuo & 38 & 2587,97 & 16 & 0,294 & 16 & 3,408 & 38 & 0,467 \\
\hline Linhagens & 19 & 10377,09 & & & & & 19 & 0,981 \\
\hline Residuo & 15 & 8852,91 & & & & & 18 & 0,851 \\
\hline
\end{tabular}

A sequência refere-se aos conjuntos 1, 2, 3 e 4, respectivamente 
Tabela 4 - Resumo das análises de variâncias individuais para o cruzamento OC-79230 X BR-80-8858, para os caracteres: número de dias para $\bigcirc$ florescimento $(D F)$, altura da planta no florescimento $(A F)$, número de dias para a maturação (DM) e altura da planta na maturaçäo (AM), para quatro conjuntos experimentais.

\begin{tabular}{|c|c|c|c|c|c|c|c|c|}
\hline \multirow[t]{2}{*}{ EV } & \multicolumn{2}{|c|}{$D F$} & \multicolumn{2}{|c|}{$A E$} & \multicolumn{2}{|c|}{$\mathrm{DM}$} & \multicolumn{2}{|c|}{ AM } \\
\hline & GL & $Q \mathrm{M}$ & GL & $Q M$ & GL & QM & GL & $Q M$ \\
\hline Linhagens & 19 & 103,523 & 19 & 168,171 & 19 & 96,071 & 19 & 103,213 \\
\hline Residuo & 38 & 2,436 & 38 & 35,157 & 37 & 16,700 & 37 & 49,645 \\
\hline Linhagens & 19 & 87,490 & 19 & 216,026 & 19 & 32,887 & 19 & 94,855 \\
\hline Resíduo & 38 & 2,643 & 38 & 36,101 & 38 & 6,945 & 38 & 49,28 \\
\hline Linhagens & 19 & 86,207 & 19 & 189,046 & 19 & 61,070 & 19 & 110,899 \\
\hline Residuo & 38 & 3,041 & 38 & 26,609 & 38 & 6,810 & 38 & 31,140 \\
\hline Linhagens & 19 & 51,735 & 19 & 129,752 & is & 35,677 & 19 & 97,810 \\
\hline Residuo & 18 & 4,126 & 18 & 24,300 & 18 & 3,693 & 18 & 35,247 \\
\hline
\end{tabular}

A sequência refere-se aos conjuntos 1, 2, 3, e 4, respectivamente 
Tabela 5 - Resumo das análises de variâncias individuais para o cruzamento BR-80-8858 X BR-80-14853, para os caracteres: produção de grãos (PG), teor de óleo (TO), teor de proteína (TP) e acamamento (AC), para cinco conjuntos experimentais.

\begin{tabular}{|c|c|c|c|c|c|c|c|c|}
\hline \multirow[t]{2}{*}{ EV } & \multicolumn{2}{|r|}{ PG } & \multicolumn{2}{|c|}{ TO } & \multicolumn{2}{|c|}{$\mathrm{TP}$} & \multicolumn{2}{|c|}{$\mathrm{AC}$} \\
\hline & GL & $Q M$ & GL & $\mathrm{QM}$ & GL & $\mathrm{QM}$ & GL & $\mathrm{QM}$ \\
\hline Linhagens & 19 & 21988.30 & 19 & 0.919 & 19 & 7.956 & 19 & 1.753 \\
\hline Residuo & 36 & 8151.79 & 18 & 0.470 & 18 & 4.934 & 37 & 0.512 \\
\hline Linhagens & 19 & 13139,42 & 19 & 0,849 & 19 & 4,676 & 19 & 2,597 \\
\hline Residuo & 35 & 10282,79 & 19 & 0,292 & 19 & 6,890 & 37 & 1,113 \\
\hline Linhagens & 19 & 8514,69 & 19 & 0,409 & 19 & 6,487 & 19 & 1,133 \\
\hline Resíduo & 37 & 6487,04 & 19 & 0,413 & 19 & 4,000 & 35 & 0,699 \\
\hline Linhagens & 19 & 14704,74 & & & & & 19 & 1,869 \\
\hline Resíduo & 38 & 6024,09 & & & & & 38 & 0,411 \\
\hline Linhagens & 19 & 15344,95 & & & & & 19 & 1,126 \\
\hline Residuo & 19 & 4408,14 & & & & & 19 & 0,768 \\
\hline
\end{tabular}

A sequència refere-se aos conjuntos $1,2,3,4$ e 5, respectivamente 
Tabela 6 - Resumo das análises de variâncias individuais para o cruzamento BR-80-8858 X BR-80-14853, para os caracteres: número de dias para $\circ$ florescimento $(\mathrm{DF})$, altura da planta no florescimento ( $\mathrm{AF})$, número de dias para a maturação (DM) e altura da planta na maturação (AM), para quatro conjuntos experimentais.

\begin{tabular}{|c|c|c|c|c|c|c|c|c|}
\hline \multirow[t]{2}{*}{ EV } & \multicolumn{2}{|c|}{$D E$} & \multicolumn{2}{|r|}{$\mathrm{AF}$} & \multicolumn{2}{|c|}{$D M$} & \multicolumn{2}{|c|}{$A M$} \\
\hline & GL & QM & GL & QM & GL & QM & GL & QM \\
\hline Linhagens & 19 & 61,280 & 19 & 167,985 & 19 & 63,736 & 19 & 221,567 \\
\hline Residuo & 38 & 2,227 & 38 & 59,710 & 37 & 5,950 & 37 & 129,851 \\
\hline Linhagens & 19 & 61,869 & 19 & 220,906 & 19 & 48,786 & 19 & 856,148 \\
\hline Residun & 37 & 3,777 & 37 & 56,792 & 37 & 13,644 & 37 & 102,664 \\
\hline Linhagens & 19 & 42,995 & 19 & 92,849 & 19 & 53,334 & 19 & 408,048 \\
\hline Residuo & 37 & 1,974 & 37 & 28,870 & 35 & 14,252 & 35 & 42,744 \\
\hline Linhagens & 19 & 32,881 & 19 & 208,565 & 19 & 40,891 & 19 & 695,754 \\
\hline Residuo & 38 & 1,641 & 38 & 31,441 & 38 & 10,204 & 38 & 68,572 \\
\hline Linhagens & 19 & 24,821 & 19 & 107,194 & 19 & 9,730 & 19 & 86,912 \\
\hline Residuo & 19 & 2,584 & 19 & 19,610 & 19 & 4,288 & 19 & 31,491 \\
\hline
\end{tabular}

A sequência refere-se aos conjuntos 1, 2, 3, 4 e 5, respectivamente 
Tabela 7 - Resumo das análises de variâncias individuais para o cruzamento BR-80-14853 X PI-165896, para os caracteres: produção de grãos (PG), teor de óleo (TO), teor de proteína (TP) e acamamento (AC), para quatro conjuntos experimentais.

\begin{tabular}{|c|c|c|c|c|c|c|c|c|}
\hline \multirow[t]{2}{*}{ EV } & \multicolumn{2}{|r|}{$P G$} & \multicolumn{2}{|c|}{ TO } & \multicolumn{2}{|c|}{$\mathrm{TP}$} & \multicolumn{2}{|c|}{$A C$} \\
\hline & GL & QM & GL & $Q M$ & GL & $Q \mathrm{M}$ & GL & QM \\
\hline Linhagens & 19 & 9098,82 & 18 & 0,621 & 18 & 6,860 & 19 & 7,534 \\
\hline Residuo & 36 & 4754,76 & 18 & 0,156 & 18 & 8,513 & 37 & 0,574 \\
\hline Linhagens & 19 & 7653,16 & 17 & 0,586 & 17 & 4,803 & 19 & 3,946 \\
\hline Residuo & 33 & 5253,68 & 14 & 0,247 & 14 & 5,779 & 38 & 0,731 \\
\hline Linhagens & 19 & 11729,60 & 15 & 0,748 & 15 & 8,712 & 19 & 4,986 \\
\hline Residuo & 31 & 4349,06 & 13 & 0,240 & 12 & 7,681 & 38 & 0,936 \\
\hline Linhagens & 15 & 5288,14 & & & & & 17 & 3,907 \\
\hline Residuo & 12 & 1993,33 & & & & & 16 & 0,702 \\
\hline
\end{tabular}

A sequência refere-se aos conjuntos 1, 2, 3 e 4, respectivamente 
Tabela 8 - Resumo das análises de variâncias individuais para o cruzamento BR-80-14853 X PI-165896, para os caracteres: número de dias para $O$ florescimento $(D F)$, altura da planta no florescimento $(A F)$, número de dias para a maturação (DM) e altura da planta na maturação (AM), para quatro conjuntos experimentais.

\begin{tabular}{|c|c|c|c|c|c|c|c|c|}
\hline \multirow[t]{2}{*}{ EV } & \multicolumn{2}{|c|}{$\mathrm{DF}$} & \multicolumn{2}{|r|}{$A F$} & \multicolumn{2}{|c|}{ DM } & \multicolumn{2}{|r|}{$A M$} \\
\hline & GL & QM & GL & QM & GL & $Q M$ & GL & QM \\
\hline Iinhagens & 19 & 23,764 & 19 & 29,564 & 19 & 55,894 & 19 & 2654,169 \\
\hline Residuo & 38 & 1,843 & 38 & 36,133 & 37 & 8,548 & 37 & 80,993 \\
\hline Linhagens & 19 & 35,474 & 19 & 56,528 & 19 & 63,232 & 19 & 2510,994 \\
\hline Residuo & 38 & 1,945 & 38 & 37,390 & 38 & 10,126 & 38 & 110,427 \\
\hline Linhagens & 19 & 53,860 & 19 & 119,076 & 19 & 80,031 & 19 & 2043,811 \\
\hline Residuo & 38 & 3,407 & 38 & 32,250 & 38 & 11,957 & 38 & 164,283 \\
\hline Linhagens & 17 & 43,694 & 17 & 130,503 & 17 & 130,509 & 17 & 1636,253 \\
\hline Resíduo & 17 & 3,015 & 17 & 38,831 & 16 & 8,570 & 16 & 105,724 \\
\hline
\end{tabular}

A sequência refere-se aos conjuntos $1,2,3$ e 4, respectivamente 
Tabela 9 - Resumo das análises de variâncias individuais para o cruzamento BR-80-14853 X PI-239235, para os caracteres: produção de grãos (PG), teor de óleo (TO), teor de proteína (TP) e acamamento (AC), para quatro conjuntos experimentais.

\begin{tabular}{|c|c|c|c|c|c|c|c|c|}
\hline \multirow[t]{2}{*}{ EV } & \multicolumn{2}{|r|}{ PG } & \multicolumn{2}{|c|}{ TO } & \multicolumn{2}{|c|}{$\mathrm{TP}$} & \multicolumn{2}{|c|}{$\mathrm{AC}$} \\
\hline & GL & $\mathrm{QM}$ & GL & QM & GL & $\mathrm{QM}$ & GL & $\mathrm{QM}$ \\
\hline Linhagens & 19 & 12684,98 & 18 & 0,715 & 18 & 7,818 & 19 & 2,080 \\
\hline Residuo & 38 & 5725,20 & 16 & 0,112 & 16 & 6,946 & 38 & 0,632 \\
\hline Linhagens & 19 & 19245,58 & 18 & 0,890 & 18 & 4,200 & 19 & 1,364 \\
\hline Residuo & 37 & 5774,25 & 17 & 0,175 & 17 & 7,383 & 37 & 1,199 \\
\hline Linhagens & 18 & 13572,15 & 16 & 0,858 & 16 & 9,120 & 18 & 1,605 \\
\hline Residuo & 34 & 7400,49 & 15 & 0,410 & 15 & 6,658 & 35 & 1,066 \\
\hline Linhagens & 18 & 7185,79 & & & & & 18 & 3,010 \\
\hline Residuo & 33 & 7314,22 & & & & & 36 & 0,902 \\
\hline Linhagens & 16 & 13898,81 & & & & & 16 & 0,947 \\
\hline Residuo & 15 & 1728,76 & & & & & 15 & 0,531 \\
\hline
\end{tabular}

A sequencia refere-se aos conjuntos $1,2,3,4$ e 5, respectivamente 
Tabela 10 - Resumo das análises de variâncias individuais para o cruzamento BR-80-14853 X PI-239235, para os caracteres: número de dias para o florescimento $(D F)$, altura da planta no florescimento $(A F)$, número de dias para a maturação (DM) e altura da planta na maturação (AM), para quatro conjuntos experimentais.

\begin{tabular}{|c|c|c|c|c|c|c|c|c|}
\hline \multirow{2}{*}{ EV } & \multicolumn{2}{|c|}{$\mathrm{DE}$} & \multicolumn{2}{|r|}{$\mathrm{AF}$} & \multicolumn{2}{|c|}{$\mathrm{DM}$} & \multicolumn{2}{|r|}{$A M$} \\
\hline & GL & QM & GL & $Q M$ & GL & $Q M$ & GL & QM \\
\hline Linhagens & 19 & 105,350 & 19 & 781,659 & 19 & 10,536 & 19 & 1155,808 \\
\hline Residuo & 38 & 3,334 & 38 & 52,560 & 38 & 8,690 & 38 & 88,076 \\
\hline Linhagens & 19 & 46,559 & 19 & 257,437 & 19 & 18,734 & 19 & 198,554 \\
\hline Residuo & 37 & 3,289 & 37 & 59,869 & 37 & 5,170 & 37 & 65,969 \\
\hline Linhagens & 18 & 42,579 & 18 & 156,584 & 18 & 19,456 & 18 & 360,150 \\
\hline Residuo & 35 & 3,973 & 35 & 60,446 & 35 & 11,978 & 35 & 67,635 \\
\hline Linhagens & 18 & $5 b, 934$ & 18 & 451,259 & 18 & $12,34^{r} 7$ & 18 & 615,196 \\
\hline Residuo & 36 & 4,808 & 36 & 69,729 & 36 & 6,467 & 36 & 173,095 \\
\hline Iinhagens & 16 & 15,276 & 16 & 186,265 & 16 & 11,307 & 16 & 507,264 \\
\hline Residuo & 15 & 2,615 & 15 & 22,812 & 15 & 5,265 & 15 & 46,633 \\
\hline
\end{tabular}

A sequência refere-se aos conjuntos 1, 2, 3, 4 e 5, respectivamente 
Tabela 11 - Valores das médias populacionais $|x|$, para os caracteres produção de grãos (PG), teor de proteína (TP), teor de óleo (TO), número de dias para maturação (DM), altura da planta na maturação (AM), número de dias para o florescimento (DF), altura de plantas no florescimento (AF) e acamamento (AC), relativo às linhagens oriundas dos quatro cruzamentos: (1) OC-79230 X BR-80-8858, (2) BR-80-8858 $X$ BR-80-14853, (3) BR-80-14853 X PI-165896 e (4)BR80-14853 X PI-239235.

Caráter

Cruzamentos

(1)

(2)

(3)

(4)

\begin{tabular}{lrrrr}
\hline PG (g/parcela) & 211,18 & 255,92 & 178,28 & 221,46 \\
TP (8) & 39,58 & 39,92 & 39,48 & 39,73 \\
TO (8) & 22,25 & 21,34 & 21,50 & 21,07 \\
DM (dias) & 138,65 & 139,40 & 140,31 & 137,58 \\
AM (cm) & 71,56 & 76,76 & 88,10 & 87,83 \\
DF (dias) & 61,58 & 59,14 & 59,78 & 61,97 \\
AF (cm) & 62,28 & 63,40 & 56,84 & 67,35 \\
AC (nota) ${ }^{1}$ & 1,75 & 1,90 & 2,05 & 2,03 \\
\hline
\end{tabular}

1: Valores transformados para $\sqrt{x+1}$. 


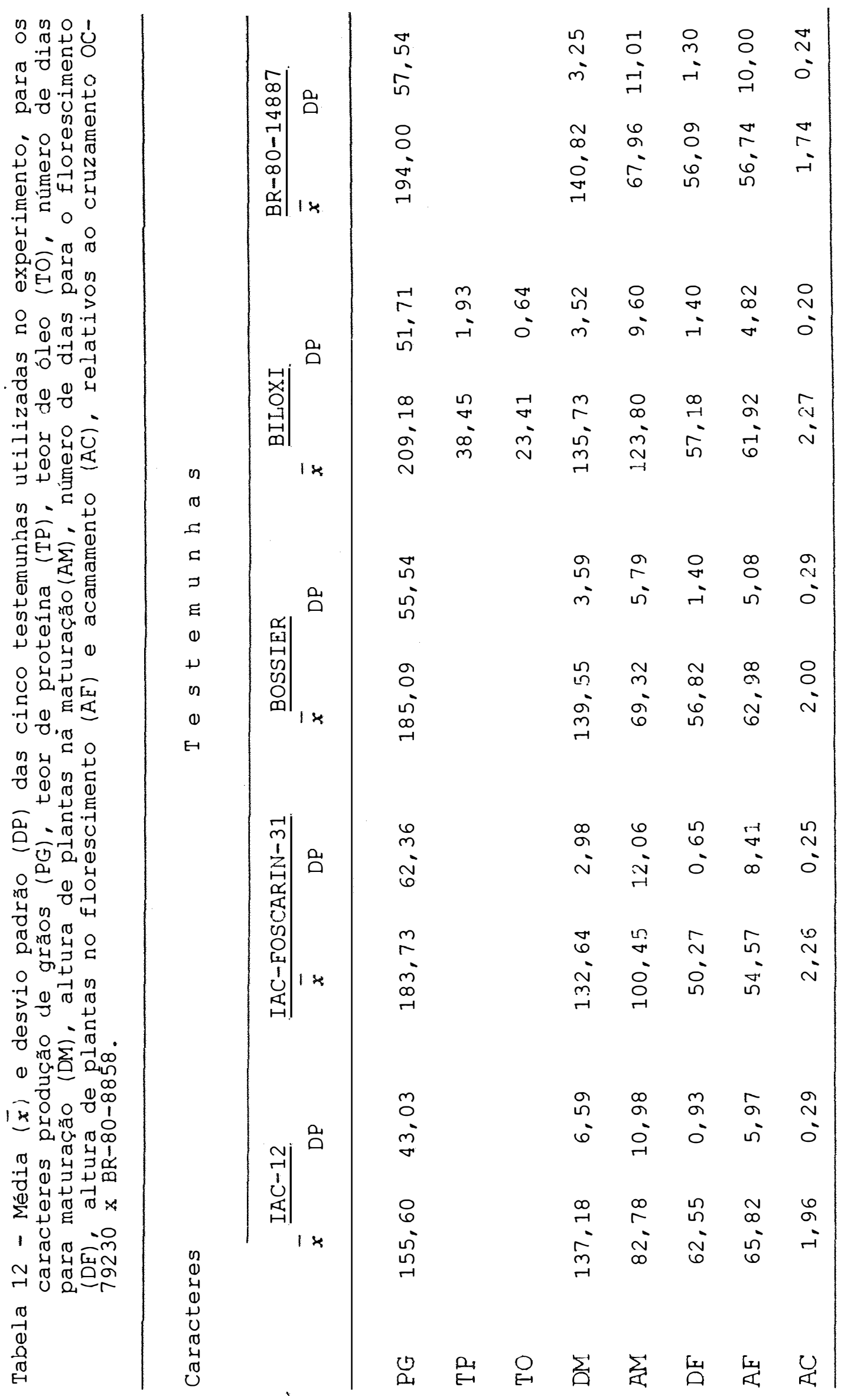




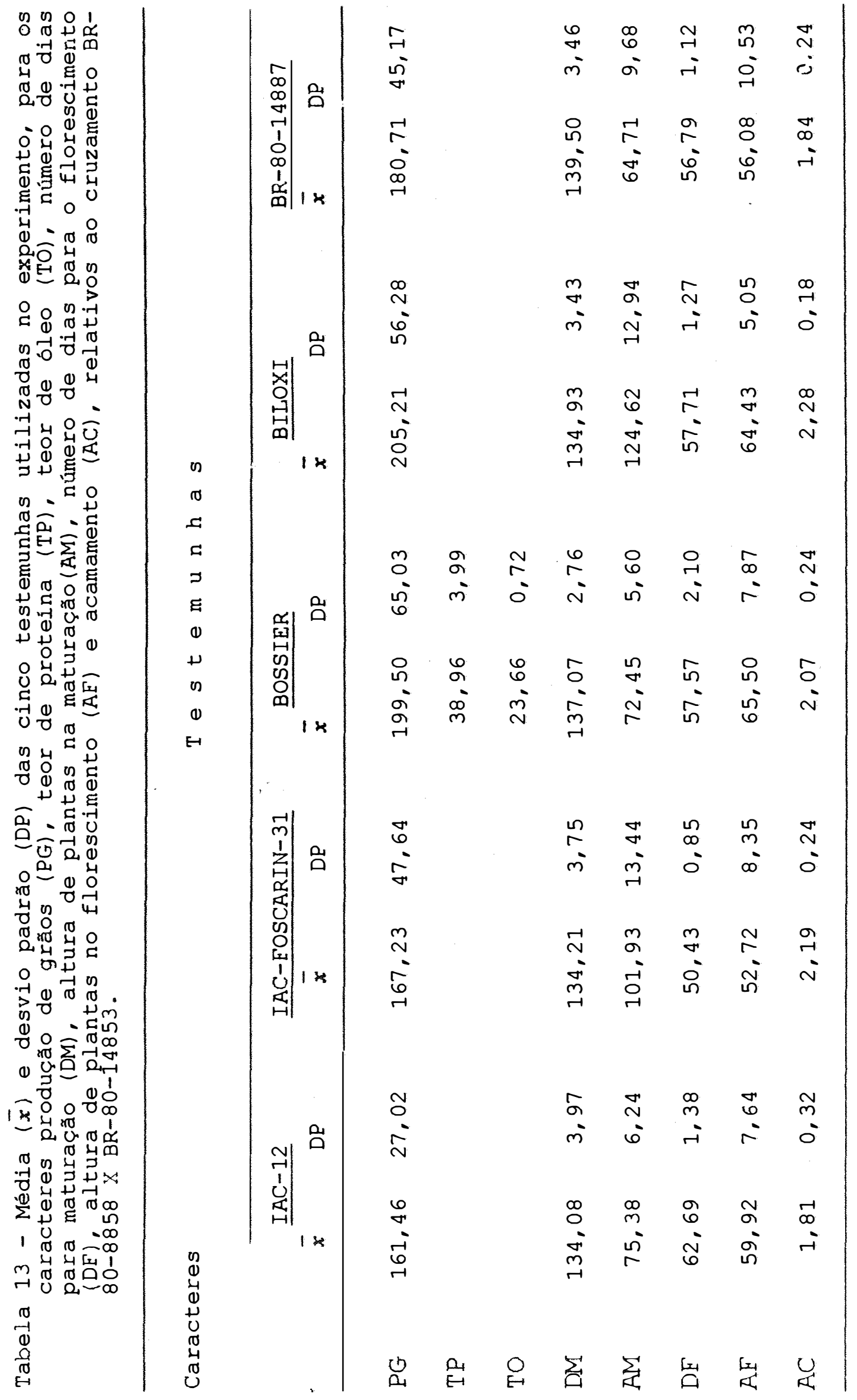




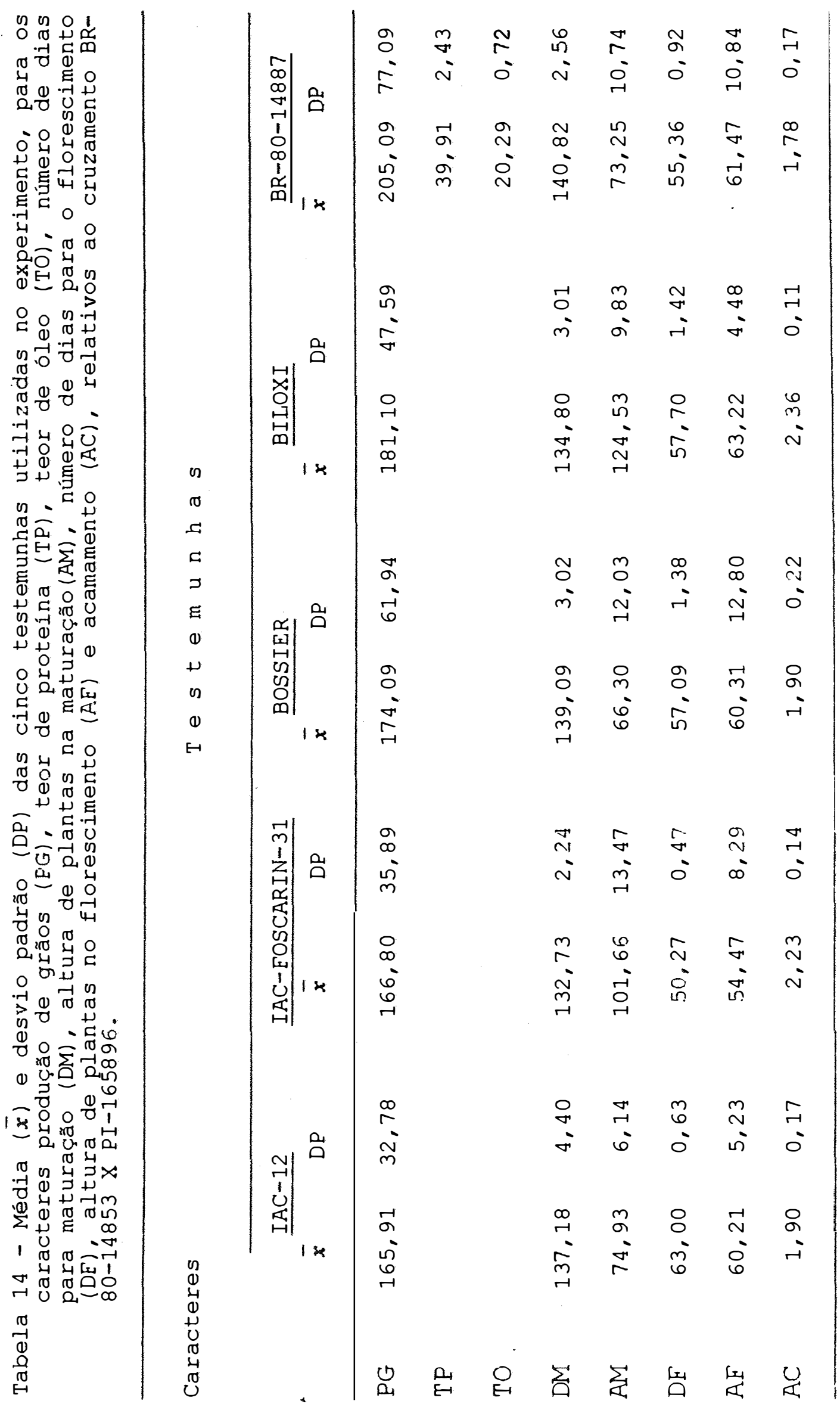




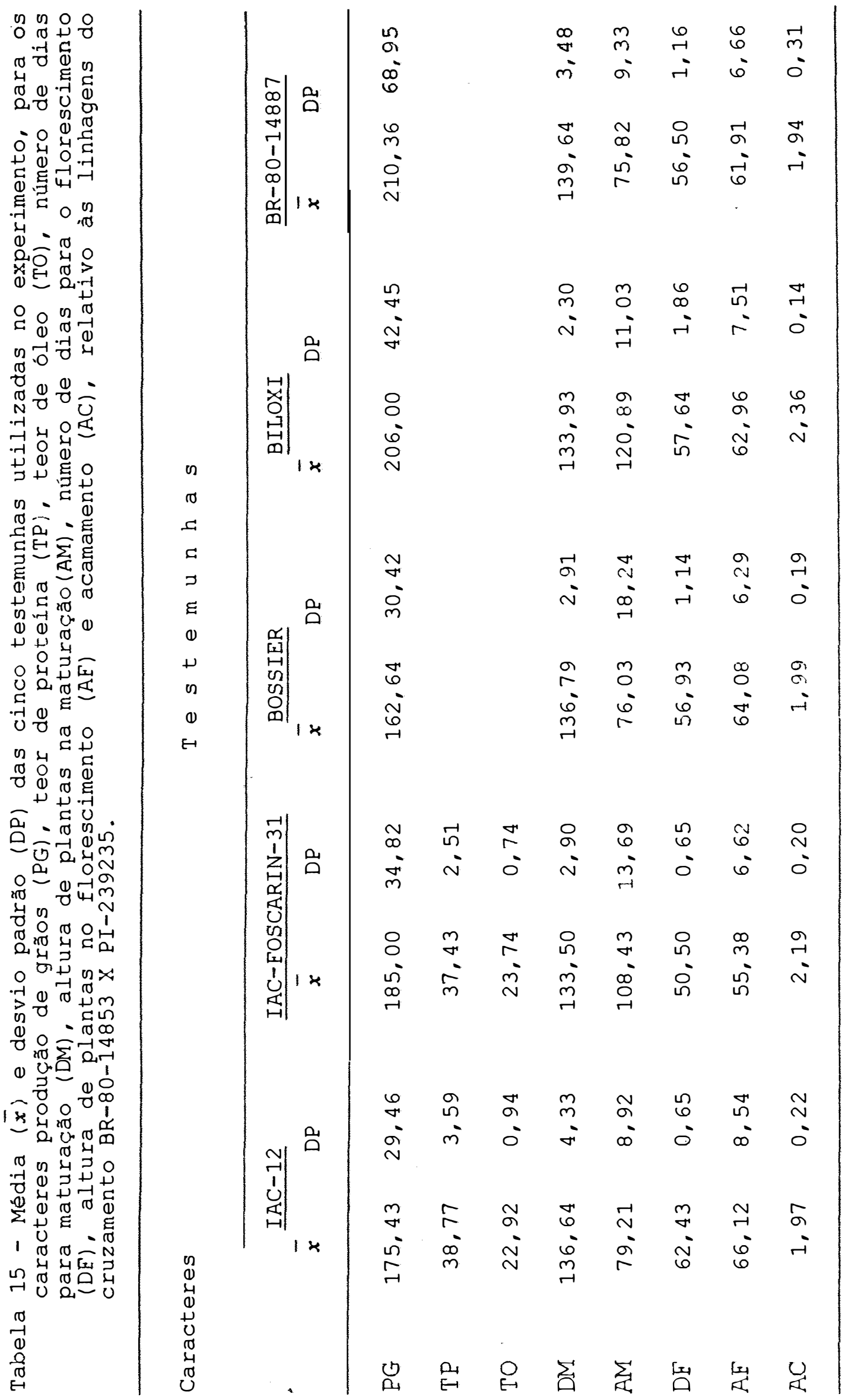


Tabela 16 - Valores e significâncias dos quadrados médios entre linhagens ( $\left.\mathrm{QM}_{\mathrm{L}}\right)$ e dos quadrados médios dos erros experimentais ( $\left(\mathrm{QM}_{E}\right)$, e seus respectivos graus de liberdade (GL), para os caracteres produção de grãos (PG), teor de proteína (TP), teor de óleo (TO), número de dias para maturação (DM), altura de plantas na maturação(AM), número de dias para o florescimento (DF), altura de plantas no florescimento $(A F)$ e acamamento $(A C)$, relativos ao cruzamento OC-79230 X BR-80-8858, para as análises combinadas.

Caracteres

GL

$\mathrm{QM}_{\mathrm{L}}$

$G_{E}$

QME

\begin{tabular}{lcccc}
\hline PG & 76 & $9357,620 * *$ & 127 & 3633,950 \\
TP & 57 & $8,855 * *$ & 52 & 3,432 \\
TO & 57 & $1,167 * *$ & 52 & 0,269 \\
DM & 76 & $56,430 * *$ & 131 & 9,210 \\
AM & 76 & $101,694 * *$ & 131 & 42,193 \\
DF & 76 & $82,240 * *$ & 132 & 2,500 \\
AF & 76 & $175,750 * *$ & 132 & 31,490 \\
AC & 76 & $0,066 n$ s & 131 & 0,048 \\
\hline ns: não significativo; & $* *$ significativo a 18. &
\end{tabular}


Tabela 17 - Valores e significâncias dos quadrados médios entre linhagens $\left(\mathrm{QM}_{L}\right)$ e dos quadrados médios dos erros experimentais $\left(\mathrm{QM}_{\mathrm{E}}\right)$, e seus respectivos graus de liberdade (GL), para os caracteres produção de grãos (PG), teor de proteína (TP), teor de óleo (TO), número de dias para maturação (DM), altura de plantas na maturação(AM), número de dias para $\circ$ florescimento ( $D F)$, altura de plantas no florescimento $(A F)$ e acamamento $(A C)$, relativos ao cruzamento BR-80-8858 X BR-80-14853, para as análises combinadas.

Caracteres

GLL

$\mathrm{QM}_{\mathrm{L}}$

GIE

$Q M_{E}$

\begin{tabular}{lcccr}
\hline PG & 95 & $14738,420 * *$ & 165 & 7309,41 \\
TP & 57 & $6,373 n s$ & 56 & 5,281 \\
TO & 57 & $0,725 * *$ & 56 & 0,390 \\
DM & 95 & $43,300 * *$ & 166 & 10,200 \\
AM & 95 & $453,686 * *$ & 166 & 80,139 \\
DF & 95 & $44,770 * *$ & 166 & 2,420 \\
AF & 95 & $159,500 \mathrm{~ns}$ & 169 & 553,970 \\
AC & 95 & $0,117 * *$ & 166 & 0,047 \\
\hline ns: não significativo; **: significativo a 18. &
\end{tabular}


Tabela 18 - Valores e significâncias dos quadrados médios entre linhagens $\left(\mathrm{CM}_{\mathrm{L}}\right)$ e dos quadrados médios dos erros experimentais $\left(\mathrm{QM}_{\mathrm{E}}\right)$, e seus respectivos graus de liberdade (GL), para os caracteres produção de grãos (PG), teor de proteína (TP), teor de óleo (TO), número de dias para maturação (DM), altura de plantas na maturação(AM), número de dias para $\circ$ florescimento (DF), altura de plantas no florescimento $(A F)$ e acamamento $(A C)$, relativos ao cruzamento BR-80-14853 X PI-165896, para as análises combinadas.

\begin{tabular}{|c|c|c|c|c|}
\hline Caracteres & $\mathrm{GL}_{\mathrm{L}}$ & $\mathrm{QM}_{\mathrm{L}}$ & $\mathrm{GL}_{\mathrm{E}}$ & $\mathrm{QM}_{E}$ \\
\hline $\mathrm{PG}$ & 72 & $8617,670 * *$ & 112 & 4493,600 \\
\hline $\mathrm{TP}$ & 50 & $6,716 n \mathrm{~s}$ & 44 & 7,416 \\
\hline TO & 50 & $0,647 * *$ & 45 & 0,209 \\
\hline$D M$ & 74 & $56,110 * *$ & 129 & 10,020 \\
\hline AM & 74 & $2226,850 * *$ & 129 & 117,270 \\
\hline$D F$ & 74 & $39,080 * *$ & 131 & 2,480 \\
\hline$A F$ & 74 & $82,660 * *$ & 131 & 35,720 \\
\hline$A C$ & 74 & $0,330 * *$ & 129 & 0,050 \\
\hline
\end{tabular}


Tabela 19 - Valores e significâncias dos quadrados médios entre linhagens $\left(\mathrm{QM}_{\mathrm{L}}\right.$ ) e dos quadrados médios dos erros experimentais ( $\left.\mathrm{QM}_{\mathrm{E}}\right)$, e seus respectivos graus de liberdade (GL), para os caracteres produção de grãos (PG), teor de proteína (TP), teor de óleo (TO), número de dias para maturação (DM), altura de plantas na maturação(AM), número de dias para 0 florescimento (DF), altura de plantas no florescimento (AF) e acamamento (AC), relativos ao cruzamento BR-80-14853 X PI-239235, para as análises combinadas.

Caracteres

$\mathrm{GL}_{\mathrm{L}}$

$\mathrm{QM}_{\mathrm{L}}$

GLE

${ }^{Q} M_{E}$

\begin{tabular}{lcccr}
\hline PG & 90 & $13126,950 * *$ & 157 & 6187,270 \\
TP & 52 & $6,966 n s$ & 48 & 7,011 \\
TO & 52 & $0,820 * *$ & 48 & 0,227 \\
DM & 90 & $14,560 * *$ & 161 & 7,770 \\
AM & 90 & $571,074 * *$ & 161 & 93,755 \\
DF & 90 & $54,330 * *$ & 161 & 3,820 \\
AF & 90 & $373,150 * *$ & 161 & 57,530 \\
AC & 90 & $0,116 * *$ & 161 & 0,060 \\
\hline ns: não significativo; **: significativo a 18. &
\end{tabular}




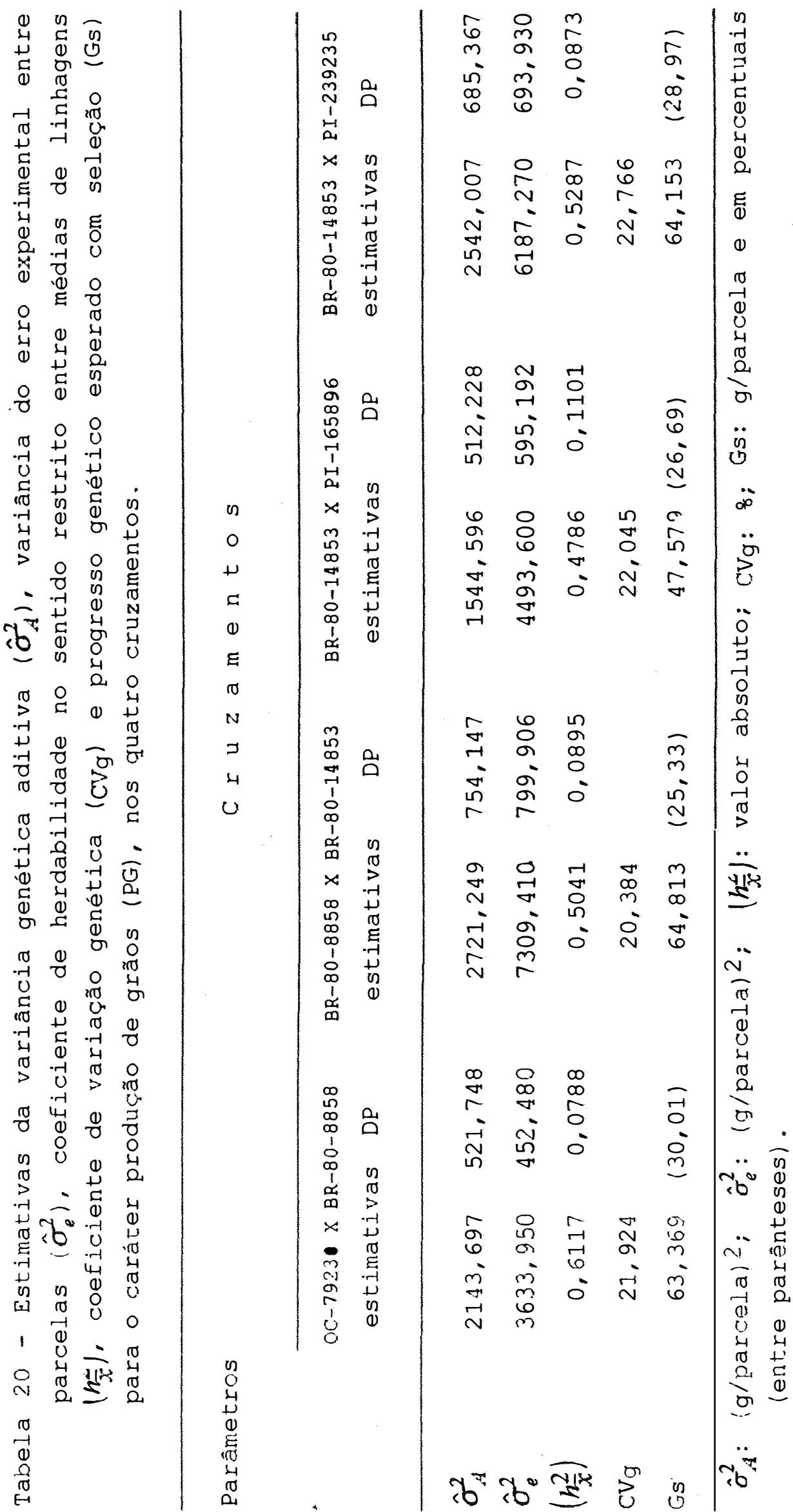




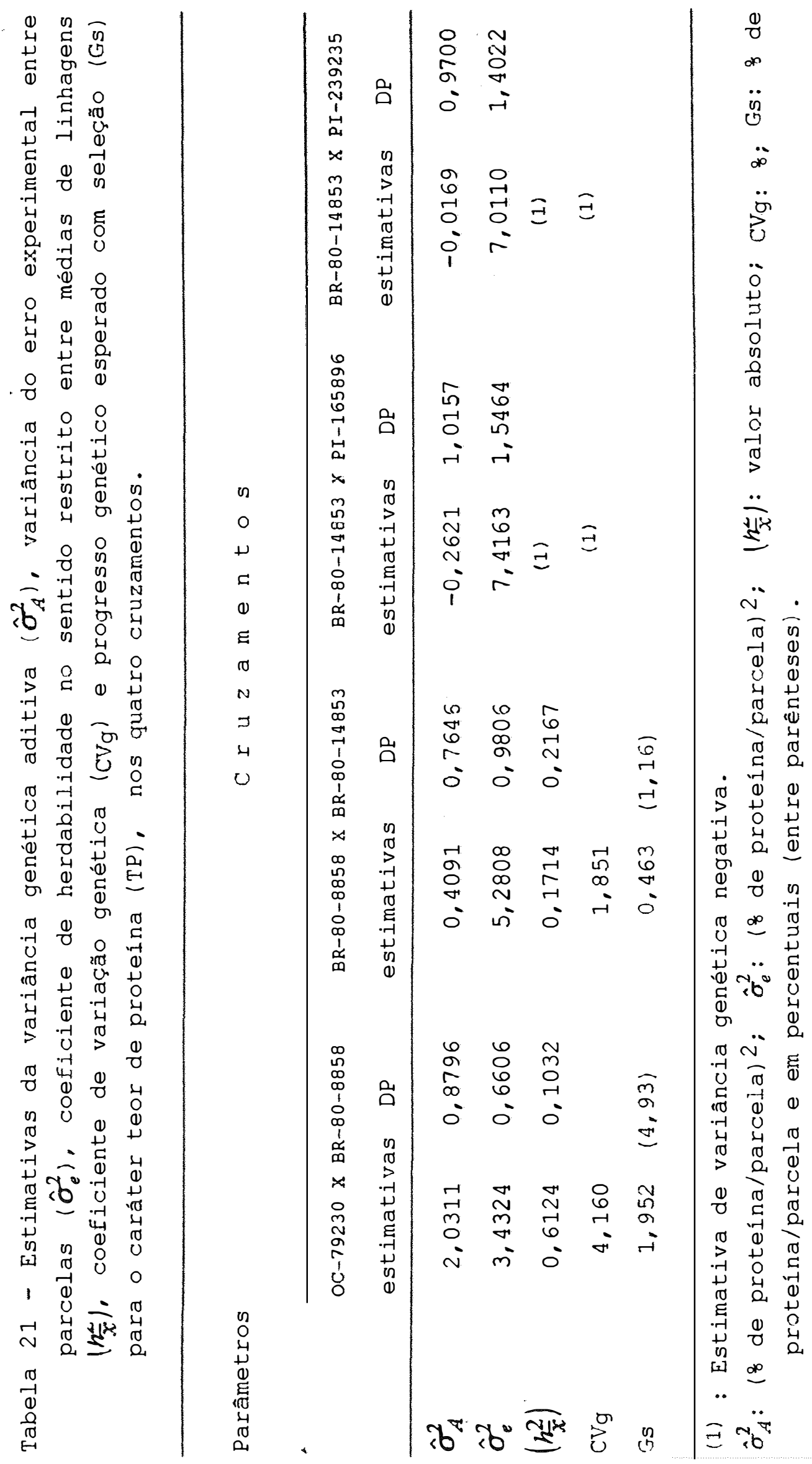




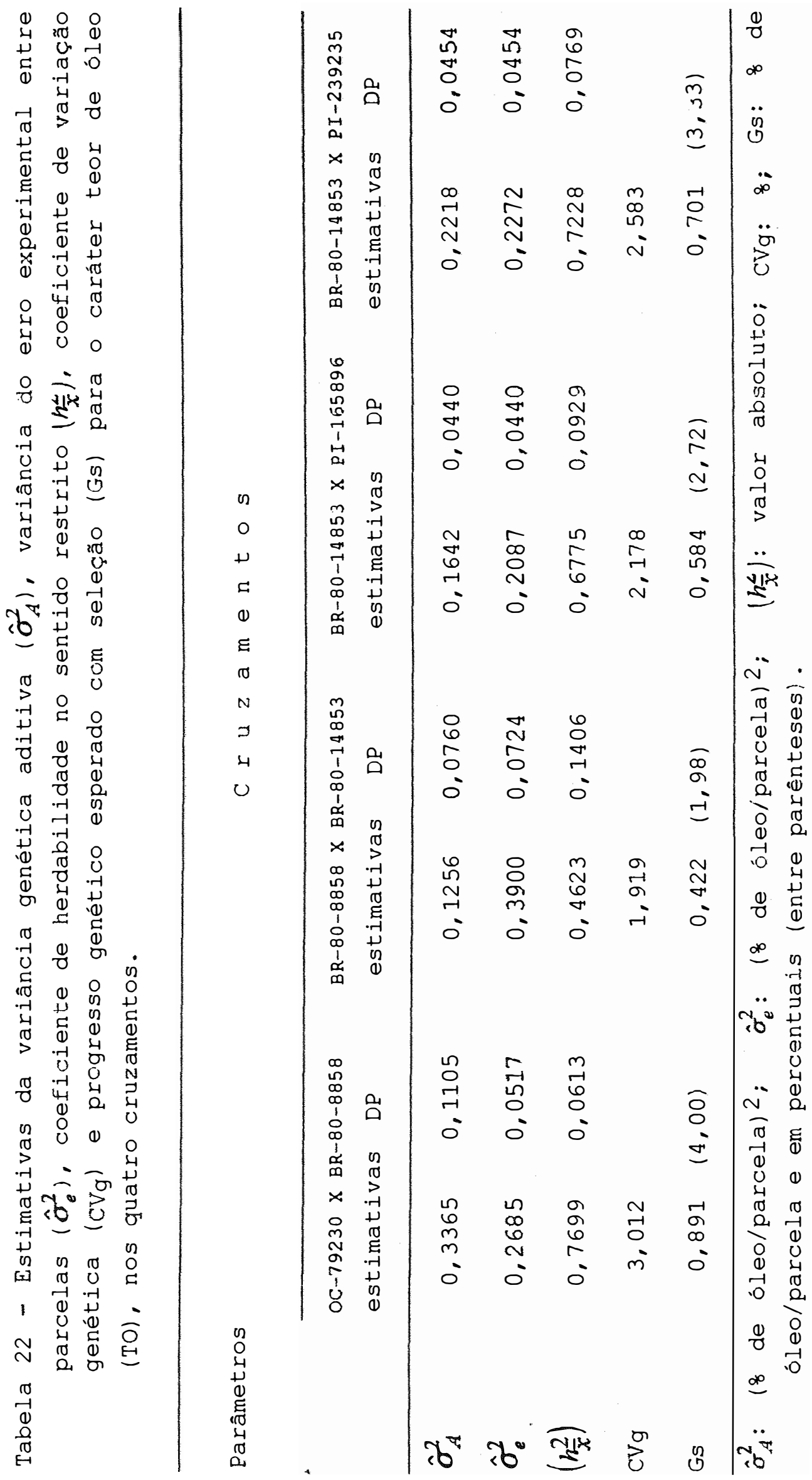




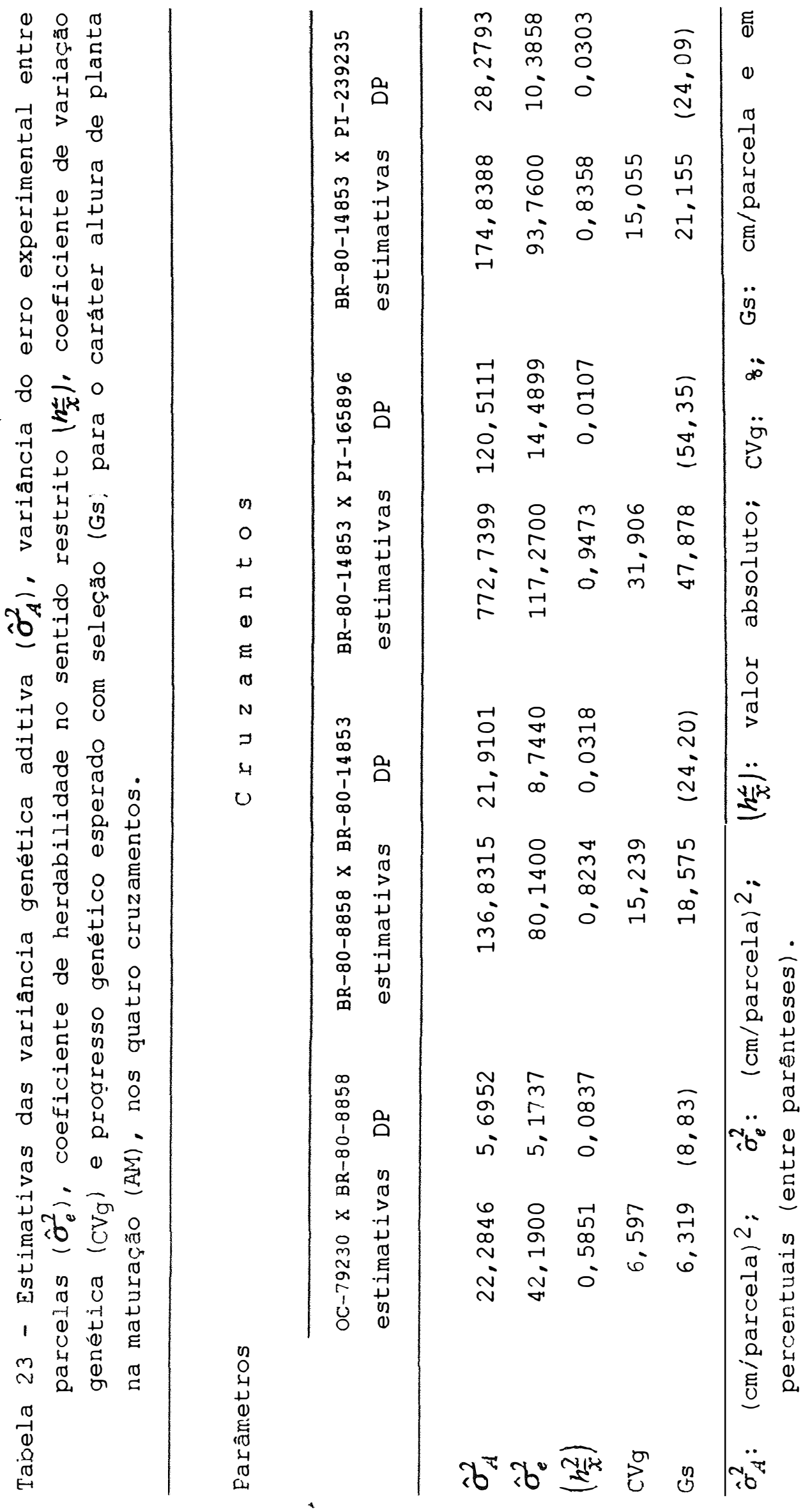




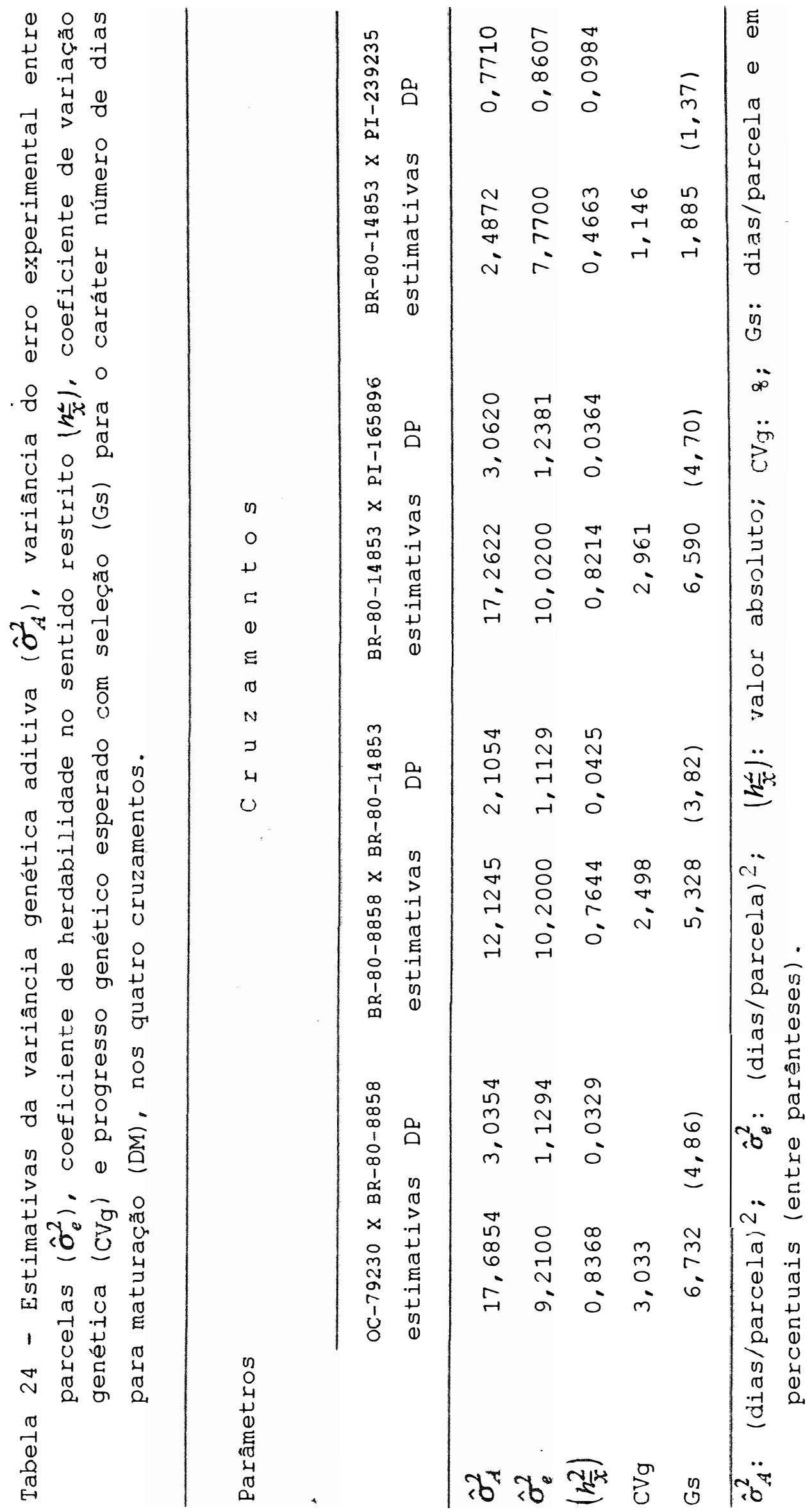




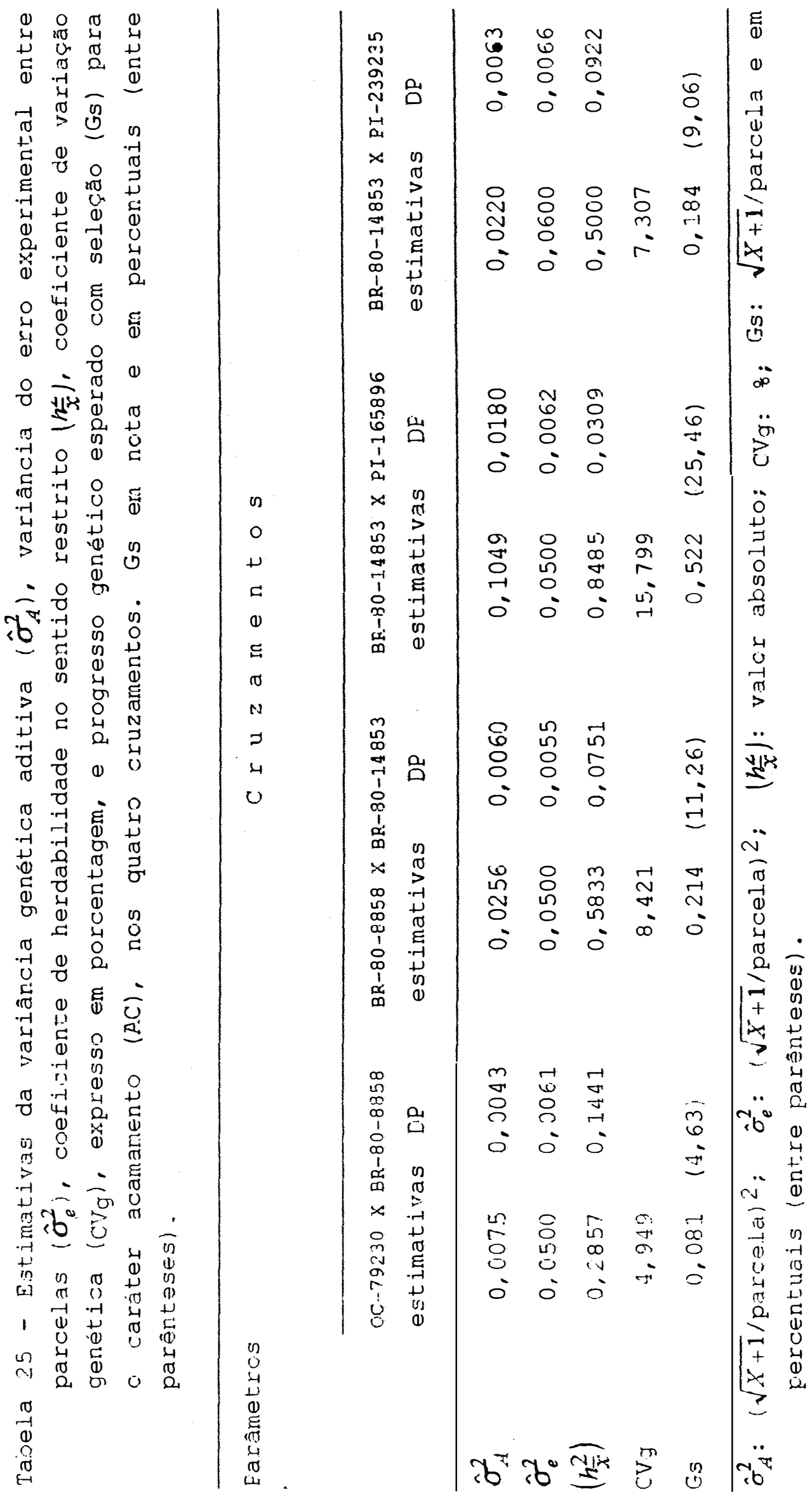




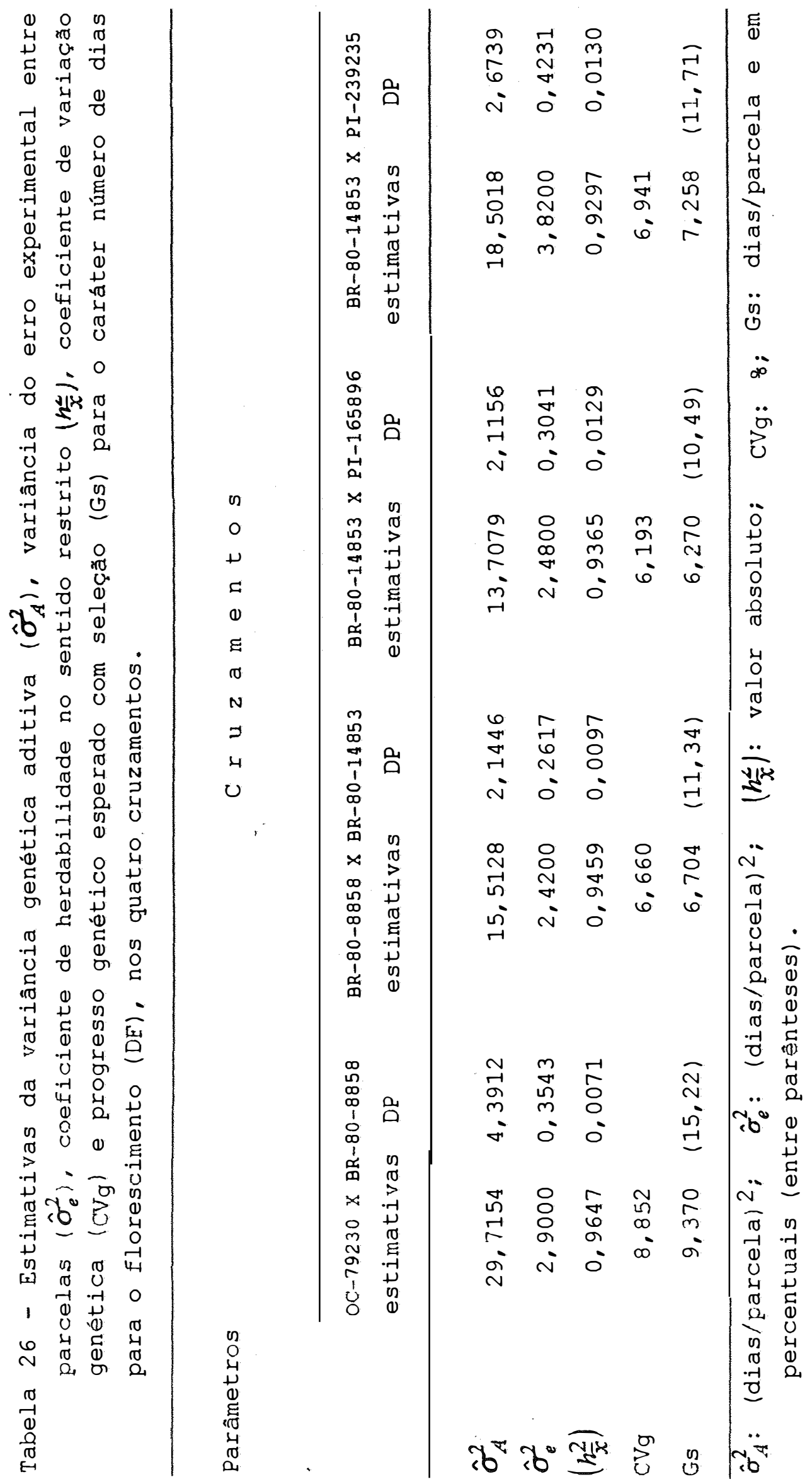




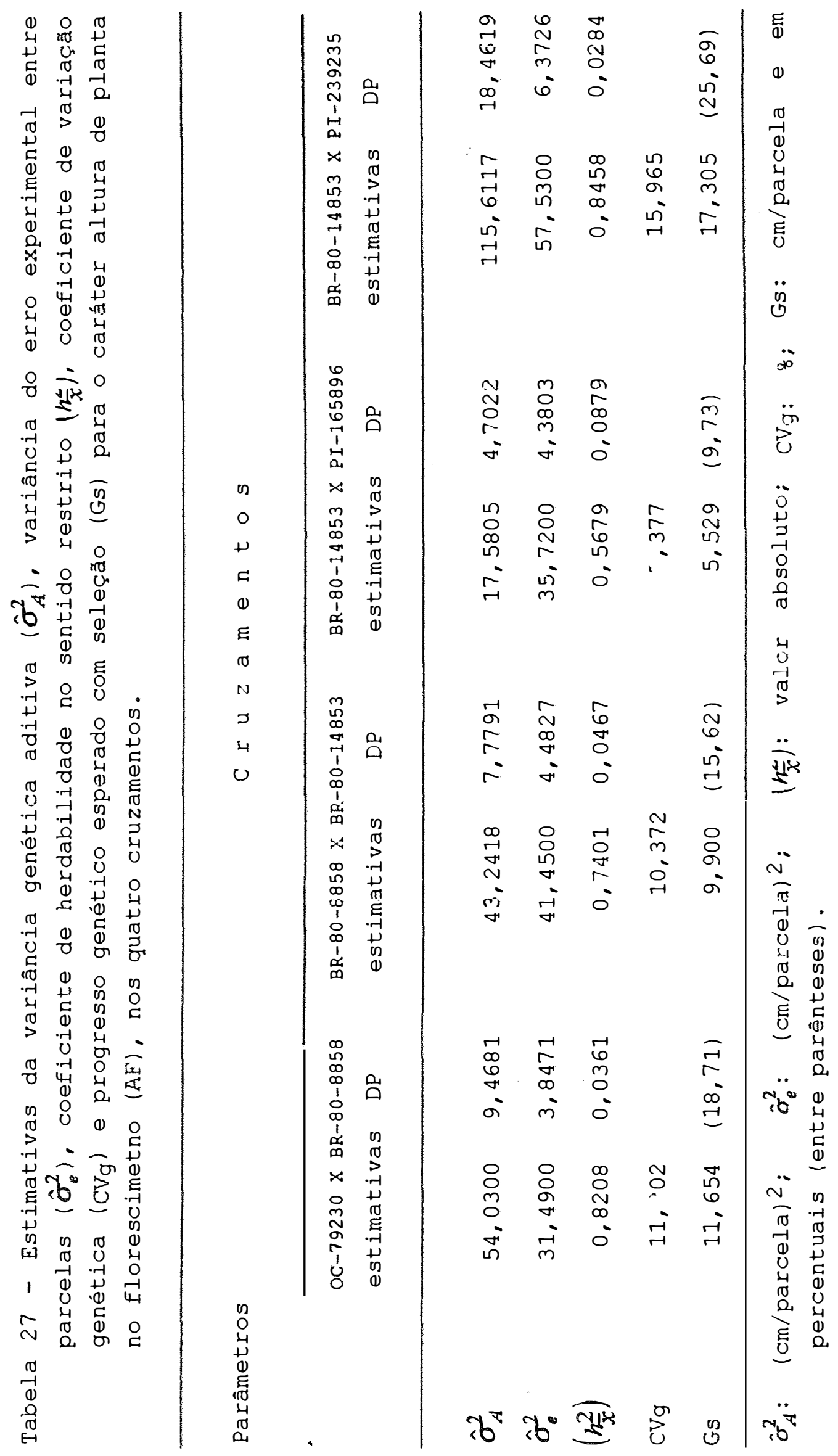


Tabela 28 - Produtos médios entre linhagens $\left(\mathrm{PM}_{\mathrm{L}}\right)$ e produtos médios do erro experimental ( $\left.\mathrm{PM}_{\mathrm{E}}\right)$, $\mathrm{Com}$ os seus respectivos graus de liberdade (GL) relativos ao cruzamento OC-79230 X BR-80-8858, para algumas combinações de caracteres:

\begin{tabular}{|c|c|c|c|c|c|c|}
\hline \multicolumn{3}{|c|}{ Combinações } & \multirow{2}{*}{$\frac{\mathrm{GL}_{\mathrm{L}}}{57}$} & \multirow{2}{*}{$\begin{array}{c}\mathrm{PM}_{\mathrm{L}} \\
76,525\end{array}$} & \multirow{2}{*}{$\begin{array}{r}\mathrm{GL}_{\mathrm{E}} \\
51\end{array}$} & \multirow{2}{*}{$\begin{array}{c}\mathrm{PM}_{E} \\
-15,648\end{array}$} \\
\hline$P G$ & $\mathrm{X}$ & $\mathrm{TP}$ & & & & \\
\hline PG & $\mathrm{x}$ & TO & 57 & $-18,720$ & 51 & $-9,623$ \\
\hline $\mathrm{TP}$ & $\mathrm{x}$ & TO & 57 & $-0,730$ & 52 & 0,184 \\
\hline$P G$ & $\mathrm{X}$ & DM & 76 & 335,133 & 127 & 28,321 \\
\hline PG & $\mathrm{X}$ & AM & 76 & 501,944 & 127 & 124,857 \\
\hline AC & $\mathrm{x}$ & AM & 76 & 0,714 & 131 & 0,114 \\
\hline
\end{tabular}

Tabela 29 - Produtos médios entre linhagens $\left(\mathrm{PM}_{\mathrm{I}}\right)$ e produtos médios do erro experimental ( $\mathrm{PM}_{\mathrm{E}}$ ), com os seus respectivos graus de liberdade (GL), relativos ao cruzamento BR-80-8858 X BR-80-14853, para algumas combinações de caracteres:

\begin{tabular}{|c|c|c|c|c|c|c|}
\hline \multicolumn{3}{|c|}{ Combinações } & \multirow{2}{*}{$\frac{\mathrm{GL}_{\mathrm{L}}}{57}$} & \multirow{2}{*}{$\begin{array}{c}\mathrm{PM}_{\mathrm{L}} \\
24,630\end{array}$} & \multirow{2}{*}{$\begin{array}{r}\text { GLE } \\
56\end{array}$} & \multirow{2}{*}{$\begin{array}{c}\mathrm{PME} \\
31,896\end{array}$} \\
\hline PG & $X$ & $\mathrm{TP}$ & & & & \\
\hline $\mathrm{PG}$ & $X$ & TO & 57 & 1,148 & 56 & $-4,174$ \\
\hline $\mathrm{TP}$ & $\mathrm{X}$ & TO & 57 & $-0,357$ & 56 & $-0,408$ \\
\hline$P G$ & $X$ & $\mathrm{DM}$ & 95 & 295,070 & 163 & 6,654 \\
\hline PG & $X$ & $A M$ & 95 & 593,506 & 163 & 124,566 \\
\hline$A C$ & $x$ & $A M$ & 95 & 3,506 & 163 & 0,111 \\
\hline
\end{tabular}


Tabela 30 - Produtos médios entre linhagens $\left(\mathrm{PM}_{\mathrm{L}}\right)$ e
produtos médios do erro experimental relativos ao cruzamento BR-80-14853 X PI-165896, para algumas combinações de caracteres:

\begin{tabular}{|c|c|c|c|c|c|c|}
\hline \multicolumn{3}{|c|}{ Combinações } & \multirow[t]{2}{*}{$\mathrm{GL}_{\mathrm{L}}$} & \multirow{2}{*}{$\begin{aligned} \mathrm{PM}_{\mathrm{L}} & \\
& (1)\end{aligned}$} & \multirow[t]{2}{*}{$\mathrm{GL}_{\mathrm{E}}$} & \multirow{2}{*}{$\begin{array}{r}\mathrm{PM}_{E} \\
(1)\end{array}$} \\
\hline$P G$ & $\mathrm{X}$ & $\mathrm{TP}$ & & & & \\
\hline$P G$ & $\mathrm{X}$ & TO & 50 & 16,011 & 44 & $-2,048$ \\
\hline $\mathrm{TP}$ & $\mathrm{x}$ & TO & & (1) & & (1) \\
\hline PG & $\mathrm{X}$ & $\mathrm{DM}$ & 72 & 345,448 & 111 & 34,731 \\
\hline $\mathrm{PG}$ & $\mathrm{X}$ & AM & 72 & 342,705 & 111 & 98,577 \\
\hline$A C$ & $\mathrm{X}$ & AM & 72 & 23,518 & 129 & 0,205 \\
\hline
\end{tabular}

(1): Estimativa da variância genética negativa.

Tabela 31 - Produtos médios entre linhagens ( $\mathrm{PM}_{\mathrm{L}}$ ) e produtos médios do erro experimental $\left\langle\mathrm{PM}_{\mathrm{E}}\right\rangle$, relativos ao cruzamento BR-80-14853 X PI-239235, para algumas combinações de caracteres:

\begin{tabular}{lrrrrr}
\hline Combinações & $\mathrm{GL}_{\mathrm{L}}$ & \multicolumn{1}{c}{$\mathrm{PM}_{\mathrm{L}}$} & $\mathrm{GL}$ & \multicolumn{1}{c}{$\mathrm{PM}_{\mathrm{E}}$} \\
\hline PG X & TP & & $(1)$ & & $(1)$ \\
PG X TO & 52 & 25,510 & 48 & 3,007 \\
TP X TO & & $(1)$ & & $(1)$ \\
PG X DM & 90 & $-17,554$ & 157 & 46,434 \\
PG X AM & 90 & $-123,218$ & 157 & 256,602 \\
AC X AM & 90 & 5,316 & 161 & 0,476 \\
\hline
\end{tabular}

(1): Estimativa da variância genética negativa. 
Tabela 32 - Estimativas das covariâncias genéticas ( $\left.\operatorname{COV}_{\mathrm{g}}\right)$ e das covariâncias ambientais $\left(\mathrm{COV}_{e}\right)$ relativos ao cruzamento OC-79230 X BR-80-8858, para algumas combinações de caracteres:

Combinações

$$
\mathrm{COV}_{\mathrm{g}} \quad \mathrm{COV}_{\mathrm{e}}
$$

$\begin{array}{lrlrr}\text { PG } & X & \text { TP } & 46,087 & -15,648 \\ \text { PG } & X & \text { TO } & -4,549 & -9,623 \\ \text { TP } & X & \text { TO } & -0,457 & 0,184 \\ \text { PG } & \text { X } & \text { DM } & 114,911 & 28,321 \\ \text { PG } & \text { X } & \text { AM } & 141,231 & 124,857 \\ \text { AC } & \text { X } & \text { AM } & 0,225 & 0,114\end{array}$

Tabela 33 -Estimativas das covariâncias genéticas ( $\operatorname{COV}_{\mathrm{g}}$ ) e das covariâncias ambientais (COVe) relativos ao cruzamento BR-80-8858 X BR-80-14853, para algumas combinações de caracteres:

\begin{tabular}{lcccc}
\hline Combinações & COV $_{g}$ & COV $_{e}$ \\
\hline PG X TP & $-3,633$ & 31,896 \\
PG & X & TO & 2,661 & $-4,174$ \\
TP & X & TO & 0,026 & $-0,408$ \\
PG X & DM & 105,647 & 6,654 \\
PG X AM & X & 171,773 & 124,566 \\
AC X & AM & 0,111 & 1,244
\end{tabular}


Tabela 34 - Estimativas das covarlâncias genéticas ( COV $_{\mathrm{g}}$ ) e das covariâncias ambientais (COVe) relativos ao cruzamento BR-80-14853 X PI-165896, para algumas combinações de caracteres:

Combinaçōes

$\mathrm{COV}_{\mathrm{g}} \quad \mathrm{COV}_{\mathrm{e}}$

PG $\quad X \quad T P$

PG $\quad X \quad$ TO

TP $\mathrm{X}$ TO

PG $\quad X \quad D M$

PG $X \quad A M$

$A C \quad X \quad A M$
(1)

9,030

(1)

116,373

91,434

8,731
(1)

$-2,048$

(1)

34,731

98,577

0,205

(1): Estimativa da variância genética negativa.

Tabela 35 -Estimativas das covariâncias genéticas $\left(\mathrm{COV}_{\mathrm{g}}\right)$ e das covariâncias ambientais ( $\left.\mathrm{COV}_{e}\right)$ relativos ao cruzamento BR-80-14853 X PI-239235, para algumas combinações de caracteres:

Combinações

$\mathrm{COV}_{\mathrm{g}} \quad \mathrm{COV}_{\mathrm{e}}$

PG $\quad X \quad T P$

(1)

PG $\quad X \quad T O$

TP $\quad \mathrm{X} \quad \mathrm{TO}$

11,252

(1)

PG $\quad X \quad D M$

$-23,439$

$-139,128$

1,773
(1)

3,007

46,434

256,602

0,476

(1): Estimativa da variância genética negativa. 
Tabela 36 - Estimativas dos coeficientes de correlação genética aditiva (rA), dos erros associados (DP) e dos coeficientes de correlação fenotípica $\left(r_{\bar{F}}\right)$, entre os caracteres estudados, relativos ${ }^{2}$ ao cruzamento OC-79230 x BR-80-8858.

Correlações

$r_{\mathrm{A}} \quad \mathrm{DP}$

$r_{\bar{F}}$

\begin{tabular}{lllrll}
\hline PG & $X$ & TP & 0,744 & 0,277 & $0,292 *$ \\
PG & $X$ & TO & $-0,179$ & 0,219 & $-0,197 \mathrm{~ns}$ \\
TP & $X$ & TO & $-0,414$ & 0,164 & $-0,227 \mathrm{~ns}$ \\
PG & $X$ & DM & 0,605 & 0,141 & $0,469 * *$ \\
PG & $X$ & AM & 0,654 & 0,185 & $0,516 * *$ \\
AC & $X$ & AM & 0,580 & 0,284 & $0,276 *$
\end{tabular}

ns: nåo significativo; *: significativo a $58 ;{ }^{* *}$ : significativo a 18 .

Tabela 37 - Estimativas dos coeficientes de correlação genética aditiva ( $r_{A}$ ), dos erros associados (DP) e dos coeficientes de correlação fenotípica $\left(r_{\bar{F}}\right)$, $\begin{array}{ll}\text { entre os caracteres } & \text { estudados, } \\ \text { cruzamento } & \text { BR-80-8858 X BR-80-14853. }\end{array}$

\begin{tabular}{lcccc}
\hline Correlações & $r_{\mathrm{A}}$ & DP & $r_{\bar{F}}$ \\
\hline PG X TP & $-0,083$ & 0,503 & $0,084^{\mathrm{ns}}$ \\
PG X TO & 0,108 & 0,270 & $0,012^{\mathrm{ns}}$ \\
TP X TO & 0,084 & 0,531 & $-0,166^{\mathrm{ns}}$ \\
PG X DM & 0,571 & 0,147 & $0,366^{* *}$ \\
PG X AM & 0,281 & 0,139 & $0,231^{\mathrm{ns}}$ \\
AC X AM & 0,669 & 0,128 & $0,481^{* *}$
\end{tabular}

ns: não significativo; *: significativo a $58 ;{ }^{* *}$ : significativo a $1 \frac{8}{8}$. 
Tabela 38 - Estimativas dos coeficientes de correlação genética aditiva (rA), dos erros associados (DP) e dos coeficientes de correlação fenotípica $\left(r_{\bar{F}}\right)$, entre os caracteres estudados, relativos ao cruzamento BR-80-14853 X PI-165896.

Correlações

rA

DP

$r_{\bar{F}}$

$P G \quad X \quad T P$

(1)

(1)

PG $\quad X \quad$ TO

0,780

0,389

$0,247^{\text {ns }}$

TP X TO

(1)

$P G \quad X \quad D M$

0,718

0,165

$0,506 * *$

PG $\quad X \quad A M$

0,084

0,144

$0,081^{n s}$

AC $X \quad A M$

0,961

0,108

$0,870 * *$

(1): Estimativa da variância genética negativa.

ns: não significativo; *: significativo a $5 \%$; ** significativo a 1 \% .

Tabela 39 - Éstimativas dos coeficientes de correlação genética aditiva ( $r A$ ), dos erros associados (DP) e dos coeficientes de correlação fenotipica $\left(r_{\bar{F}}\right)$, entre os caracteres estudados, relativos ao cruzamento BR-80-14853 X PI-239235.

\begin{tabular}{|c|c|c|c|c|c|}
\hline \multicolumn{3}{|c|}{ Correlações } & \multirow{2}{*}{$\frac{r_{A}}{(1)}$} & \multirow{2}{*}{$\begin{array}{l}\mathrm{DP} \\
\text { (1) }\end{array}$} & \multirow{2}{*}{$\frac{r_{\bar{F}}}{(1)}$} \\
\hline$P G$ & $\mathrm{X}$ & $\mathrm{TP}$ & & & \\
\hline$P G$ & $\mathrm{X}$ & TO & 0,403 & 0,214 & $0,265 \mathrm{~ns}$ \\
\hline $\mathrm{TP}$ & $\mathrm{X}$ & TO & (1) & (1) & (1) \\
\hline$P G$ & $\mathrm{X}$ & $\mathrm{DM}$ & $-0,286$ & 0,206 & $-0,040 \mathrm{~ns}$ \\
\hline$P G$ & $\mathrm{X}$ & $A M$ & $-0,211$ & 0,139 & $-0,046 \pi \mathrm{s}$ \\
\hline$A C$ & $\mathrm{X}$ & $A M$ & 0,928 & 0,145 & $0,653 * *$ \\
\hline
\end{tabular}

